\title{
User involvement in the development of patient decision aids:
}

\section{A systematic review}

AUTHORS: Gratianne Vaisson, MSc ${ }^{1}$; Thierry Provencher, $\mathrm{BA}^{1}$; Michèle Dugas, $\mathrm{MSc}^{1}$; MarieÈve Trottier, $\mathrm{MSc}^{1}$; Selma Chipenda Dansokho, $\mathrm{PhD}^{1}$; Heather Colquhoun, $\mathrm{PhD}^{2}$; Angela Fagerlin, $\mathrm{PhD}^{3}$; Anik M. C. Giguere, $\mathrm{PhD}^{1,4,5}$; Hina Hakim, MSc ${ }^{1}$; Lynne Haslett, NP-PHC, MEd $d^{6}$; Aubri S. Hoffman, $\mathrm{PhD}^{7}$; Noah M. Ivers, MD PhD ${ }^{8}$; Anne-Sophie Julien, MSc ${ }^{9}$; France Légaré, MD PhD ${ }^{1,4,5,9}$; Jean-Sébastien Renaud, PhD ${ }^{1,4}$; Dawn Stacey, RN PhD ${ }^{10}$; Robert J. Volk, PhD ${ }^{7}$; Holly O. Witteman, $\mathrm{PhD}^{1,4,5,9}$

${ }^{1}$ Office of Education and Professional Development, Faculty of Medicine, Laval University, Quebec City, QC, Canada

${ }^{2}$ Department of Occupational Science and Occupational Therapy, Faculty of Medicine, University of Toronto, Toronto, Ontario, Canada

${ }^{3}$ Department of Population Health Sciences, University of Utah, Salt Lake City, Utah, USA

${ }^{4}$ Department of Family and Emergency Medicine, Faculty of Medicine, Laval University, Quebec City, Quebec, Canada

${ }^{5}$ Primary Care Research Centre of Laval University (Centre de recherche sur les soins et les services de première ligne de l'Université Laval, CERSSPL-UL), Quebec City, QC, Canada ${ }^{6}$ East End Community Health Centre, Toronto, Ontario, Canada

${ }^{7}$ Department of Health Services Research, The University of Texas MD Anderson Cancer Center, Houston, Texas, USA

${ }^{8}$ Family Practice Health Centre, Institute for Health Systems Solutions and Virtual Care and Women's College Research Institute, Women's College Hospital, Toronto, Ontario, Canada ${ }^{9}$ Research Center of the Laval University Academic Medical Centre (Centre de recherche du CHU de Québec-Université Laval), Quebec City, QC, Canada

${ }^{10}$ School of Nursing and Ottawa Hospital Research Institute, University of Ottawa, Ottawa, Ontario, Canada

Corresponding author: Holly O. Witteman, 1050 avenue de la Médecine, Pavillon FerdinandVandry, Université Laval, Québec City, Québec, G1V 0A6, Canada, telephone: 418.656.2131 x3981, fax: 418-656.2465, email: holly.witteman@fmed.ulaval.ca

Running title: User involvement in patient decision aid development

Word count: 5385 


\section{Abstract (350/350 words)}

Background: Multiple guidelines recommend involving patients and stakeholders in developing patient decision aids; however, best practices have yet to be identified. User-centered design is a well-established approach for engaging users in developing tools. We aimed to compile reports of patient decision aid development, using a user-centered design framework to synthesize evidence of existing practices and identify potential opportunities for improvement.

Methods: We conducted searches in MEDLINE, EMBASE, PubMed, Web of Science, the Cochrane Library, the ACM library, IEEE Xplore and Google Scholar. We included articles describing (1) at least one development step of a patient decision aid, (2) at least one development step of user- or human-centered design of another patient-centered tool, and/or (3) evaluation of included decision aids and other patient-centered tools. Two analysts independently screened for inclusion, assessed study quality, and extracted data.

Results: We included 623 articles describing 390 projects: 325 patient decision aid projects and 65 user-centered design projects. Fifty percent of patient decision aid projects reported involving users in at least one development step for understanding users, 35\% in at least one development step for developing/refining the prototype and $84 \%$ in at least one development step for directly or indirectly observing prospective users' interaction with the prototype. Usercentered design projects reported $91 \%, 49 \%$ and $92 \%$, respectively. Seventy-four percent of patient decision aid projects reported iterative development processes with median 3 development cycles (interquartile range 2-4); $92 \%$ of user-centered design projects reported iterativity, with median 3 development cycles (interquartile range 2-3). Sixty-six percent of patient decision aid projects and $89 \%$ of user-centered design projects reported preliminary evaluations such as usability testing or feasibility testing.

Conclusions: We identified 3 key opportunities for improving the user-centeredness of patient decision aid development: involving users earlier to understand their needs, goals, strengths, limitations, context and intuitive processes; asking about and observing users' interactions with developing versions of the decision aid; and reporting changes between iterative cycles. Additionally, developers of patient decision aids and other patient-centered tools may wish to more often involve patients, clinicians and other users in co-design of prototypes and in formal advisory or partnership roles. 


\section{Main Text}

\section{Introduction}

Patient decision aids are key tools for supporting shared decision making, a practice described as "the pinnacle of patient-centered care" [1] and advocated as a solution to the "silent misdiagnosis" of patient preferences [2]. These tools make health decisions explicit, provide balanced information on benefits and harms of options, and help people clarify what matters to them in their own context and circumstances.

Patient decision aids are intended to complement counselling from a healthcare professional in order to help people make evidence-informed, values-congruent health decisions. Their growing number [3] and legislative power [4] are precursors of their probable ever-increasing development. Yet little is known about how to best engage users of patient decision aids in their development. There is interest in and enthusiasm for participatory approaches such as usercentered design, but little evidence to guide practice.

User-centered design is a well-established approach that has been used to develop products, services, systems [5-9], including patient-centered tools [10-13]. Examples of tools developed using this approach range from programs inciting good health habits like smoking and alcohol cessation $[14,15]$ to Internet-based support systems for self-management of chronic diseases [16-18] and computer interfaces adapted for people with severe motor paralysis $[19,20]$.

User-centered design involves an iterative method of involving prospective users in repeated cycles of development. Our framework, as shown in Figure 1, synthesizes seminal literature [5,7,9,21-23] and defines three elements in each iterative cycle: (1) understanding users, their needs and their environment, (2) developing/refining the prototype, and (3) observing the users interacting with the prototype. Each of these elements can include multiple methodological steps and the process as a whole may be reported across multiple papers. 
Figure 1. User-centered design framework and associated development steps.

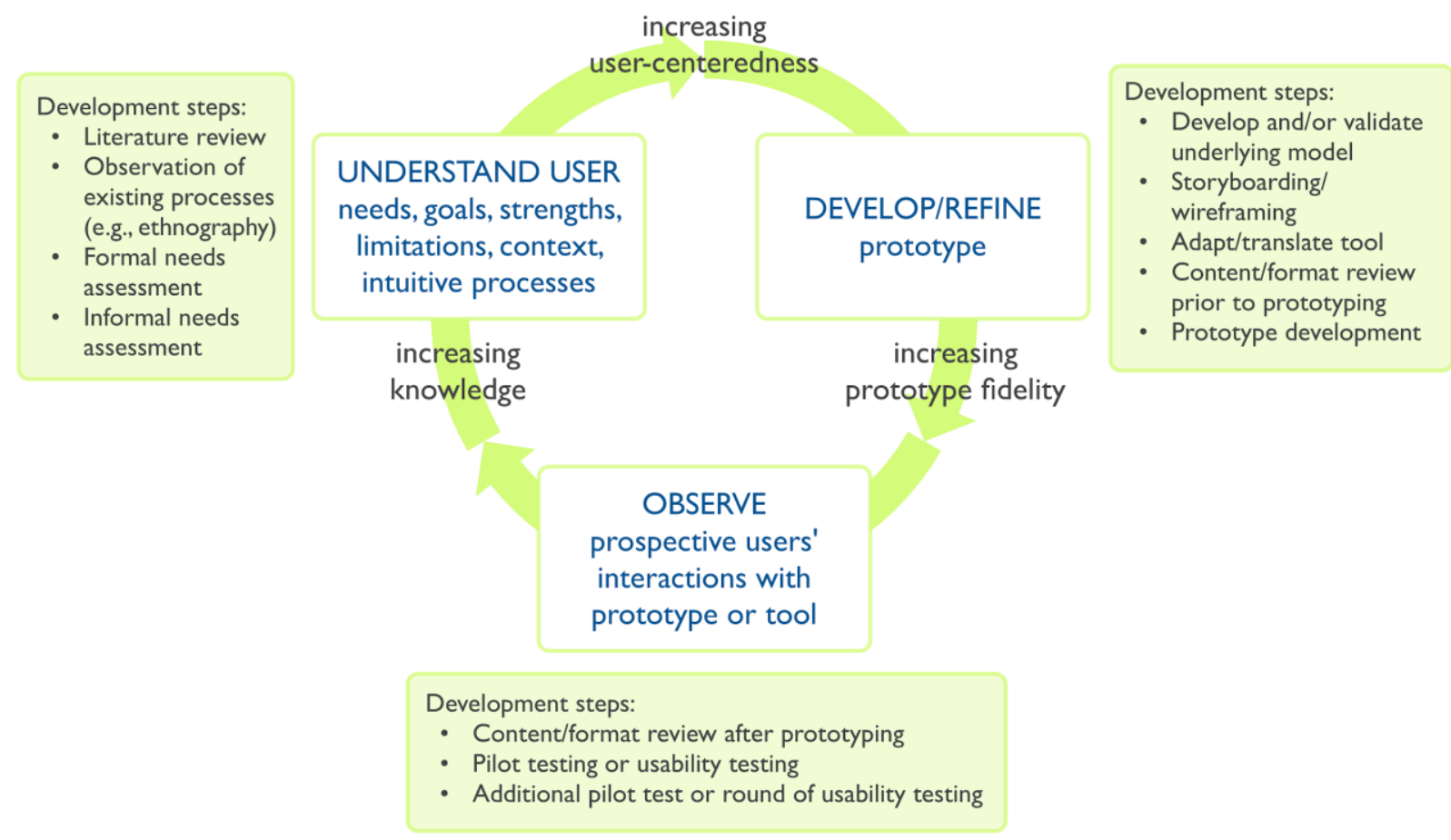

In this systematic review, we aimed to synthesize the published development processes of patient decision aids and to situate these in the context of a framework of user-centered design [24]. Herein, we describe the development processes of patient decision aids and, for context, also describe the development processes of other patient-centered tools that explicitly named user-centered or human-centered design as their guiding model.

\section{Methods}

The overall study design included synthesizing published articles describing the development process of a patient decision aid and articles describing the user-centered development of a patient-centered tool. We report this review according to PRISMA guidelines. (See PRISMA checklist in Appendix 4.)

\section{Protocol and registration}

We previously registered this review in PROSPERO

(http://www.crd.york.ac.uk/PROSPERO/display_record.asp?ID=CRD42014013241) and published the protocol describing our systematic review methodology [24].

\section{Eligibility criteria}

We identified articles that describe at least one development step and/or any type of evaluation of a patient decision aid intended to support a personal health decision, or that explicitly used 
one of the four terms 'user-centered design', 'user-centred design', 'human-centered design' or 'human-centred design' to develop a patient-centered health-related tool (e.g., tools for education, social support, or self-management). We excluded articles that applied user-centered design to tools solely intended for clinicians. We also screened additional articles suggested by authors of included articles when we contacted them to validate the data we extracted from their article(s). No language or date restrictions were applied for any searches.

\section{Information sources and search}

Our search strategy expanded slightly from our initial plans. Between April 30, 2014 and May 11, 2014, we conducted initial database searches for articles describing patient decision aid development and evaluation. On September 29, 2014, we searched for articles describing usercentered design projects. We had assumed that any randomized controlled trials of patient decision aids would not need to be identified again, as they would already have been captured in the Cochrane review of patient decision aids available at the time [25]. However, because the Cochrane review included patient decision aids that addressed screening or treatment decisions but not other decisions, we re-screened articles excluded from the 2014 Cochrane review. We then replicated Stacey and colleagues' search strategy for randomized controlled trials on July 9,2015 , using nearly the same inclusion and exclusion criteria except that we sought articles describing other types of decisions. Our originally-planned search strategy did not include evaluation of user-centered design projects. This created an imbalance in which we captured more publications describing the evaluation of patient decision aids. To rectify this, on June 20, 2017, we used Google Scholar to search for articles describing the evaluation of the tools developed in user-centered design projects by searching for articles that cited the included papers for user-centered design projects. All search strategies were developed by an information specialist (WW) and peer-reviewed by an independent information specialist (ME, MF, see Acknowledgments). Appendix 1 provides full details of all search strategies.

\section{Study selection}

We conducted the screening process in accordance with standard methods for systematic reviews [26]. After a training period where all screeners practiced on randomly-selected subsets of search results, pairs of independent screeners reviewed each title and abstract for inclusion or exclusion. Once all of the articles had been screened by title and abstract, we obtained the full text of retained articles for screening by two independent reviewers, who divided them into three categories: include and retain for data extraction, retain for a screen of the references but do not include for data extraction, and exclude. At all stages of screening, if the two independent screeners disagreed and were unable to come to agreement in discussion, a third person adjudicated to determine if the article should be included for further screening.

\section{Data extraction}

Based on our conceptual framework of user-centered design and with reviews among authors of this paper and 15 additional experts in the field, we created and iteratively revised our extraction form with 4 cycles of testing (See Appendix 2: Data extraction form). Throughout the data 
extraction process, when a field allowed the option to indicate 'Other', we created new categories from this open text whenever there were at least 10 occurrences of a response.

Trained pairs of data analysts extracted data from each included article using this standardized form [24]. Lack of agreement was resolved through discussion with the team until consensus was reached.

We extracted key factors grounded in our conceptual framework of user-centered design. Data presented in this paper include: (1) what steps were conducted as part of development, (2) whether patients and other stakeholders were involved in the development and, if yes, (3) who they were (e.g., people who had previously faced the issue, people who might potentially face this issue, patients who were actually facing this issue, caregivers, clinicians who were not part of the research team), (4) how they were identified and recruited, and (5) how many were recruited; (6) whether there were iterative cycles of consultation, and, if yes, (7) how many cycles, (8) at what point(s) in the process were they involved, and (9) what their involvement consisted of (i.e., were they observed interacting with the decision aid in a naturalistic fashion or were they asked to speculate on how they might use it); and (10) types of feedback sought (i.e., comprehensiveness or appropriateness of content, format, other), and (11) how their feedback was incorporated into the design. We also extracted secondary data about whether or not each article cited a relevant guideline, theory or framework. In addition, from articles describing the evaluation of a tool, we extracted information about the type of evaluation, including whether or not outcomes such as feasibility, acceptability, and usability were reported.

For each article, two trained reviewers extracted and reconciled all data. If consensus could not be reached, a third trained reviewer adjudicated the disagreement, bringing concerns or questions to group meetings. Major questions were referred for discussion with the project's steering committee.

We were unable to capture data for two planned elements in our protocol due to low reporting of these elements. Specifically, we were unable to extract information about users' needs and personal contexts (item numbered iv in our protocol) and about measures of feasibility, acceptability, and usability.

\section{Data quality assessment}

The quality of each article was appraised by two independent reviewers guided by a scoring system developed to score and appraise studies in a mixed method review [27]. We adapted and modified this tool by adding specific criteria for intervention development studies, a study type not previously represented in the original system. Because of the exploratory, descriptive nature of our study and because there were no established thresholds in this area, we did not set thresholds for quality. 


\section{Data validation}

Because of the heterogeneity of reporting of development processes, we contacted all authors to verify our extraction of key variables, including the merging of articles into projects; and to collect any data that we were unable to extract from publications. We also invited authors to provide additional articles that might further inform our understanding of their development process. We began by sending each corresponding author an email, following as needed with up to three reminder emails spaced one to two weeks apart. For nonresponding corresponding authors of randomized controlled trials, we also followed up with phone calls. When authors provided additional information or corrected extracted data, we inserted the authors' statements into our data matrix. When authors submitted new articles, we extracted new data from those articles into our data matrix. In such cases, once again, two independent analysts extracted data, reconciled their extractions through discussion until consensus was reached, and discussed points and questions at regular team meetings.

After updates were made based on authors' feedback, an independent analyst who had not been involved in data extraction screened all changes and classified them into one of four categories: (1) addition of previously missing data, (2) precision of data we had extracted more vaguely (e.g., we extracted "at least 3 iterative cycles" and the author informed us that they conducted 5 cycles), (3) correction of incorrect data, or (4) differences that did not materially affect the extracted data (e.g., we had extracted a development step as "not reported", which would be analyzed as lack of information that the step was done, and the authors confirmed that it was not done, changing our data entry to "not done").

If, after data extraction and validation, we did not have any indication that a development step had been conducted, we analyzed the step as not done. We applied this same approach to all data extracted. For example, if a step had been reported as being done but we had no data that users had been involved in it, we recorded that users had not been involved in the step, even if the combination was unusual; for example, if authors reported conducting a pilot test but did not report any participants being involving in the pilot test.

\section{Combining papers into projects}

For some projects, data was distributed across multiple papers. Prior to data analysis, we linked all articles describing different aspects of the same projects to develop and/or evaluate a given patient decision aid or other patient-centered tool. We conducted linkage by first grouping papers by clinical context, authors, and, when available, name of the tool. We then manually linked papers and verified our linkages when we contacted authors. Our unit of analysis is therefore each project of developing one patient decision aid or other patient-centered tool. Projects may have multiple papers.

\section{Synthesis of results}

To understand our data sets describing the development of patient decision aids (hereafter referred to as "patient decision aid projects") and the application of user-centered design to 
develop other patient-centered tools (hereafter referred to as "user-centered design projects") we first assessed the frequencies of their basic characteristics such as clinical context and timing of each tool's intended use.

We then conducted descriptive analyses, overall and by user-centered design element, with which patient decision aid projects and user-centered design projects reported conducting development steps, involving users in those steps, and the number of users involved and other aspects of development processes such as iteration. We elected not to conduct formal hypothesis testing between patient decision aid projects and user-centered design projects for three reasons. First, even with adjustment for multiple comparisons, the large number of variables would likely result in spurious findings. Second, the purpose of presenting both groups of results was to offer context from actual practices in user-centered design when situating patient decision aid projects within this framework, not to formally compare approaches. Third, and importantly, user-centered design projects designed and developed different kinds of tools than patient decision aids. Namely, such projects frequently had to do with physical assistive devices or tools designed for daily use, not tools intended to be used as a complement to a clinical consultation. Therefore, any differences we observed could simply reflect different types of tools.

We conducted these analyses on projects that explicitly reported at least one step of their development process. We performed descriptive analyses in R, version 3.2.3 [28] and SAS, version 9.4.

\section{Results}

Tabular details of all results are presented in Tables 3 and 4 below, and in Appendix 3 .

\section{Study selection}

In total, our searches identified 83,441 unique potentially eligible articles. Of these, we retained 1032 articles for full-text screening to which we added 53 articles identified through author suggestions and 109 articles from our hand search. After full text screening, we retained and extracted data from 623 articles. The search results and reasons for exclusion are presented in the PRISMA Flow Diagram, Figure 2. 
Figure 2. PRISMA Flow Diagram

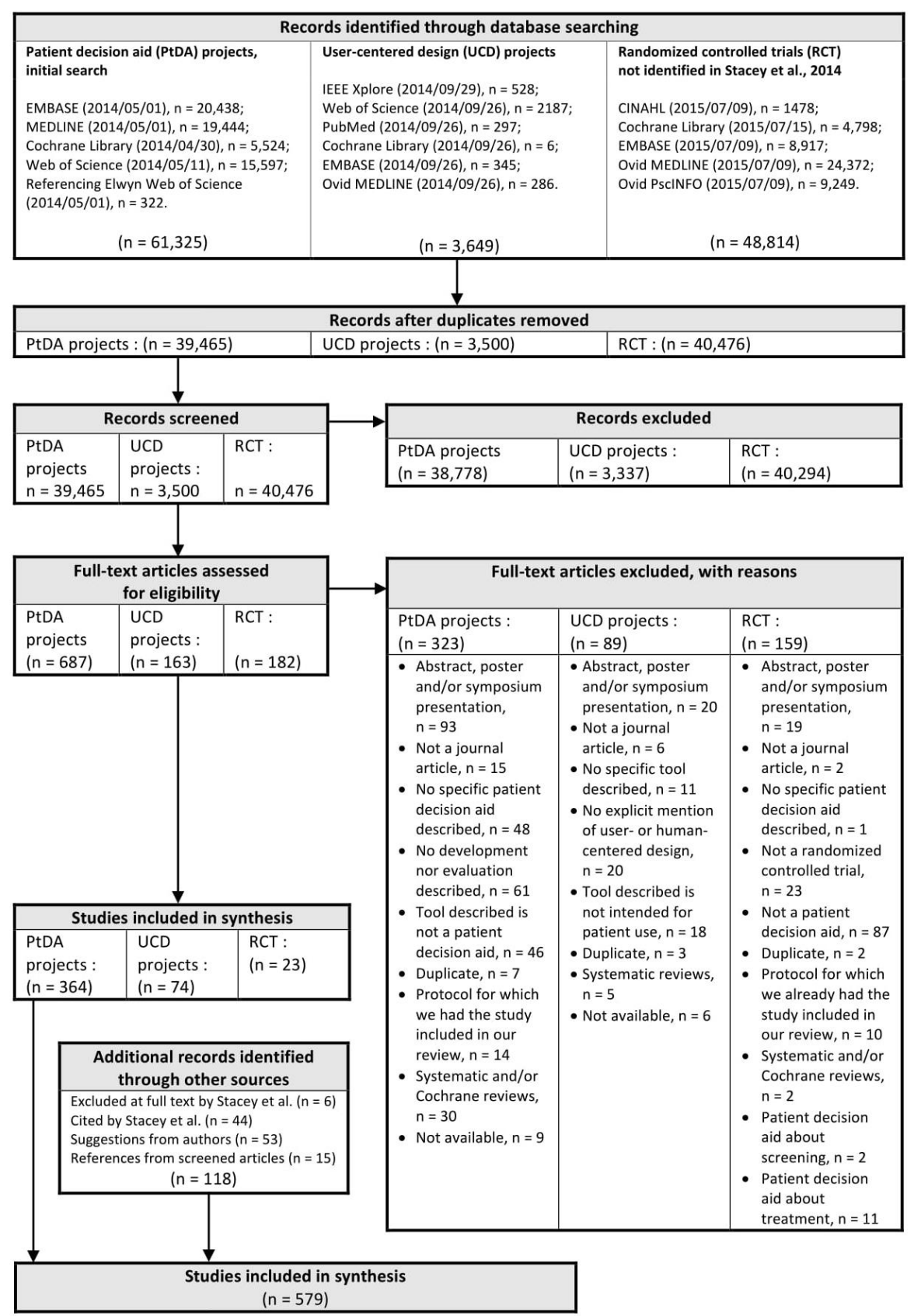

The 623 included articles described 390 distinct projects. Each project represented one unique patient decision aid or other patient-centered tool (tables 1 and 2). Three hundred and twentyfive $(83 \%)$ projects developed patient decision aids; 65 (17\%) projects developed patientcentered tools using user-centered design. Within the patient decision aid group of projects ( $n=325), 283$ of projects associated articles described at least one development step while 42 exclusively described the tool's evaluation. Of the 283 patient decision aid development projects, 2 descriptions explicitly stated the development process was user-centered design. We had predetermined in our protocol that we would group these with patient decision aid projects. 
Table 1. Included Patient Decision Aid Projects

\begin{tabular}{|c|c|c|}
\hline Articles in this project & $\begin{array}{l}\text { Patient decision aid name } \\
\text { (if name exists) }\end{array}$ & Clinical context \\
\hline Agre et al., 1994[44] & & Colorectal Cancer \\
\hline Akl et al., 2007[45] & & $\begin{array}{l}\text { Chronic Obstructive } \\
\text { Pulmonary Disorder }\end{array}$ \\
\hline AlFaleh et al., 2011[46] & & $\begin{array}{l}\text { Low Birth Weight Infants } \\
\text { (Patent Ductus Arteriosus) }\end{array}$ \\
\hline Allen et al., 2009[47] & & Prostate Cancer \\
\hline Allen et al., 2010[48] & & Prostate Cancer \\
\hline Ameling et al., 2012[49] & $\begin{array}{l}\text { "Preparing for Kidney } \\
\text { Treatment: You Have a } \\
\text { Choice" }\end{array}$ & $\begin{array}{l}\text { Advanced Chronic Kidney } \\
\text { Disease }\end{array}$ \\
\hline Anderson et al., 2011[50] & & Ovarian Cancer \\
\hline Aneja et al., 2012[51] & Skinsafe & Melanoma \\
\hline Aoki et al., 2007[52] & $\begin{array}{l}\text { u-SHARE (ubiquitously- } \\
\text { Support and Heal patients } \\
\text { with intracranial Aneurysms } \\
\text { with Risk communication and } \\
\text { Empowerment) }\end{array}$ & $\begin{array}{l}\text { Unruptured Intracranial } \\
\text { Aneurysms }\end{array}$ \\
\hline Arimori, 2006[53] & $\begin{array}{l}\text { Ottawa Personal Decision } \\
\text { Guide (translated into } \\
\text { Japanese) }\end{array}$ & Reproductive Health \\
\hline Arterburn et al., 2011[54] & $\begin{array}{l}\text { Weight Loss Surgery: Is It } \\
\text { right For You? }\end{array}$ & Obesity \\
\hline $\begin{array}{l}\text { Au et al., 2011[55]; Lam et } \\
\text { al., 2013[56] }\end{array}$ & & Breast Cancer \\
\hline Auvinen et al., 2004[57] & & Prostate Cancer \\
\hline $\begin{array}{l}\text { Baena Canada et al., } \\
\text { 2010[58] }\end{array}$ & Adjuvant! Online & Breast Cancer \\
\hline $\begin{array}{l}\text { Bailey Jr. et al., 2013a[59]; } \\
\text { Bailey Jr. et al., 2013b[60] }\end{array}$ & & Fragile $X$ Syndrome \\
\hline Barnieh et al., 2011[61] & & End-Stage Renal Disease \\
\hline $\begin{array}{l}\text { Barry et al., 1995[62]; Barry } \\
\text { et al., 1997[63]; Piercy et al., }\end{array}$ & $\begin{array}{l}\text { The Shared Decision Making } \\
\text { Program (SDP) }\end{array}$ & Benign Prostatic Hyperplasia \\
\hline
\end{tabular}




\begin{tabular}{|c|c|c|}
\hline $\begin{array}{l}\text { 1999[64]; Rovner et al., } \\
\text { 2004[65]; Holmes-Rovner et } \\
\text { al., 2006[66]; Wills et al., } \\
\text { 2006[67]; Pylar et al., } \\
\text { 2007[68] }\end{array}$ & & \\
\hline Bass et al., 2013[69] & & Colorectal Cancer \\
\hline $\begin{array}{l}\text { Bastian et al., 2002[70]; } \\
\text { McBride et al., 2002[71] }\end{array}$ & & $\begin{array}{l}\text { Reproductive Health; Breast } \\
\text { Cancer }\end{array}$ \\
\hline Beach et al., 1976[72] & & Reproductive Health \\
\hline Beamond et al., 2009[73] & & Interphalangeal Joint Arthritis \\
\hline Becker et al., 2009[74] & & Reproductive Health \\
\hline $\begin{array}{l}\text { Bekker et al., 1999[75]; } \\
\text { Bekker et al., 2004[76] }\end{array}$ & & $\begin{array}{l}\text { Reproductive Health; Down } \\
\text { Syndrome }\end{array}$ \\
\hline Berman et al., 2011[77] & & Abdominal Aortic Aneurysms \\
\hline Bernstein et al., 1998[78] & $\begin{array}{l}\text { Treatment Choices for } \\
\text { Ischaemic Heart Disease: A } \\
\text { Shared-Decision Making } \\
\text { Program Videotape }\end{array}$ & Cardiovascular Health \\
\hline $\begin{array}{l}\text { Berry et al., 2010[79]; Berry } \\
\text { et al., 2013[80] }\end{array}$ & $\begin{array}{l}\text { The Personal Patient-Profile } \\
\text { Prostate (P3P) }\end{array}$ & Prostate Cancer \\
\hline Bieber et al., 2004[81] & & Fibromyalgia \\
\hline $\begin{array}{l}\text { Björklund et al., 2012[82]; } \\
\text { Öhman et al., 2012[83] }\end{array}$ & & Reproductive Health \\
\hline $\begin{array}{l}\text { Breslin et al., 2008[84]; } \\
\text { Mullan et al., 2009[85] }\end{array}$ & Diabetes Medication Choice & Diabetes \\
\hline $\begin{array}{l}\text { Brink et al., 2000[86]; } \\
\text { Fagerlin et al., 2004[87]; } \\
\text { Taylor et al., 2010[88] }\end{array}$ & $\begin{array}{l}\text { Prostate Cancer: Your } \\
\text { Decision Notebook }\end{array}$ & Prostate Cancer \\
\hline $\begin{array}{l}\text { Brohan et al., 2014a[89]; } \\
\text { Brohan et al., 2014b[90] }\end{array}$ & $\begin{array}{l}\text { CORAL or COnceal or } \\
\text { ReveAL }\end{array}$ & Mental Illness \\
\hline $\begin{array}{l}\text { Brundage et al., 2000[91]; } \\
\text { Brundage et al., 2001[92] }\end{array}$ & & Lung Cancer \\
\hline Brunette et al., 2011[93] & & Smoking \\
\hline $\begin{array}{l}\text { Caldon et al., 2011[94]; } \\
\text { Jones, 2012[95]; Sivell et al., }\end{array}$ & BresDex & Breast Cancer \\
\hline
\end{tabular}




\begin{tabular}{|c|c|c|}
\hline $\begin{array}{l}\text { 2012a[96]; Sivell et al., } \\
\text { 2012b[97] }\end{array}$ & & \\
\hline Carrère et al., 2000[98] & & Breast Cancer \\
\hline Chewning et al., 1999[99] & $\begin{array}{l}\text { Aid For Contraceptive } \\
\text { Decision-making (ACD) } \\
\text { Program }\end{array}$ & Reproductive Health \\
\hline Chiew et al., 2008[100] & & Breast Cancer \\
\hline Chiou \& Chung, 2011[101] & & End-Stage Renal Disease \\
\hline Clancy et al., 1988[102] & & Vaccine-Preventable Disease \\
\hline Consoli et al., 1995[103] & ISIS & Cardiovascular Health \\
\hline Costanza et al., 2011[104] & & Prostate Cancer \\
\hline Cox et al., 2012[105] & & $\begin{array}{l}\text { Prolonged Mechanical } \\
\text { Ventilation }\end{array}$ \\
\hline Coylewright et al., 2012[106] & PCI Choice & Cardiovascular Health \\
\hline Cranney et al., 2002[107] & & Osteoporosis \\
\hline Culver et al., 2011[108] & & $\begin{array}{l}\text { Breast Cancer; Ovarian } \\
\text { Cancer }\end{array}$ \\
\hline Cupertino et al., 2010[109] & You Can Choose & Smoking \\
\hline $\begin{array}{l}\text { Dales et al., 1999[110]; } \\
\text { Wilson et al., 2005[111] }\end{array}$ & & $\begin{array}{l}\text { Advanced Care Planning; } \\
\text { Chronic Obstructive } \\
\text { Pulmonary Disorder }\end{array}$ \\
\hline D'Alimonte et al., 2012[112] & & Breast Cancer \\
\hline Davis et al., 1998[113] & & Vaccine-Preventable Disease \\
\hline Deschamps et al., 2004[114] & $\begin{array}{l}\text { Making Choices: Hormones } \\
\text { After Menopause }\end{array}$ & Reproductive Health \\
\hline Dillard et al., 2010[115] & & Colorectal Cancer \\
\hline Dobs et al., 1994[116] & & Cardiovascular Health \\
\hline Dodin et al., 2001[117] & & Reproductive Health \\
\hline Dolan \& Frisina, 2002[118] & & Colorectal Cancer \\
\hline Dolan et al., 2013[119] & & Knee Osteoarthritis \\
\hline Dowding et al., 2004[120]; & & Benign Prostatic Hyperplasia; \\
\hline
\end{tabular}




\begin{tabular}{|l|l|l|}
\hline Thomson et al., 2006[121] & & Cardiovascular Health \\
\hline $\begin{array}{l}\text { Drake et al., 1999[122]; } \\
\text { Hunter et al., 2005[123] }\end{array}$ & & Reproductive Health \\
\hline Drake et al., 2010[124] & Road Map & Prostate Cancer \\
\hline Du et al., 2008[125] & $\begin{array}{l}\text { Cancer Clinical Trials: An } \\
\text { Introduction for Patients and } \\
\text { their Families }\end{array}$ & Lung Cancer \\
\hline Dunn et al., 1998[126] & & Vaccine-Preventable Disease \\
\hline $\begin{array}{l}\text { Durand, 2009[127]; Durand et } \\
\text { al., 2010[128]; Durand et al., } \\
\text { 2012[129] }\end{array}$ & amnioDex & Reproductive Health \\
\hline $\begin{array}{l}\text { Eden et al., 2009[130]; Eden } \\
\text { et al., 2014[131] }\end{array}$ & & Reproductive Health \\
\hline Elit et al., 1996[132] & The Decision Board (DB) & Ovarian Cancer \\
\hline $\begin{array}{l}\text { El-Jawahri et al., 2010[133]; } \\
\text { Volandes et al., 2012[134]; } \\
\text { Volandes et al., 2013[135] }\end{array}$ & & Advance Care Planning; \\
\hline $\begin{array}{l}\text { Emmett et al., 2007[136]; } \\
\text { Montgomery et al., } \\
\text { 2007[137]; Frost et al., } \\
\text { 2009[138]; Hollinghurst et al., } \\
\text { 2010[139] }\end{array}$ & & Cancer \\
\hline $\begin{array}{l}\text { Evans et al., 2007[140]; } \\
\text { Evans et al., 2010[141]; } \\
\text { Joseph-Williams et al., } \\
\text { 2010[142] }\end{array}$ & Prosdex & Reproductive Health \\
\hline $\begin{array}{l}\text { Fagerlin et al., 2010[143]; } \\
\text { Fagerlin et al., 2011[144]; } \\
\text { Banegas et al., 2013[145]; } \\
\text { Korfage et al., 2013[146] }\end{array}$ & Guide to Decide & \\
\hline Farnworth et al., 2008[147] & & Rreast Cancer \\
\hline $\begin{array}{l}\text { Feldman-Stewart et al., } \\
\text { 2000[148]; Feldman-Stewart } \\
\text { et al., 2001a[149]; Feldman- } \\
\text { Stewart et al., 2001b[150]; } \\
\text { Feldman-Stewart et al., } \\
\text { 2003[151]; Feldman-Stewart } \\
\text { et al., 2004[152]; Feldman- }\end{array}$ & & Prostate Cancer \\
\hline
\end{tabular}




\begin{tabular}{|c|c|c|}
\hline $\begin{array}{l}\text { Stewart et al., 2006a[153]; } \\
\text { Feldman-Stewart et al., } \\
\text { 2006b[154]; Feldman-Stewart } \\
\text { et al., 2012[155] }\end{array}$ & & \\
\hline $\begin{array}{l}\text { Fetters et al., 2004[152]; } \\
\text { Ruffin et al., 2007[156] }\end{array}$ & Colorectal Web & Colorectal Cancer \\
\hline Fiks et al., 2013[157] & & Vaccine-Preventable Disease \\
\hline Fiset et al., 2000[158] & $\begin{array}{l}\text { "Making Choices: Treatment } \\
\text { of Stage IV Non-Small Cell } \\
\text { Lung Cancer" }\end{array}$ & Lung Cancer \\
\hline $\begin{array}{l}\text { Fleisher et al., 2008[159]; } \\
\text { Meropol et al., 2013[160] }\end{array}$ & CONNECT ${ }^{a}$ & Cancer \\
\hline $\begin{array}{l}\text { Flood et al., 1996[161]; Partin } \\
\text { et al., 2004[162]; Partin et al., } \\
\text { 2006[163] }\end{array}$ & $\begin{array}{l}\text { The PSA Decision: What } \\
\text { YOU Need to Know }\end{array}$ & Prostate Cancer \\
\hline $\begin{array}{l}\text { Flood et al., 1996[161]; Partin } \\
\text { et al., 2004[162]; Partin et al., } \\
\text { 2006[163] }\end{array}$ & $\begin{array}{l}\text { The PSA Decision: Is it Right } \\
\text { for ME? }\end{array}$ & Prostate Cancer \\
\hline $\begin{array}{l}\text { Fortin et al., 2001[164]; Bond } \\
\text { et al., 2002[165]; Col et al., } \\
\text { 2007[166] }\end{array}$ & & Reproductive Health \\
\hline $\begin{array}{l}\text { Fraenkel et al., 2007[167]; de } \\
\text { Achaval et al., 2012[168] }\end{array}$ & & Knee Osteoarthritis \\
\hline $\begin{array}{l}\text { Fraenkel et al., 2011[169]; } \\
\text { Fraenkel et al., 2012[170] }\end{array}$ & & Cardiovascular Health \\
\hline $\begin{array}{l}\text { Fraenkel et al., 2012[171]; } \\
\text { Fraenkel et al., 2015[172] }\end{array}$ & & Rheumatoid Arthritis \\
\hline Frank et al., 2010[173] & & $\begin{array}{l}\text { Hospitalized Patients }(50 \% \\
\text { risk of death) }\end{array}$ \\
\hline French et al., 2014[174] & My Contraception Tool (MCT) & Reproductive Health \\
\hline $\begin{array}{l}\text { Frosch et al., 2001[175]; } \\
\text { Frosch et al., 2003[176] }\end{array}$ & $\begin{array}{l}\text { The PSA Decision: What You } \\
\text { Need To Know }\end{array}$ & Prostate Cancer \\
\hline Frosch et al., 2008[177] & & $\begin{array}{l}\text { Prostate Cancer; Colorectal } \\
\text { Cancer }\end{array}$ \\
\hline $\begin{array}{l}\text { Frosch et al., 2008[178]; } \\
\text { Bhatnagar et al., 2009[179] }\end{array}$ & & Prostate Cancer \\
\hline
\end{tabular}




\begin{tabular}{|c|c|c|}
\hline Furber et al., 2014[180] & & Cancer \\
\hline $\begin{array}{l}\text { Gallo et al., 2010[181]; Wilkie } \\
\text { et al., 2013[182]; Gallo et al., } \\
2014[183]\end{array}$ & CHOICES & $\begin{array}{l}\text { Reproductive Health; Sickle } \\
\text { Cell Disease and Sickle Cell } \\
\text { Trait }\end{array}$ \\
\hline Garvelink et al., 2013[184] & & $\begin{array}{l}\text { Reproductive Health; Breast } \\
\text { Cancer }\end{array}$ \\
\hline $\begin{array}{l}\text { Gattellari \& Ward, 2003[185]; } \\
\text { Gattellari \& Ward, 2005[186] }\end{array}$ & $\begin{array}{l}\text { LEAFLET ("Testing for } \\
\text { prostate cancer"); } \\
\text { VIDEO ("The choice is yours: } \\
\text { testing for prostate cancer"); } \\
\text { BOOKLET ("Should I have a } \\
\text { PSA test for prostate cancer: } \\
\text { information for men who want } \\
\text { to know more about } \\
\text { screening tests for prostate } \\
\text { cancer") }\end{array}$ & Prostate Cancer \\
\hline Gilbert et al., 2008[187] & Positive Choice & $\begin{array}{l}\text { Reproductive Health; Human } \\
\text { Immunodeficiency Virus }\end{array}$ \\
\hline Graham et al., 2000[188] & & Reproductive Health \\
\hline $\begin{array}{l}\text { Grant et al., 2001[189]; } \\
\text { Laupacis et al., 2006[190] }\end{array}$ & & Cardiovascular Health \\
\hline $\begin{array}{l}\text { Green \& Fost, 1997[191]; } \\
\text { Lerman et al., 1997[192]; } \\
\text { Green et al., 2001[193]; } \\
\text { Schwartz et al., 2001[194]; } \\
\text { Green et al., 2004[195]; } \\
\text { Green et al., 2005[196]; }\end{array}$ & $\begin{array}{l}\text { Breast Cancer Risk and } \\
\text { Genetic Testing }\end{array}$ & Breast Cancer \\
\hline $\begin{array}{l}\text { Green et al., 2009[197]; } \\
\text { Hossler et al., 2011[198]; } \\
\text { Markham et al., 2015[199] }\end{array}$ & $\begin{array}{l}\text { Making Your Wishes Known: } \\
\text { Planning Your Medical Future }\end{array}$ & $\begin{array}{l}\text { Advance Care Planning; } \\
\text { Amyotrophic Lateral Sclerosis }\end{array}$ \\
\hline Griffith et al., 2005[200] & & Reproductive Health \\
\hline Guillén et al., 2012[201] & & Reproductive Health \\
\hline $\begin{array}{l}\text { Gustafson et al., 1994[202]; } \\
\text { Gustafson et al., 2001[203]; } \\
\text { Wise et al., 2008[204] }\end{array}$ & $\begin{array}{l}\text { Comprehensive Health } \\
\text { Enhancement Support } \\
\text { System (CHESS) }\end{array}$ & Breast Cancer \\
\hline $\begin{array}{l}\text { Gustafson et al., 1994[205]; } \\
\text { Gustafson et al., 1999[206] }\end{array}$ & $\begin{array}{l}\text { Comprehensive Health } \\
\text { Enhancement Support } \\
\text { System (CHESS) }\end{array}$ & $\begin{array}{l}\text { Human Immunodeficiency } \\
\text { Virus Infection and Acquired } \\
\text { Immune Deficiency } \\
\text { Syndrome }\end{array}$ \\
\hline
\end{tabular}




\begin{tabular}{|c|c|c|}
\hline $\begin{array}{l}\text { Hacking et al., 2013[207]; } \\
\text { Hacking et al., 2014[208] }\end{array}$ & Decision Navigation & Prostate Cancer \\
\hline $\begin{array}{l}\text { Hamann et al., 2006[209]; } \\
\text { Hamann et al., 2007[210] }\end{array}$ & & Schizophrenia \\
\hline Hartling et al., 2013[211] & & Croup \\
\hline Harwood et al., 2011[212] & & Breast Cancer \\
\hline $\begin{array}{l}\text { Hawkins Virani et al., } \\
\text { 2013[213] }\end{array}$ & & Huntington Disease \\
\hline Heinrich et al., 2012[214] & \begin{tabular}{|l|} 
Diabetes Interactive \\
Education Programme (DIEP)
\end{tabular} & Diabetes \\
\hline Heller et al., 2008[215] & & Breast Cancer \\
\hline Henderson et al., 2013[216] & iDecide/Decido & Diabetes \\
\hline Hewison et al., 2001[217] & & $\begin{array}{l}\text { Reproductive Health; Down } \\
\text { Syndrome }\end{array}$ \\
\hline $\begin{array}{l}\text { Hightow-Weidman et al., } \\
\text { 2011[218]; Muessig et al., } \\
\text { 2013[219]; Muessig et al., } \\
\text { 2014[220]; Hightow-Weidman } \\
\text { et al., 2015[221] }\end{array}$ & HealthMpowerment.org & $\begin{array}{l}\text { Human Immunodeficiency } \\
\text { Virus; Sexually Transmitted } \\
\text { Infections }\end{array}$ \\
\hline $\begin{array}{l}\text { Hill-Briggs et al., 2008[222]; } \\
\text { Schumann et al., 2011[223]; } \\
\text { Majid et al., 2012[224] }\end{array}$ & DECIDE program & Diabetes \\
\hline Hochlehnert et al., 2006[225] & & Chronic Pain (Fibromyalgia) \\
\hline Hoffner et al., 2012[226] & $\begin{array}{l}\text { Entering a Clinical Trial: Is it } \\
\text { Right for You? (The Clinical } \\
\text { Trials Video) }\end{array}$ & Cancer \\
\hline Holbrook et al., 2007[227] & & $\begin{array}{l}\text { Overall Health; } \\
\text { Cardiovascular Health }\end{array}$ \\
\hline Hollen et al., 2013a[228] & $\begin{array}{l}\text { DecisionKEYS for Balancing } \\
\text { Choices }\end{array}$ & $\begin{array}{l}\text { Prostate Cancer; Breast } \\
\text { Cancer; Lung Cancer }\end{array}$ \\
\hline Hollen et al., 2013b[229] & $\begin{array}{l}\text { DecisionKEYS for Balancing } \\
\text { Choices: Adolescent } \\
\text { Substance Use }\end{array}$ & Substance Use \\
\hline $\begin{array}{l}\text { Holmes-Rovner et al., } \\
\text { 2005[230] }\end{array}$ & & Prostate Cancer \\
\hline
\end{tabular}




\begin{tabular}{|l|l|l|}
\hline Hong et al., 2013[231] & PtDA-WD & Cardiovascular Health \\
\hline Hooker et al., 2011[232] & & Breast Cancer \\
\hline Hope \& Rombauts, 2010[233] & & Reproductive Health \\
\hline Hutchison et al., 2002[234] & $\begin{array}{l}\text { Phase I Clinical Trials: What } \\
\text { Are They All About? }\end{array}$ & Cancer \\
\hline Huyghe et al., 2009[235] & $\begin{array}{l}\text { Banking on Fatherhood } \\
\text { (BOF) }\end{array}$ & Reproductive Health \\
\hline Irwin et al., 1999[236] & & Breast Cancer \\
\hline Isebaert et al., 2008[237] & & Prostate Cancer \\
\hline Izquierdo et al., 2011[238] & & Breast Cancer \\
\hline $\begin{array}{l}\text { Jackson et al., 2010[239]; } \\
\text { Shourie et al., 2013[240]; } \\
\text { Tubeuf et al., 2014[241] }\end{array}$ & MMR decision aid & Vaccine Preventable Disease \\
\hline Jefford et al., 2005[242] & & Colorectal Cancer \\
\hline Jenkins et al., 2007[243] & & Chronic Kidney Disease \\
\hline Jenkinson et al., 1998[244] & The Prostate Centre & Prostate Cancer \\
\hline Jensen et al., 1995[245] & & Breast Cancer \\
\hline $\begin{array}{l}\text { Jibaja-Weiss et al., } \\
\text { 2006a[246]; Jibaja-Weiss et } \\
\text { al., 2006b[247]; Jibaja-Weiss } \\
\text { et al., 2011[248] }\end{array}$ & $\begin{array}{l}\text { A Patchwork of Life: A } \\
\text { Wor Women Making Breast } \\
\text { Cancer Treatment Decisions }\end{array}$ & Breast Cancer \\
\hline Johnson et al., 2006[249] & Rearoductive Health \\
\hline $\begin{array}{l}\text { Johnson et al., 2010[250]; } \\
\text { Langston et al., 2010[251] }\end{array}$ & $\begin{array}{l}\text { Decision-Making Tool for } \\
\text { Family Planning Clients and } \\
\text { Providers }\end{array}$ & Endotontics \\
\hline $\begin{array}{l}\text { Juan et al., 2008[252] } \\
\text { Kuaufman et al., 2003[257] }\end{array}$ & & $\begin{array}{l}\text { Breast Cancer; Ovarian } \\
\text { Cancer }\end{array}$ \\
\hline $\begin{array}{l}\text { Kasper et al., 2008[255]; } \\
\text { Köpke et al., 2014[256] }\end{array}$ & \begin{tabular}{l} 
Cancer \\
\hline Juctasceast Cancer \\
decision aid (DCISDA)
\end{tabular} & Multiple Sclerosis \\
\hline
\end{tabular}




\begin{tabular}{|l|l|l|}
\hline $\begin{array}{l}\text { Kellar et al., 2008[258]; Mann } \\
\text { et al., 2010[259]; Marteau et } \\
\text { al., 2010[260]; Kellar et al., } \\
\text { 2011[261] }\end{array}$ & Diabetes \\
\hline $\begin{array}{l}\text { Kennedy et al., 2002[262]; } \\
\text { Kennedy et al., 2003[263] }\end{array}$ & & Reproductive Health \\
\hline Kiatpongsan et al., 2013[264] & $\begin{array}{l}\text { Managing Menopause: } \\
\text { Choosing Treatments for } \\
\text { Menopause Symptoms }\end{array}$ & Reproductive Health \\
\hline Knapp et al., 2010[265] & & Cardiovascular Health \\
\hline Köpke et al., 2012[266] & EBSIMS-program & Multiple Sclerosis \\
\hline Krist et al., 2007[267] & & Prostate Cancer \\
\hline Krones et al., 2010[268] & ARRIBA-Herz & Cardiovascular Health \\
\hline Kupke et al., 2013[269] & & $\begin{array}{l}\text { Class-II Defect (defect in a } \\
\text { posterior tooth) }\end{array}$ \\
\hline Kuppermann et al., 2009[270] & $\begin{array}{l}\text { Prenatal Testing Decision- } \\
\text { Assisting Tool (PT Tool) }\end{array}$ & Reproductive Health \\
\hline $\begin{array}{l}\text { Kuppermann et al., } \\
\text { 2014[271]; Norton et al., } \\
\text { 2014[272] }\end{array}$ & $\begin{array}{l}\text { Prenatal Testing: Exploring } \\
\text { Your Options }\end{array}$ & Reproductive Health \\
\hline Labrecque et al., 2010[273] & & Reast \\
\hline $\begin{array}{l}\text { Lalonde et al., 2004[274]; } \\
\text { Lalonde et al., 2006[275] }\end{array}$ & $\begin{array}{l}\text { Making Choices: Life } \\
\text { Changes to Lower Your Risk } \\
\text { of Heart Disease and Stroke }\end{array}$ & Cardiovascular Health \\
\hline LaVista et al., 2009[276] & $\begin{array}{l}\text { Hydroxyurea : Is it Your Hope } \\
\text { for Better Days? }\end{array}$ & Sickle Cell Disease \\
\hline Lawrence et al., 2000[277] & & Breast Cancer \\
\hline Lee et al., 2010[278] & Rreast Cancer \\
\hline Légaré et al., 2003[279] & Reproductive Health \\
\hline $\begin{array}{l}\text { Légaré et al., 2007[280]; } \\
\text { Menard et al., 2010[282] }\end{array}$ & Leight et al., 2008[284] & Reproductive Health \\
\hline Légaré et al., 2010[283] & RespisION + & \\
\hline Leancer \\
\hline
\end{tabular}




\begin{tabular}{|c|c|c|}
\hline Leighl et al., 2011[285] & & Colorectal Cancer \\
\hline Lenert \& Cher, 1999[286] & & Benign Prostatic Hyperplasia \\
\hline Lerman et al., 1995[287] & & Breast Cancer \\
\hline Leung et al., 2004[288] & & Reproductive Health \\
\hline Lewis et al., 2008[289] & $\begin{array}{l}\text { Colon Cancer Screening: } \\
\text { Deciding What's Right for } \\
\text { You }\end{array}$ & Colorectal Cancer \\
\hline Lewis et al., 2010[290] & & Colorectal Cancer \\
\hline $\begin{array}{l}\text { Lewis et al., 2010[291]; Miller } \\
\text { et al., 2011[292]; Pignone et } \\
\text { al., 2011[293] }\end{array}$ & $\begin{array}{l}\text { CHOICE (Communicating } \\
\text { Health Options through } \\
\text { Interactive Computer } \\
\text { Education; version 6.0W) }\end{array}$ & Colorectal Cancer \\
\hline $\begin{array}{l}\text { Li et al., 2013[294]; Li et al., } \\
\text { 2014[295] }\end{array}$ & $\begin{array}{l}\text { ANimated; Self-serve WEb- } \\
\text { based Research (ANSWER) }\end{array}$ & Rheumatoid Arthritis \\
\hline $\begin{array}{l}\text { Liao et al., 1996[296]; } \\
\text { Morgan et al., 2000[297] }\end{array}$ & $\begin{array}{l}\text { Ischemic Heart Disease } \\
\text { Shared Decision-Making } \\
\text { Program (IHD SDP) }\end{array}$ & Cardiovascular Health \\
\hline Loh et al., 2007[298] & & Depression \\
\hline Lurie et al., 2011[299] & & Herniated Disc \\
\hline Makoul et al., 2009[300] & $\begin{array}{l}\text { Patient Education } \\
\text { Program/Programa Educativo } \\
\text { para Patientes (PEP) }\end{array}$ & Colorectal Cancer \\
\hline Mancini et al., 2006[301] & & $\begin{array}{l}\text { Breast Cancer; Ovarian } \\
\text { Cancer }\end{array}$ \\
\hline Manne et al., 2009[302] & $\begin{array}{l}\text { "The Good News: Colorectal } \\
\text { Cancer is Preventable!" }\end{array}$ & Colorectal Cancer \\
\hline Manne et al., 2010[303] & & Colorectal Cancer \\
\hline $\begin{array}{l}\text { Man-Son-Hing et al., } \\
\text { 1999[304]; Man-Son-Hing et } \\
\text { al., 2000[305]; McAlister et } \\
\text { al., 2005[306] }\end{array}$ & & Cardiovascular Health \\
\hline Masaracchia et al., 1999[307] & & Intestinal Problems \\
\hline Maslin et al., 1998[308] & & Breast Cancer \\
\hline Mathers et al., 2012[309]; Ng & PANDAs & Diabetes \\
\hline
\end{tabular}




\begin{tabular}{|c|c|c|}
\hline et al., 2014[310] & & \\
\hline Mathieu et al., 2007[311] & & Breast Cancer \\
\hline Mathieu et al., 2010[312] & & Breast Cancer \\
\hline Matlock et al., 2011[313] & $\begin{array}{l}\text { Looking Ahead: choices for } \\
\text { medical care when you're } \\
\text { seriously ill }\end{array}$ & Advance Care Planning \\
\hline $\begin{array}{l}\text { Mayberry, H. \& Mayberry, } \\
\text { J.F., 2007[314] }\end{array}$ & & Gastroscopy \\
\hline Mayer et al., 2010[315] & HSCT-CHESS & $\begin{array}{l}\text { Hematopoietic Stem Cell } \\
\text { Transplant }\end{array}$ \\
\hline $\begin{array}{l}\text { McCaffery \& Irwig, 2005[316]; } \\
\text { McCaffery et al., 2006[317]; } \\
\text { McCaffery et al., 2008[318]; } \\
\text { McCaffery et al., 2010[319] }\end{array}$ & & $\begin{array}{l}\text { Reproductive Health; Cervical } \\
\text { Cancer }\end{array}$ \\
\hline McKay et al., 2005[320] & & Breast Cancer \\
\hline Metcalfe et al., 2007[321] & & Breast Cancer \\
\hline Michie et al., 1997[322] & & $\begin{array}{l}\text { Reproductive Health; Down } \\
\text { Syndrome }\end{array}$ \\
\hline Miller et al., 2005[323] & & $\begin{array}{l}\text { Breast Cancer; Ovarian } \\
\text { Cancer }\end{array}$ \\
\hline Milne et al., 2009[324] & & Reproductive Health \\
\hline $\begin{array}{l}\text { Mitchell et al., 2001[325]; } \\
\text { Hanson et al., 2011[326]; } \\
\text { Snyder et al., 2013[327] }\end{array}$ & & Advanced Dementia \\
\hline $\begin{array}{l}\text { Molenaar et al., 2001a[328]; } \\
\text { Molenaar et al., 2001b[329]; } \\
\text { Molenaar et al., 2004[330]; } \\
\text { Molenaar et al., 2007[331]; }\end{array}$ & & Breast Cancer \\
\hline $\begin{array}{l}\text { Montgomery et al., } \\
\text { 2003[332]; Emmett et al., } \\
2005[333 \text { ] }\end{array}$ & & Cardiovascular Health \\
\hline $\begin{array}{l}\text { Montori et al., 2007[334]; } \\
\text { Weymiller et al., 2007[335]; } \\
\text { Jones et al., 2009[336]; } \\
\text { Nannenga et al., 2009[337]; } \\
\text { Mann et al., 2010[338] }\end{array}$ & Statin Choice & $\begin{array}{l}\text { Diabetes; Cardiovascular } \\
\text { Health }\end{array}$ \\
\hline
\end{tabular}




\begin{tabular}{|c|c|c|}
\hline Müller et al., 2012[339] & Change of life & Reproductive Health \\
\hline Murray et al., 2001a[340] & & Benign Prostatic Hypertrophy \\
\hline Murray et al., 2001b[341] & & Reproductive Health \\
\hline $\begin{array}{l}\text { Myers et al., 2005[342]; } \\
\text { Myers et al., 2011[343] }\end{array}$ & & Prostate Cancer \\
\hline $\begin{array}{l}\text { Nagle et al., 2006[344]; Nagle } \\
\text { et al., 2008[345] }\end{array}$ & & Reproductive Health \\
\hline $\begin{array}{l}\text { Nassar et al., 2007a[346]; } \\
\text { Nassar et al., 2007b[347] }\end{array}$ & $\begin{array}{l}\text { Making choices: options for a } \\
\text { pregnant woman with a } \\
\text { breech baby }\end{array}$ & Reproductive Health \\
\hline Nozaki et al., 2007[348] & $\begin{array}{l}\text { Diagnosis and Treatment for } \\
\text { Unruptured Cerebral } \\
\text { Aneurysm (Ver. } 1 \text { produced } \\
\text { in 2004) }\end{array}$ & $\begin{array}{l}\text { Unruptured Cerebral } \\
\text { Aneurysms }\end{array}$ \\
\hline $\begin{array}{l}\text { O'Connor et al., 1998a[349]; } \\
\text { O'Connor et al., 1998b[350]; } \\
\text { Rostom et al., 2002[351] }\end{array}$ & Ottawa HRT decision aid & Reproductive Health \\
\hline Oakley \& Walley, 2006[352] & & $\begin{array}{l}\text { Reproductive Health; } \\
\text { Osteoporosis }\end{array}$ \\
\hline O'Cathain et al., 2002[353] & & Reproductive Health \\
\hline O'Connor et al., 1999[354] & & Reproductive Health \\
\hline Ogle et al., 2003[355] & Completing a Life & Advance Care Planning \\
\hline Onel et al., 1998[356] & & Prostate Cancer \\
\hline Ossebaard et al., 2010[357] & & $\begin{array}{l}\text { Attention Deficit Hyperactivity } \\
\text { Disorder }\end{array}$ \\
\hline Owens \& Robbins, 1996[358] & CHESS & Breast Cancer \\
\hline Ozanne et al., 2007[359] & & Breast Cancer \\
\hline $\begin{array}{l}\text { Peate et al., 2011a[360]; } \\
\text { Peate et al., 2011b[361]; } \\
\text { Peate et al., 2012[362] }\end{array}$ & & $\begin{array}{l}\text { Reproductive Health; Breast } \\
\text { Cancer }\end{array}$ \\
\hline $\begin{array}{l}\text { Peele et al., 2005[363]; } \\
\text { Siminoff et al., 2006[364]; } \\
\text { Vickers et al., 2009[365] }\end{array}$ & Adjuvant! & Breast Cancer \\
\hline Pell et al., 2002[366] & & Ovarian Cancer \\
\hline
\end{tabular}




\begin{tabular}{|c|c|c|}
\hline $\begin{array}{l}\text { Pencille et al., 2009[367]; } \\
\text { Montori et al., 2011[368] }\end{array}$ & $\begin{array}{l}\text { The Osteoporosis Choice } \\
\text { decision aid }\end{array}$ & Osteoporosis \\
\hline $\begin{array}{l}\text { Perestelo-Perez et al., } \\
\text { 2010[369] }\end{array}$ & & Benign Prostatic Hyperplasia \\
\hline $\begin{array}{l}\text { Perestelo-Perez et al., } \\
\text { 2010[369] }\end{array}$ & & Depression \\
\hline $\begin{array}{l}\text { Perestelo-Perez et al., } \\
2010[369]\end{array}$ & & Hip or Knee Osteoarthritis \\
\hline $\begin{array}{l}\text { Permuth-Wey et al., } \\
2010[370]\end{array}$ & $\begin{array}{l}\text { Genetics and Breast Cancer } \\
\text { Risks in Black Women: A } \\
\text { Woman's Guide for Genetic } \\
\text { Counseling }\end{array}$ & $\begin{array}{l}\text { Breast Cancer; Ovarian } \\
\text { Cancer }\end{array}$ \\
\hline Peshkin et al., 2010[371] & & $\begin{array}{l}\text { Breast Cancer; Ovarian } \\
\text { Cancer }\end{array}$ \\
\hline Peterson et al., 2006[372] & & Li-Fraumeni Syndrome \\
\hline $\begin{array}{l}\text { Pierce et al., 2010[373]; Hess } \\
\text { et al., 2012[374] }\end{array}$ & & Cardiovascular Health \\
\hline $\begin{array}{l}\text { Pignone et al., 2000[375]; } \\
\text { Kim et al., 2005[376]; Griffith } \\
\text { et al., 2008a[377]; Griffith et } \\
\text { al., 2008b[378] }\end{array}$ & CHOICE & Colorectal Cancer \\
\hline $\begin{array}{l}\text { Pignone et al., 2004[379]; } \\
\text { Sheridan et al., 2006[380]; } \\
\text { Sheridan et al., 2009[381]; } \\
\text { Sheridan et al., 2010[382]; } \\
\text { Sheridan et al., 2011[383] }\end{array}$ & Heart to Heart & Cardiovascular Health \\
\hline $\begin{array}{l}\text { Protheroe et al., 2007a[384]; } \\
\text { Protheroe et al., 2007b[385] }\end{array}$ & The Clinical Guidance Tree & $\begin{array}{l}\text { Reproductive Health; } \\
\text { Menorrhagia }\end{array}$ \\
\hline Prunty et al., 2008[386] & & $\begin{array}{l}\text { Reproductive Health; Multiple } \\
\text { Sclerosis }\end{array}$ \\
\hline Raats et al., 2008[387] & & $\begin{array}{l}\text { Prostate Cancer; } \\
\text { Reproductive Health; } \\
\text { Depression; Breast Cancer; } \\
\text { Cardiovascular Health; Down } \\
\text { Syndrome }\end{array}$ \\
\hline Rapport et al., 2006[388] & $\begin{array}{l}\text { 1-GREEN; 2-PREDICT; and } \\
\text { 3-Deciding About } \\
\text { Mammography for Women }\end{array}$ & Breast Cancer \\
\hline
\end{tabular}




\begin{tabular}{|l|l|l|}
\hline & Age 40-49 & \\
\hline $\begin{array}{l}\text { Raynes-Greenow et al., } \\
\text { 2009[389]; Raynes-Greenow } \\
\text { et al., 2010[390] }\end{array}$ & & Reproductive Health \\
\hline Redfern et al., 2006[391] & & Cardiovascular Health \\
\hline Renzi et al., 2006[392] & & Psoriasis \\
\hline $\begin{array}{l}\text { Reuland et al., 2012[393]; Ko } \\
\text { et al., 2014[394] }\end{array}$ & & Colorectal Cancer \\
\hline Rhee et al., 2008[395] & & Asthma \\
\hline $\begin{array}{l}\text { Ronda et al., 2014[396]; } \\
\text { Ickenroth et al., 2015[397] }\end{array}$ & & Diabetes; Cardiovascular \\
\hline Ross et al., 2010[398] & $\begin{array}{l}\text { The PSA Test for Prostate } \\
\text { Cancer: Is it Right for Me? }\end{array}$ & Prostate Cancer \\
\hline $\begin{array}{l}\text { Rothert et al., 1997[399]; } \\
\text { Holmes-Rovner et al., } \\
\text { 1999[400] }\end{array}$ & & Reproductive Health \\
\hline Rubel et al., 2010[401] & & \\
\hline Ruland, 1999[402] & & Prostate Cancer \\
\hline $\begin{array}{l}\text { Ruthman \& Ferrans, } \\
\text { 2004[403] }\end{array}$ & $\begin{array}{l}\text { Video - The PSA Decision: } \\
\text { What You Need to Know }\end{array}$ & Prostate Cancer \\
\hline Saver et al., 2007[404] & CHESS-MAB & Reproductive Health \\
\hline $\begin{array}{l}\text { Sawka et al., 1998[405]; Goel } \\
\text { et al., 2001[406] }\end{array}$ & & Breast Cancer \\
\hline $\begin{array}{l}\text { Sawka et al., 2011a[407]; } \\
\text { Sawka et al., 2011b[408]; } \\
\text { Sawka et al., 2012[409] }\end{array}$ & & Papillary Thyroid Cancer \\
\hline $\begin{array}{l}\text { Schackmann et al., 2013[410] } \\
\text { Rchoproductive Health }\end{array}$ \\
\hline $\begin{array}{l}\text { Schapira \& VanRuiswyk, } \\
\text { 2000[411] }\end{array}$ & & Cancer \\
\hline Schapira et al., 1997[412] & & Prostate Cancer \\
\hline Schapira et al., 2007[413] & & Prostate Cancer \\
\hline Schonberg et al., 2014[414] & & \\
\hline
\end{tabular}




\begin{tabular}{|c|c|c|}
\hline Schoorel et al., 2014[415] & & Reproductive Health \\
\hline $\begin{array}{l}\text { Schroy et al., 2011[416]; } \\
\text { Schroy et al., 2012[417]; } \\
\text { Schroy et al., 2014[418] }\end{array}$ & & Colorectal Cancer \\
\hline Schwalm et al., 2012[419] & & Cardiovascular Health \\
\hline $\begin{array}{l}\text { Schwartz, L.M. et al., } \\
\text { 2009[420] }\end{array}$ & Drug facts box & Cardiovascular Health \\
\hline $\begin{array}{l}\text { Schwartz, M.D. et al., } \\
2009[421]\end{array}$ & & Breast Cancer \\
\hline Sepucha et al., 2009[422] & $\begin{array}{l}\text { Living with Metastatic Breast } \\
\text { Cancer: Making the Journey } \\
\text { Your Own }\end{array}$ & Breast Cancer \\
\hline Shaffer et al., 2013[423] & & Breast Cancer \\
\hline Shaw et al., 2001[424] & & Colorectal Cancer \\
\hline Sheppard et al., 2010[425] & & Breast Cancer \\
\hline Sheridan et al., 2004[426] & & Prostate Cancer \\
\hline Sherman et al., 2014[427] & $\begin{array}{l}\text { Breast reconstruction } \\
\text { decision aid (BRECONDA) }\end{array}$ & $\begin{array}{l}\text { Breast Cancer; Ductal } \\
\text { Carcinoma In Situ }\end{array}$ \\
\hline $\begin{array}{l}\text { Shorten et al., 2004[428]; } \\
\text { Shorten et al., 2005[429] }\end{array}$ & & Reproductive Health \\
\hline Simon et al., 2012[430] & Patient Dialogue & $\begin{array}{l}\text { Depression; Acute Low Back } \\
\text { Pain }\end{array}$ \\
\hline $\begin{array}{l}\text { Smith et al., 2008[431]; } \\
\text { Trevena et al., 2008[432]; } \\
\text { Smith et al., 2009[433]; Smith } \\
\text { et al., 2010[434] }\end{array}$ & & Colorectal Cancer \\
\hline Smith et al., 2011[435] & & $\begin{array}{l}\text { Prostate Cancer; Breast } \\
\text { Cancer; Colorectal Cancer; } \\
\text { Lung Cancer }\end{array}$ \\
\hline Solberg et al., 2010[436] & & Reproductive Health \\
\hline Sorenson et al., 2004[437] & & Hemophilia \\
\hline $\begin{array}{l}\text { Spunt et al., 1996[438]; Deyo } \\
\text { et al., 2000[439]; Phelan et } \\
\text { al., 2001[440] }\end{array}$ & & $\begin{array}{l}\text { Low Back Problems } \\
\text { (herniated disks; spinal } \\
\text { stenosis; and other } \\
\text { diagnoses) }\end{array}$ \\
\hline
\end{tabular}




\begin{tabular}{|c|c|c|}
\hline Sridhar et al., 2015[441] & Plan A Birth Control & Reproductive Health \\
\hline Stacey et al., 2003[442] & & Breast Cancer \\
\hline Stacey et al., 2014[443] & $\begin{array}{l}\text { Treatment Choices for Knee } \\
\text { Osteoarthritis }\end{array}$ & Knee Osteoarthritis \\
\hline $\begin{array}{l}\text { Stalmeier \& Roosmalen, } \\
\text { 2009[444] }\end{array}$ & & $\begin{array}{l}\text { Breast Cancer; Ovarian } \\
\text { Cancer }\end{array}$ \\
\hline $\begin{array}{l}\text { Stalmeier \& Roosmalen, } \\
\text { 2009[444] }\end{array}$ & & $\begin{array}{l}\text { Breast Cancer; Ovarian } \\
\text { Cancer }\end{array}$ \\
\hline Stalmeier et al., 1999[445] & & Breast Cancer \\
\hline $\begin{array}{l}\text { Steckelberg et al., 2004[446]; } \\
\text { Steckelberg et al., 2011[447] }\end{array}$ & & Colorectal Cancer \\
\hline Stein et al., 2013[448] & Living with Advanced Cancer & $\begin{array}{l}\text { Advance Care Planning; } \\
\text { Cancer }\end{array}$ \\
\hline Stephens et al., 2008[449] & & Prostate Cancer \\
\hline Stiggelbout et al., 2008[450] & & Abdominal Aortic Aneurysm \\
\hline Stirling et al., 2012[451] & $\begin{array}{l}\text { GOLD Book (Guiding Options } \\
\text { for Living with Dementia) }\end{array}$ & Dementia \\
\hline Street et al., 1995[452] & $\begin{array}{l}\text { Options for Treating Breast } \\
\text { Cancer }\end{array}$ & Breast Cancer \\
\hline Sudore et al., 2014[453] & PREPARE & Advance Care Planning \\
\hline $\begin{array}{l}\text { Sullivan et al., 2007[454]; } \\
\text { McCarthy et al., 2010[455]; } \\
\text { Chambers et al., 2012[456] }\end{array}$ & $\begin{array}{l}\text { Ottawa Influenza Decision } \\
\text { Aid (OIDA) }\end{array}$ & Vaccine-Preventable Disease \\
\hline Sundaresan et al., 2011[457] & & Prostate Cancer \\
\hline $\begin{array}{l}\text { Tan \& Wolfe, 2012[458]; Tan } \\
\& \text { Wolfe, 2014[459] }\end{array}$ & & Psoriasis \\
\hline $\begin{array}{l}\text { Taylor et al., 2006[460]; } \\
\text { Dorfman et al., 2010[461]; } \\
\text { Kassan et al., 2012[462] }\end{array}$ & $\begin{array}{l}\text { Prostate Cancer Screening: } \\
\text { Making an Informed Decision } \\
\text { (one of three patient decision } \\
\text { aids) }\end{array}$ & Prostate Cancer \\
\hline $\begin{array}{l}\text { Taylor et al., 2006[460]; } \\
\text { Dorfman et al., 2010[461]; } \\
\text { Kassan et al., 2012[462]; } \\
\text { Williams et al., 2013[463] }\end{array}$ & $\begin{array}{l}\text { Prostate Cancer Screening: } \\
\text { Making an Informed Decision } \\
\text { (one of three patient decision } \\
\text { aids) }\end{array}$ & Prostate Cancer \\
\hline
\end{tabular}




\begin{tabular}{|c|c|c|}
\hline $\begin{array}{l}\text { Taylor et al., 2006[460]; } \\
\text { Dorfman et al., 2010[461]; } \\
\text { Kassan et al., 2012[462]; } \\
\text { Williams et al., 2013[463]; } \\
\text { Taylor et al., 2013[464] }\end{array}$ & $\begin{array}{l}\text { Prostate Cancer Screening: } \\
\text { Making an Informed Decision } \\
\text { (one of three patient decision } \\
\text { aids) }\end{array}$ & Prostate Cancer \\
\hline Thomas et al., 2013[465] & & Cardiovascular Health \\
\hline $\begin{array}{l}\text { Thomson et al., 2002[466]; } \\
\text { Kaner et al., 2007[467]; } \\
\text { Thomson et al., 2007[468] }\end{array}$ & & Cardiovascular Health \\
\hline $\begin{array}{l}\text { Tiller et al., 2003[469]; Tiller } \\
\text { et al., 2006[470] }\end{array}$ & & Ovarian Cancer \\
\hline Tracy et al., 2004[471] & $\begin{array}{l}\text { Health Care Information } \\
\text { Directive (HCID) }\end{array}$ & $\begin{array}{l}\text { Disclosure of Personal Health } \\
\text { Information }\end{array}$ \\
\hline $\begin{array}{l}\text { van der Krieke et al., } \\
\text { 2012[472] }\end{array}$ & WEGWEIS & Schizophrenia \\
\hline $\begin{array}{l}\text { van Peperstraten et al., } \\
\text { 2010a[473]; van Peperstraten } \\
\text { et al., 2010b[474] }\end{array}$ & & Reproductive Health \\
\hline $\begin{array}{l}\text { van Roosmalen et al., } \\
\text { 2004a[475]; van Roosmalen } \\
\text { et al., 2004b[476] }\end{array}$ & & Breast Cancer \\
\hline $\begin{array}{l}\text { van Steenkiste et al., } \\
2008[477]\end{array}$ & & Cardiovascular Health \\
\hline van Til et al., 2010[478] & & $\begin{array}{l}\text { Ankle-Foot Impairment in } \\
\text { Stroke; Arm-Hand Function in } \\
\text { Cervical Spinal Cord Injury }\end{array}$ \\
\hline $\begin{array}{l}\text { van Tol-Geerdink et al., } \\
\text { 2006[479]; van Tol-Geerdink } \\
\text { et al., 2008[480] }\end{array}$ & & Prostate Cancer \\
\hline $\begin{array}{l}\text { van Tol-Geerdink et al., } \\
\text { 2013[481] }\end{array}$ & & Prostate Cancer \\
\hline van Vugt et al., 2010[482] & & Prostate Cancer \\
\hline $\begin{array}{l}\text { Vandemheen et al., } \\
\text { 2009[483]; Vandemheen et } \\
\text { al., 2010[484] }\end{array}$ & & Cystic Fibrosis \\
\hline Vernon et al., 2011[485] & Screen for Life & Colorectal Cancer \\
\hline Veroff et al., 2012[486] & Living with Heart Failure: & Cardiovascular Health \\
\hline
\end{tabular}




\begin{tabular}{|l|l|l|}
\hline & $\begin{array}{l}\text { Helping your Heart Day-to- } \\
\text { Day }\end{array}$ & \\
\hline Vodermaier et al., 2009[487] & & Breast Cancer \\
\hline Vodermaier et al., 2011[488] & & Breast Cancer \\
\hline Vogel et al., 2013[489] & & $\begin{array}{l}\text { Advance Care Planning; } \\
\text { Ovarian Cancer }\end{array}$ \\
\hline $\begin{array}{l}\text { Volandes et al., 2009a[490]; } \\
\text { Volandes et al., 2009b[491]; }\end{array}$ & & $\begin{array}{l}\text { Advance Care Planning; } \\
\text { Dementia }\end{array}$ \\
\hline $\begin{array}{l}\text { Volk et al., 1999[493]; Volk et } \\
\text { al., 2003[494] }\end{array}$ & $\begin{array}{l}\text { The PSA Decision: What } \\
\text { YOU Need to Know }\end{array}$ & Prostate Cancer \\
\hline Volk et al., 2008[495] & & Prostate Cancer \\
\hline Volk et al., 2014[496] & $\begin{array}{l}\text { Lung Cancer Screening: Is It } \\
\text { Right for Me? }\end{array}$ & Lung Cancer \\
\hline $\begin{array}{l}\text { Vuorma et al., 2003[497]; } \\
\text { Vuorma et al., 2004[498] }\end{array}$ & & Menorrhagia \\
\hline $\begin{array}{l}\text { Wakefield et al., 2007[499]; } \\
\text { Wakefield et al., 2008a[500]; } \\
\text { Wakefield et al., 2008b[501] }\end{array}$ & & Breast Cancer; Ovarian \\
\hline Wakefield et al., 2008[502] & & Cancer; Colorectal Cancer \\
\hline $\begin{array}{l}\text { Wakefield et al., 2011[503]; } \\
\text { Watts et al., 2014[504] }\end{array}$ & & Colorectal Cancer \\
\hline Wall, 1985[505] & & Prostate Cancer \\
\hline Wang et al., 2005[506] & & Reproductive Health \\
\hline Watson et al., 2006[507] & $\begin{array}{l}\text { PSA Testing for Prostate } \\
\text { fancer- an information sheet } \\
\text { for men considering a PSA }\end{array}$ & Prostate Cancer \\
\hline Weinrich et al., 2008[508] & Your life-You decide & Prostate Cancer \\
\hline Weng et al., 2007[509] & & Knee Osteoarthritis \\
\hline Westreich et al., 1995[510] & & Mental Health \\
\hline Weyand et al., 2011[511] & & Neonatal Intensive Care \\
\hline
\end{tabular}




\begin{tabular}{|c|c|c|}
\hline $\begin{array}{l}\text { Whelan et al., 1995[512]; } \\
\text { Whelan et al., 1999[513]; } \\
\text { Whelan et al., 2003[514]; } \\
\text { Whelan et al., 2004[515] }\end{array}$ & Decision Board & Breast Cancer \\
\hline Whiskey \& Taylor, 2005[516] & & Mental Health \\
\hline Wilkins et al., 2006[517] & $\begin{array}{l}\text { Early Stage Breast Cancer: } \\
\text { Choosing Your Surgery }\end{array}$ & Breast Cancer \\
\hline Willemsen et al., 2006[518] & & Smoking \\
\hline Wilson et al., 2015[519] & & $\begin{array}{l}\text { Intensive Care Unit; } \\
\text { Cardiovascular Health }\end{array}$ \\
\hline Wilt et al., 2000[520] & Early prostate cancer & Prostate Cancer \\
\hline Wolf \& Schorling, 2000[521] & & Colorectal Cancer \\
\hline $\begin{array}{l}\text { Wolf et al., 1996[522]; Wolf \& } \\
\text { Schorling, 1998[523] }\end{array}$ & & Prostate Cancer \\
\hline Woltmann et al., 2011[524] & & Mental Health \\
\hline Wong et al., 2006[525] & & Reproductive Health \\
\hline Wong et al., 2012[526] & & Breast Cancer \\
\hline $\begin{array}{l}\text { Wright et al., 2002[527]; } \\
\text { Wright et al., 2004[528] }\end{array}$ & $\begin{array}{l}\text { Interactive Decision Explorer } \\
\text { (IDEX) }\end{array}$ & Cardiovascular Health \\
\hline Wroe et al., 2005[529] & $\begin{array}{l}\text { Deciding about } \\
\text { Immunizations: The benefits } \\
\text { and the risks. }\end{array}$ & Vaccine-Preventable Disease \\
\hline Yun et al., 2011[530] & $\begin{array}{l}\text { Patients Want to Know the } \\
\text { Truth }\end{array}$ & $\begin{array}{l}\text { Advance Care Planning; } \\
\text { Cancer }\end{array}$ \\
\hline Zapka et al., 2004[531] & Say Yes to the Test & Colorectal Cancer \\
\hline Zeliadt et al., 2013[532] & $\begin{array}{l}\text { Making the Choice: Deciding } \\
\text { What to Do About Early } \\
\text { Stage Prostate Cancer }\end{array}$ & Prostate Cancer \\
\hline
\end{tabular}

Table 2. Included User-Centered Design Projects

\begin{tabular}{|l|l|l|}
\hline Articles in this project & $\begin{array}{l}\text { Patient-centered tool name } \\
\text { (if exists) }\end{array}$ & Clinical context \\
\hline Adamo-Villani, 2007[533] & & Deafness \\
\hline
\end{tabular}




\begin{tabular}{|l|l|l|}
\hline $\begin{array}{l}\text { Ahlers-Schmidt et al., } \\
\text { 2011[534]; Hart et al., } \\
\text { 2011535]; Ahlers-Schmidt et } \\
\text { al., 2012a[536]; Ahlers- } \\
\text { Schmidt et al., 2012b[537]; } \\
\text { Ahlers-Schmidt et al., } \\
\text { 2012c[538]; Ahlers-Schmidt } \\
\text { et al., 2013[539] }\end{array}$ & & Vaccine-Preventable Disease \\
\hline Al-Abdullatif et al., 2013[540] & $\begin{array}{l}\text { Arabic Brain Communicator } \\
\text { (ABC) }\end{array}$ & \\
\hline Amiri et al., 2012[541] & & Disability \\
\hline $\begin{array}{l}\text { Atkinson et al., 2007[542]; } \\
\text { Atkinson et al., 2009[543]; } \\
\text { Atkinson et al., 2010[544] }\end{array}$ & & Physical Injury \\
\hline Bae et al., 2009[545] & & Obesity; Physical Activity; \\
\hline Cafazzo et al., 2012[546] & bant & Nutrition \\
\hline Carey-Smith et al., 2013[547] & & Depression \\
\hline Cavallo et al., 2013[548] & ASTROMOBILE & Diabetes \\
\hline $\begin{array}{l}\text { Civan \& Pratt, 2007[549]; } \\
\text { Civan-Hartzler et al., } \\
\text { 2010[550] }\end{array}$ & & Elderly \\
\hline Cofré et al., 2012[38] & & Elderly \\
\hline Dabbs et al., 2009[551] & Pocket Personal Assistant for & Lung Transplant \\
\hline Das \& Svanoes, 2013[552] & PATH) Health (Pocket & Breast Cancer; Cancer \\
\hline $\begin{array}{l}\text { Faraji \& Farahmand, } \\
\text { 2014[553] }\end{array}$ & & Obesity \\
\hline Felice et al., 2007[554] & The e-LIS dictionary & Work-Related \\
\hline $\begin{array}{l}\text { Fico et al., 2010[555]; Fico et } \\
\text { al., 2011[18] }\end{array}$ & METABO system & Deafness \\
\hline Fonda et al., 2010[17] & & Diabetes \\
\hline Gilliam et al., 2014[556] & & Disability \\
\hline Harada et al., 2007[557] & VoiceDraw & \\
\hline
\end{tabular}




\begin{tabular}{|l|l|l|}
\hline Hawley et al., 2013[39] & $\begin{array}{l}\text { Voice-input voice-output } \\
\text { communication aid (VIVOCA) }\end{array}$ & $\begin{array}{l}\text { Dysarthria (speech } \\
\text { impairment) }\end{array}$ \\
\hline Herschman et al., 2014[558] & & Lupus \\
\hline $\begin{array}{l}\text { Izard et al., 2014[559]; } \\
\text { Hartzler et al., 2016[560] }\end{array}$ & & Prostate Cancer \\
\hline Jia et al., 2013[561] & & Cardiovascular Health \\
\hline Johnston et al., 2009[562] & & $\begin{array}{l}\text { Chronic Obstructive } \\
\text { Pulmonary Disorder }\end{array}$ \\
\hline Lalji \& Good, 2008[563] & & Illiteracy \\
\hline $\begin{array}{l}\text { Lepicard et al., 2007a[564]; } \\
\text { Lepicard et al., 2007b[565] }\end{array}$ & Virtual Paddle & Disability \\
\hline $\begin{array}{l}\text { Lewis et al., 2000[566]; } \\
\text { Shopland et al., 2005[567] }\end{array}$ & Virtual City & Learning Disability \\
\hline Limbach, 2012[568] & The MeMoTray & Dementia \\
\hline Ma et al., 2007[569] & & Hemiplegia \\
\hline MacCallum et al., 2013[570] & Know Your Colours & Cardiovascular Health \\
\hline Marcu et al., 2012[571] & MONARCA system & Bipolar Disorder \\
\hline Markopoulos et al., 2011[572] & Us'em & $\begin{array}{l}\text { Cardiovascular Health; } \\
\text { Impaired Limbs (post-stroke) }\end{array}$ \\
\hline Marti \& Giusti, 2010[573] & Iromec & $\begin{array}{l}\text { Autism Spectrum Disorder; } \\
\text { Intellectual Disability; } \\
\text { Physical Impairment }\end{array}$ \\
\hline $\begin{array}{l}\text { Massoudi et al., 2010[574]; } \\
\text { Olmsted et al., 2015[575] }\end{array}$ & & Physical Activity \\
\hline $\begin{array}{l}\text { Mawson et al., 2014[576]; } \\
\text { Parker et al., 2014[577] }\end{array}$ & $\begin{array}{l}\text { Personalised Self-Managed } \\
\text { Rehabilitation System } \\
\text { (PSMrS) }\end{array}$ & Cardiovascular Health \\
\hline McDaniel et al., 2005[15] & & Autism Spectrum Disorder \\
\hline McGaffey et al., 2010[578] & The Fitwits School program & Obesity \\
\hline Munoz et al., 2012[579] & & Autism Spectrum Disorder \\
\hline Nasir et al., 2008[580] & & Cardiovascular Health \\
\hline Neale et al., 2002[581] & & Smoking \\
\hline
\end{tabular}




\begin{tabular}{|l|l|l|}
\hline Nordfeldt et al., 2007[16] & DiablT simulator & Diabetes \\
\hline $\begin{array}{l}\text { Osborn \& Mulvaney, } \\
\text { 2013[582] }\end{array}$ & $\begin{array}{l}\text { MEssaging for Diabetes } \\
\text { (MED) intervention }\end{array}$ & Diabetes \\
\hline $\begin{array}{l}\text { Peters et al., 2004[583]; } \\
\text { Mancas-Thillou et al., } \\
\text { 2007[584] }\end{array}$ & SYPOLE & Blindness \\
\hline Petrie et al., 1997[585] & the MoBIC Travel Aid (MoTA) & Blindness \\
\hline Pigini et al., 2012[586] & & Elderly \\
\hline $\begin{array}{l}\text { Rizzo et al., 2009[587]; Rizzo } \\
\text { et al., 2010[588] }\end{array}$ & Virtual Iraq/Afghanistan & $\begin{array}{l}\text { Post-Traumatic Stress } \\
\text { Disorder }\end{array}$ \\
\hline Robinson et al., 2009[589] & $\begin{array}{l}\text { Keep in Touch Everyday } \\
\text { (KITE) }\end{array}$ & Dementia \\
\hline Sanchez \& Flores, 2008[590] & AudiodMC & Blindness \\
\hline $\begin{array}{l}\text { Sanchez-Morillo et al., } \\
\text { 2015a[591]; Sanchez-Morillo } \\
\text { et al., 2015b[592] }\end{array}$ & $\begin{array}{l}\text { AMICA (Autonomy Motivation } \\
\text { \& Individual Self- } \\
\text { Management for COPD } \\
\text { patients) }\end{array}$ & $\begin{array}{l}\text { Chronic Obstructive } \\
\text { Pulmonary Disorder }\end{array}$ \\
\hline $\begin{array}{l}\text { Siek et al., 2006[593]; } \\
\text { Connelly et al., 2012[594] }\end{array}$ & $\begin{array}{l}\text { Dietary Intake Monitoring } \\
\text { Application (DIMA) }\end{array}$ & $\begin{array}{l}\text { Patients Receiving } \\
\text { Hemodialysis }\end{array}$ \\
\hline Slagle et al., 2010[595] & MyMediHealth & Medication \\
\hline Stinson et al., 2014[596] & iCanCope with Pain & Chronic Pain \\
\hline Taylor et al., 2003[597] & & Amblyopia \\
\hline $\begin{array}{l}\text { van der Weegen et al.,, } \\
\text { 2013[598]; Verwey et al., } \\
\text { 2014[599] }\end{array}$ & It's Life! & $\begin{array}{l}\text { Diabetes; Chronic } \\
\text { Obstructive Pulmonary } \\
\text { Disorder; Chronic Disease(s) }\end{array}$ \\
\hline $\begin{array}{l}\text { Verdezoto \& Grönvall, } \\
\text { 2012[600]; Verdezoto \& Wolff } \\
\text { Olsen, 2012[601]; Dalgaard } \\
\text { et al., 2013[602] }\end{array}$ & MediFrame & $\begin{array}{l}\text { Older Adults Medication } \\
\text { Intake }\end{array}$ \\
\hline Verhoeven et al., 2010[603] & & Cerebral Palsy \\
\hline $\begin{array}{l}\text { Vermeulen et al., 2013[604] } \\
\text { Weightman et al., 2010[20] }\end{array}$ & & Vaccine-Preventable Disease \\
\hline
\end{tabular}




\begin{tabular}{|l|l|l|}
\hline Wentz et al., 2012[606] & SalutChat & $\begin{array}{l}\text { Autism Spectrum Disorder; } \\
\text { Attention Deficit Hyperactivity } \\
\text { Disorder }\end{array}$ \\
\hline Wolpin et al., 2015[607] & $\begin{array}{l}\text { Electronic Self-Report } \\
\text { Assessment for Cancer } \\
\text { (ESRAC) }\end{array}$ & Cancer \\
\hline Wu et al., 2009[608] & & Disability \\
\hline $\begin{array}{l}\text { Yu et al., 2014a[609]; Yu et } \\
\text { al., 2014b[610] }\end{array}$ & Diabetes Online Companion & Diabetes \\
\hline Zhang et al., 2008[611] & CogKnow navigator & Dementia \\
\hline $\begin{array}{l}\text { Zickler et al., 2013[19]; } \\
\text { Höhne et al., 2014[612]; } \\
\text { Botrel et al., 2015[613] }\end{array}$ & Brain Painting & $\begin{array}{l}\text { Disability; Hemiplegia; } \\
\text { Tetraplegia; Amyotrophic } \\
\text { Lateral Sclerosis }\end{array}$ \\
\hline
\end{tabular}

Data quality assessment

The quality of studies is summarized in Appendix 3. Overall, quality was acceptable, though with some weaknesses in evaluation studies, such as low rates of controlling of potentially confounding variables in non-experimental studies.

\section{Data validation}

Two hundred thirty four project authors $(60 \%)$ responded to validate or correct data. Within those projects, authors' comments changed $4.3 \%$ of all extracted data. This $4.3 \%$ consisted of $2.7 \%$ for addition of previously missing data, $0.05 \%$ for precision of data, $0.2 \%$ for correction of incorrect data, and $1.3 \%$ for differences that did not materially affect the extracted data.

\section{Project and tool characteristics}

Overall, projects were reported in articles published from 1976 to 2016. Patient decision aid publications dated from 1976 and user-centered design publications from 1997. Half of patient decision aid projects $(51 \%)$ cited no theory, model, framework, or standards. The two most commonly cited such foundations were the International Patient Decision Aid Standards (19\%) and the Ottawa Decision Support Framework (17\%).

Among the 325 patient decision aids, $61 \%$ were paper based. The most common clinical contexts addressed were breast cancer $(20 \%)$ and reproductive health $(19 \%)$ and the most common purposes were to support a treatment $(57 \%)$ or screening $(21 \%)$ decision. Regarding intended context of use, almost half of the patient decision aids (46\%) were designed for use at home or in a private setting. Regarding timing of use, many were designed to be used before $(38 \%)$, during $(31 \%)$ or between $(23 \%)$ clinical encounters. 
Among the 65 other health tools developed via user-centered design, $42 \%$ used an online application format. The most common clinical contexts addressed were disabilities $(25 \%)$ and the most common purposes were to support everyday activities $(45 \%)$ or other activities such as monitoring, self-management or self-monitoring (40\%). The majority of tools $(68 \%)$ were designed to be used in an everyday context, wherever the person happened to be. Regarding timing of tool usage, many tools (34\%) were not associated with clinical encounters.

\section{Development steps, overall and by user-centered design element}

In the following sections, we present (1) the frequency with which a development step was reported out of all projects, with or without user involvement, (2) the frequency with which a development step was reported with users involved in some way, and (3) the number of reported users involved in development steps. For this latter reporting element, because many projects did not report the numbers of users involved in any development step, we present data only from projects in which a specific number of users was reported. In other words, when we report the median number of users involved in particular development steps, this is the median only among projects that reported how many users were involved.

\section{Overall}

Among projects that described at least one development step ( $n=348), 89 \%$ reported at least one step to do with understanding users, $91 \%$ with developing/refining prototype, and $93 \%$ with observing users interacting with the prototype.

Patient decision aid projects with at least one step of development $(n=283)$ reported a median of 5 steps (interquartile range 4-7, full range 1-11) of the 12 predefined development steps within our user-centered design framework. User-centered design projects $(n=65)$ reported a median of 6 steps (interquartile range 4-8, full range 2-12). Out of 12 possible development steps in total, patient decision aid projects reported involving users in a median of 2 steps (interquartile range 1-3, full range 0-7) while user-centered design projects reported involving users in a median of 3 steps (interquartile range 2-5, full range $0-8$ ). Out of all 348 projects that described development, 261 reported a specific number of users involved in one or more of the 12 predefined steps and up to 4 other steps. Within these 261 projects, 201 patient decision aid projects involved a median of 39 users (interquartile range 23-82, full range 1-1210) and 60 user-centered design projects involved a median of 35 users (interquartile range 16-65, full range 2-3770). Tables 3 and 4 provide further details of the percent of projects that reported each step, involved users in each step, and the numbers of users involved.

Table 3. Development steps: steps and users' involvement

\begin{tabular}{|l|l|l|l|l|}
\hline & \multicolumn{2}{|l|}{ Development steps reported } & \multicolumn{2}{l|}{$\begin{array}{l}\text { Users reported as being } \\
\text { involvement in step(s) }\end{array}$} \\
\hline & $\begin{array}{l}\text { Patient } \\
\text { decision aid }\end{array}$ & $\begin{array}{l}\text { User-centered } \\
\text { design }\end{array}$ & $\begin{array}{l}\text { Patient } \\
\text { decision aid }\end{array}$ & $\begin{array}{l}\text { User-centered } \\
\text { design }\end{array}$ \\
\hline
\end{tabular}




\begin{tabular}{|c|c|c|c|c|}
\hline & \begin{tabular}{|l} 
projects \\
$(n=283)$ \\
$\mathrm{n}(\%)$
\end{tabular} & \begin{tabular}{|l} 
projects \\
$(n=65)$ \\
$n(\%)$
\end{tabular} & \begin{tabular}{|l} 
projects \\
$(\mathrm{n}=283)$ \\
$\mathrm{n}(\%)$
\end{tabular} & \begin{tabular}{|l} 
projects \\
$(\mathrm{n}=65)$ \\
$\mathrm{n}(\%)$
\end{tabular} \\
\hline \multicolumn{5}{|l|}{ Understanding user } \\
\hline Literature review & $230(81 \%)$ & $41(63 \%)$ & $5(2 \%)$ & $0(0 \%)$ \\
\hline $\begin{array}{l}\text { Observation of existing } \\
\text { processes (e.g., ethnography) }\end{array}$ & $35(12 \%)$ & $30(46 \%)$ & $18(6 \%)$ & $27(42 \%)$ \\
\hline Formal needs assessment & $43(15 \%)$ & $23(35 \%)$ & $38(13 \%)$ & $22(34 \%)$ \\
\hline Informal needs assessment & $133(47 \%)$ & $47(72 \%)$ & $110(39 \%)$ & $42(65 \%)$ \\
\hline \multicolumn{5}{|l|}{ Developing/refining prototype } \\
\hline $\begin{array}{l}\text { Develop and/or validate } \\
\text { underlying model }\end{array}$ & $47(17 \%)$ & $3(5 \%)$ & $0(0 \%)$ & $0(0 \%)$ \\
\hline Storyboarding/wireframing & $69(24 \%)$ & $39(60 \%)$ & $11(4 \%)$ & $13(20 \%)$ \\
\hline Adapt/translate tool & $95(34 \%)$ & $12(18 \%)$ & $4(1 \%)$ & $0(0 \%)$ \\
\hline $\begin{array}{l}\text { Content/format review prior to } \\
\text { prototyping }\end{array}$ & $157(55 \%)$ & $33(51 \%)$ & $48(17 \%)$ & $21(32 \%)$ \\
\hline Prototype development & $248(88 \%)$ & $62(95 \%)$ & $53(19 \%)$ & $9(14 \%)$ \\
\hline \multicolumn{5}{|c|}{ Observing prospective user's interaction with prototype } \\
\hline Content/format review after & $189(67 \%)$ & $33(51 \%)$ & $101(36 \%)$ & $24(37 \%)$ \\
\hline Pilot/usability testing & $231(82 \%)$ & $58(89 \%)$ & $208(73 \%)$ & $58(89 \%)$ \\
\hline Second pilot/usability testing & $32(11 \%)$ & $12(18 \%)$ & $29(10 \%)$ & $9(14 \%)$ \\
\hline
\end{tabular}

Table 4. Development steps: numbers of users involved

\begin{tabular}{|l|l|l|}
\hline \multicolumn{2}{|l|}{} & $\begin{array}{l}\text { Number of users involved in the step(s), when numbers of } \\
\text { users were reported }\end{array}$ \\
\hline & $\begin{array}{l}\text { Patient decision aid projects: } \\
\text { Median (IQR) (Range) } \\
\text { (n/283) }\end{array}$ & $\begin{array}{l}\text { User-centered design } \\
\text { projects: Median (IQR) } \\
\text { (Range) (n/65) }\end{array}$ \\
\hline Understanding user & - & - \\
\hline Literature review & - & \\
\hline
\end{tabular}




\begin{tabular}{|l|l|l|}
\hline $\begin{array}{l}\text { Observation of existing } \\
\text { processes (e.g., ethnography) }\end{array}$ & $36(12-56)(4-605)(n=9)$ & $13(9-18)(1-100)(n=10)$ \\
\hline Formal needs assessment & $24(16-44)(8-400)(n=24)$ & $20(15-23)(8-3710)(n=13)$ \\
\hline Informal needs assessment & $30(15-43)(3-1119)(n=38)$ & $18(9-33)(1-325)(n=22)$ \\
\hline Developing/refining prototype & - & - \\
\hline $\begin{array}{l}\text { Develop and/or validate } \\
\text { underlying model }\end{array}$ & - & $10(5-13)(2-18)(n=7)$ \\
\hline Storyboarding/wireframing & $35(33-38)(30-40)(n=2)$ & - \\
\hline Adapt/translate tool & $14(8-25)(2-153)(n=16)$ & $16(15-18)(5-20)(n=8)$ \\
\hline $\begin{array}{l}\text { Content/format review prior to } \\
\text { prototyping }\end{array}$ & $10(6-26)(1-44)(n=14)$ & $10(2-11)(1-44)(n=5)$ \\
\hline Prototype development & $20(9-30)(1-90)(n=61)$ & $8(7-10)(4-23)(n=14)$ \\
\hline Observing prospective user's interaction with prototype & $17(12-40)(7-188)(n=26)$ & $6(4-13)(1-18)(n=7)$ \\
\hline Content/format review after & $28(1-45)(1-605)(n=161)$ & $12(n=49)$ \\
\hline Pilot/usability testing & Second pilot/usability testing & $17202)$ \\
\hline
\end{tabular}

IQR: InterQuartile Range 


\section{Iteration}

Most projects reported iterative development processes $(74 \%$ of patient decision aid projects, $92 \%$ of user-centered design projects). The median numbers of iterative cycles was 3 (interquartile range: 2-4) for patient decision aids and 3 (interquartile range: 2-3) for usercentered design of other patient-centered tools. Changes between versions of prototypes were described in $23 \%$ of reports of patient decision aid projects and $52 \%$ of reports of user-centered design projects.

\section{Users involved}

Primary users: patients, family members, caregivers, surrogates

Most patient decision aid projects (95\%) and user-centered design projects (98\%) reported involving individuals who previously, currently, or potentially will face the health issue. The majority of these users were reported as currently facing the health issue $(85 \%$ for patient decision aid projects and $94 \%$ for user-centered design projects). Surrogate decision-makers were involved in $2 \%$ of patient decision aid projects and $0 \%$ of user-centered design projects. Caregivers and family members or friends were involved in $5 \%$ and $11 \%$ of patient decision aid projects, respectively, and $22 \%$ and $20 \%$ of user-centered design projects. As we reported elsewhere, $16 \%$ of patient decision aid projects specifically involved members of vulnerable populations in the development process [29].

\section{Clinician users}

Many patient decision aid projects $(63 \%)$ and user-centered design projects $(55 \%)$ reported involving clinician users, meaning health care professionals who might interact with the tools in different ways than primary users. The median numbers of clinician users involved in total were 10 (interquartile range: 5-22) and 9 (interquartile range: 4-20), respectively. Clinician user involvement was typically not reported with the same level of detail as primary user involvement. Teams consulted clinician users mainly before developing a first prototype (64\% patient decision aid projects, $64 \%$ user-centered design projects) and/or between prototype versions (69\% patient decision aid projects, $53 \%$ user-centered design projects). The majority of projects reported changing the tool based on clinicians' feedback (73\% patient decision aid projects, $72 \%$ user-centered design projects).

\section{Advisory panels, organizations, and expert panels}

Nine percent of patient decision aid projects and $6 \%$ of user-centered design projects reported working with a formal patient, family, caregiver or surrogate user advisory panel. In addition, in patient decision aid and user-centered design projects, $12 \%$ and $14 \%$, respectively, reported working with at least one formal, named patient organization, and $2 \%$ in each group reported with at least one formal, named health professional organization. Other types of experts were more involved, namely, $47 \%$ of patient decision aid projects and $38 \%$ of user-centered design projects reported engaging an expert panel that might include academic researchers, health 
professionals, and experts in other areas (e.g., plain language experts, web developers, designers).

\section{Recruitment and compensation}

The majority ( $82 \%$ ) of patient decision aid projects recruited convenience samples of primary users. About half $(55 \%)$ of user-centered design projects recruited primary users with this method. Five percent of patient decision aid projects did not report how they recruited primary users; $32 \%$ of user-centered design projects did not report recruitment methods.

Primary users were compensated in around one quarter of each kind of projects, with $27 \%$ of patient decision aid projects and $26 \%$ of user-centered design projects. Cash was the most common form of compensation. Cash was used in $19 \%$ of patient decision aid and $12 \%$ of usercentered design projects.

\section{Individual or group involvement}

For content and format reviews before and after the prototype development, projects reported involving primary users in groups; for example, in focus groups $(20 \%$ for patient decision aid projects, $25 \%$ for user-centered design projects). Otherwise, users were typically involved individually; for example, in interviews.

\section{Degree of involvement}

Primary users were reported as being involved as participants in studies in nearly every project (over $99 \%$ of patient decision aid projects; $97 \%$ of user-centered design projects). They were sometimes reported as being involved in an advisory capacity (27\% patient decision aid projects versus $22 \%$ user-centered design projects). Fewer projects reported involving users on an advisory panel ( $9 \%$ versus $6 \%$ ) or as partners on the research or development team ( $8 \%$ versus $14 \%)$.

\section{Methods of eliciting users' responses to the tool}

User-centered design methods often include direct observation of users (e.g., ethnographic observation prior to developing a tool, conducting usability testing with methods such as think aloud) whereas more traditional health services research tend towards asking users their opinions (e.g., focus groups, interviews, surveys) and assessing the effects of a tool on users (e.g., testing knowledge and decisional conflict in pre-post studies or randomized controlled trials). Therefore, in addition to the mode of involvement, we also observed the nature of involvement.

A large majority of patient decision aid projects (75\%) and user-centered design projects (94\%) reported asking users their thoughts and opinions of a tool. Forty-one percent of patient decision aid projects and $72 \%$ of user-centered design projects reported observing users interacting with the tool. Eighty-eight percent of patient decision aid projects and $45 \%$ of user-centered design projects reported assessing the impact of the tool on users. 


\section{Evaluation}

In capturing data about what tools had been evaluated, we first determined whether projects assessed any preliminary metrics such as feasibility, acceptability, satisfaction with the tool, usability, or other metrics typically measured before launching a trial or product. Sixty-six percent of patient decision aid projects reported conducting this type of evaluation of preliminary metrics as did $89 \%$ of user-centered design projects. We then determined whether the project had conducted any evaluation of the efficacy of the tool (for example, via an explanatory randomized controlled trial) or the effectiveness of the tool (for example, via a pragmatic trial). Eighty-nine percent of patient decision aid projects reported conducting this type of efficacy or effectiveness evaluation, as did $45 \%$ of user-centered design projects. Finally, we determined whether projects assessed the implementation of tools in any way, including their integration into routine care, barriers and facilitators to usage, uptake, and usage statistics. Nine percent of patient decision aid projects and $12 \%$ of user-centered design projects reported having evaluated the implementation of tools.

\section{Discussion}

\section{Principal results}

Overall, these results suggest that many patient decision aid projects use elements of usercentered design, such as involving users in developing and pilot-testing prototypes. However, additional opportunities remain to better adapt tools to users rather than requiring that users adapt to tools. We suggest four key opportunities for learning and improvement of development processes.

First, developers could involve users in more steps to understand their needs, goals, strengths, limitations, contexts, and intuitive processes prior to developing their tool. This may help address the known gap in the implementation of decision aids by more fully adapting the tools to the people who will use them. Specifically, projects may benefit from engaging in formal or informal needs assessments, and by directly observing existing processes; for example, using ethnographic methods, prior to developing any content or specifying format.

Second, it is important to recognize the different data that one gets from asking users to comment on a prototype, observing users' interactions with the prototype, and assessing the impact of a tool among users. Patient decision aid projects may benefit from using methods of asking and observing that help to optimize user experience. User-centered design projects may also benefit from more formal assessment of impact.

Third, both patient decision aid projects and user-centered design projects demonstrated iterativity, but user-centered design projects more commonly explicitly reported changes between iterative cycles. Patient decision aid developers may wish to consider doing the same. Reporting on changes between versions serves multiple purposes. It provides a record of concepts and ideas that have been attempted and how users responded to them, helps explain 
the design rationale for the final version, and incentivizes rigorous iterative practices in which teams make efficient use of users' time and expertise.

Finally, there may be room for all projects to involve users and clinician users more. Relatively few projects reported involving users in advisory or partnership roles. Patient participation and engagement in research teams has been recently encouraged and required by national funding bodies in the US and elsewhere [30-32]. As partnerships take time to build, our systematic review of the existing literature might simply be too early to observe the effects of these initiatives. More user-centered design projects reported users being members of the team, suggesting that such collaboration and sharing of power is more common in that tradition and may be worth considering in patient decision aid projects as well.

\section{Comparison to previous literature}

To the best of our knowledge, there are no previous systematic reviews of development methods of patient decision aids, nor of the application of user-centered design to patient decision aid development. Our work was responding to a call for more information on usercentered design for patient decision aid development in the most recent update of the International Patient Decision Aid Standards [33-35]. However, situating our work in the broader literature, we offer two main observations.

Our finding that patient decision aids were predominantly intended to be used in or around a clinical encounter aligns with previous literature that already characterized patient decision aids as tools to help patients make specific choices about their health [3] and to encourage them to participate in the shared decision making process with health professionals [36,37]. As methods of delivering patient decision aids increase; for example, via patient portals to electronic health records, it may be worth considering whether tools that are explicitly designed to be used outside the clinical encounter ought to be considered separately from those explicitly designed to be used within the encounter. Similarly, our finding that other patient-centered tools developed using user-centered design included many tools intended to be used everyday reflects authors' characterizations of such tools as "real" tools for everyday lives [38-40].

Our findings about variations in development methods, particularly the way in which usercentered design projects may involve users more often and earlier, aligns with definitions and standards of user-centered design specifying that such a process must incorporate users' needs early and throughout an iterative development process [5,9]. In contrast, standards for patient decision aid development have thus far been less prescriptive regarding the way and frequency with which users must be involved [33,34].

Finally, our study adds to literature from fields such as human factors, human-computer interaction, ergonomics, design, and others that aim to adapt tools to the people who will use them $[5,7,9,21-23]$ by explicitly structuring such processes for patient decision aid development. Some evidence suggests that involving users in the development of health care or healthrelated tools may lead to more usable, accepted, or effective tools $[41,42]$. Improving our understanding of users' needs, goals, strengths, limitations, contexts, and intuitive processes to 
inform the development of patient decision aids may offer additional gains toward supporting evidence-informed health decisions aligned with what matters to those most affected by the decision.

\section{Limitations}

Our review has three main limitations. First, like all systematic reviews of the literature, our original data were limited to what was reported in publications. This limitation may be especially important in our review given we were seeking data about development processes, which are reported in different ways and sometimes with unclear or minimal details. It is possible that in some cases, project teams undertook a development step or involved users without reporting it. We chose to require explicit reporting of steps and user involvement because we posit that when authors take methodological steps seriously, they are more likely to ensure that such steps are reflected in publications about their project. We deliberately used an expansive search strategy and made concerted efforts to contact all authors to maximize opportunities to capture all relevant data. Analyses of authors' responses for $60 \%$ of projects suggested very low rates of data omission or error in our data extraction process. However, we cannot be certain that the low rates of omission or error observed in these projects also apply to the other $40 \%$.

Second, our results may reflect differences between the purposes of tools. User-centered design has been applied more in cases such as a person using a wheelchair or navigating a website. In such cases, the user's interaction with the tool is likely easier for the user to report through methods such as think aloud and also easier for a designer or researcher to observe directly. Patient decision aids, on the other hand, are designed to facilitate interactions such as learning and decision making that are largely internal and whose processes may be difficult to articulate or to observe directly.

Lastly, although it is reasonable to suggest that user-centered design methods may help ensure that tools like patient decision aids are well-adapted to their intended users, this study was not intended to evaluate the quality of development processes of patient decision aids, only to describe them. This work is intended to help situate development processes observed within patient decision aid projects and user-centred design projects in relation to each other in order to identify potential areas of improvement. We note that even among user-centered design projects, users were not involved to the maximum extent. It may be that there is a threshold of involvement that optimizes a tool for use while respecting limited resources such as users' time, developers' time, and funds for development.

\section{Conclusions}

Patient decision aid projects and user-centered design projects show differing patterns of involving users during their development processes, especially regarding the stage, the methods of eliciting users' responses to the tool, and the timing of users' involvement. Some of these reported differences reflect differences between the types and purposes of tools and traditions in different domains. Other differences offer opportunities for learning and 
improvement. Patient decision aid developers may wish to engage in formal or informal needs assessments, ask about and observe user experience, and explicitly report changes between iterations. All who develop patient-centered tools, whether relevant to a health decision or not, may wish to involve users and clinician users in co-design of prototypes, in advisory and partnership roles, and better report on such involvement. Improving our understanding of how to optimize user involvement will serve to better adapt all tools to the people who will use them. 


\section{APPENDICES}

Appendix 1. Search strategy

Appendix 2. Data extraction form

Appendix 3. Full details of study quality, data and analyses

Appendix 4. PRISMA 2009 Checklist

\section{DECLARATIONS}

\section{Abbreviations}

None

\section{Ethics Approval, Consent to Participate and Consent for Publication}

Not applicable.

\section{Availability of Data and Materials}

The data files used in the analyses described in this paper may be accessed at: $\{$ link to be added to accepted version\} for the primary analyses and \{link to be added to accepted version\} for quality assessment data. An R Markdown document accompanies the data at \{link to be added to accepted version\} and provides code for all descriptive analyses described here.

\section{Competing Interests}

During the course of this project, CAL (see Acknowledgements) received salary support as Research Director for the Informed Medical Decisions Foundation, the research division of Healthwise, Inc., a not-for-profit organization (http://www.informedmedicaldecisions.org). Healthwise produces solutions to deliver consistent health content and patient education (including patient decision aids) to various health-care organizations.

\section{Funding}

This study was funded by the Patient-Centered Outcomes Research Institute (PCORI): ME1306-03174. PCORI had no role in determining the study design, the plans for data collection or analysis, the decision to publish, nor the preparation of this manuscript. NMI is funded by a New Investigator Award by the Canadian Institutes of Health Research as well as a New Investigator Award from the Department of Family and Community Medicine, University of Toronto. FL is funded by a Tier 1 Canada Research Chair in Shared Decision Making and Knowledge Translation. DS holds a University of Ottawa Research Chair in Knowledge Translation to 
Patients. HOW is funded by a Research Scholar Junior 1 Career Development Award by the Fonds de Recherche du Québec-Santé.

\section{Authors' Contributions}

Conceptualization and methodology: GV, TP, MD, MET, SCD, HC, AF, AMCG, LH, ASH, NMI, ASJ, FL, CAL, JSR, DS, RJV, HOW; Formal analysis: GV, ASJ, HOW; Investigation: GV, TP, MD, MET, SCD, HH, HOW; Resources: HOW; Data curation: GV, TP, HOW; Writing - Original Draft: GV, TP, HOW; Writing - Review and editing: GV, TP, MD, MET, SCD, HC, AF, AMCG, $\mathrm{HH}$, LH, ASH, NMI, ASJ, FL, CAL, JSR, DS, RJV, HOW; Visualization: GV, TP, HOW; Supervision: HOW; Project administration: GV, SCD, HOW; Funding acquisition: HOW. Contributions are reported according to the CRediT taxonomy [43]. Specific systematic review roles: record screening: GV, TP, MD, MET plus research assistants/associates EB, IB (see Acknowledgements); data extraction: GV, TP, MD, MET plus research associate EB; data validation: $\mathrm{HH}$; adjudication: SCD, HOW; project steering committee: AF, AMCG, SG, FL, KS, RJV, HOW.

\section{Acknowledgements}

The authors gratefully acknowledge the contributions of librarians William Witteman, MIS, for creating the search strategies for this work and Marina Enkelsakis, MLIS, and Michelle Fiander, MA MLIS, for their expertise in peer-reviewing the search strategies. We also thank research assistants Issa Bado and Virginie Sirois, and research associates Erik Breton and Elizabeth Parent for their contributions to screening, data extraction, data validation, and preparation of figures. We thank experts Vincent Dumez, Glyn Elwyn, Margaret Holmes Rovner, Lisa Marsch, Lewis Morgenstern, David Rovner, Corey A. Siegel, Diana Stilwell, Lyndal Trevena, and other experts who contributed valuable expertise to help us refine our data extraction form. We also thank Sholom Glouberman, Jean Légaré, Carrie A. Levin, Karli Lopez, Victor Montori, and Kerri Sparling, who were invaluable members of the project team but who were not co-authors on this paper due to other commitments. Although they did not co-author this particular paper, their contributions helped shape this work. Finally, we thank all authors of the original articles who generously gave their time to validate the detailed data we had extracted from their publications. We sincerely appreciate their willingness to help us ensure we appropriately represented their studies. 


\section{Author Information}

The first through sixth and last (senior) author are listed according to their levels of contribution within this study. All other authors are listed alphabetically.

GV: Office of Education and Continuing Professional Development, Faculty of Medicine, Pavillon Ferdinand-Vandry 2881, Laval University, Quebec City, Quebec G1V 0A6, Canada TP: Office of Education and Continuing Professional Development, Faculty of Medicine, Pavillon Ferdinand-Vandry 2881, Laval University, Quebec City, Quebec G1V 0A6, Canada MD: Office of Education and Continuing Professional Development, Faculty of Medicine, Pavillon Ferdinand-Vandry 2881, Laval University, Quebec City, Quebec G1V 0A6, Canada MET: Office of Education and Continuing Professional Development, Faculty of Medicine, Pavillon Ferdinand-Vandry 2881, Laval University, Quebec City, Quebec G1V 0A6, Canada SCD: Office of Education and Continuing Professional Development, Faculty of Medicine, Pavillon Ferdinand-Vandry 2881, Laval University, Quebec City, Quebec G1V 0A6, Canada HC: Department of Occupational Science and Occupational Therapy, Faculty of Medicine, University of Toronto, 60-500 University Ave, Toronto, Ontario M5G 1V7, Canada AF: Department of Population Health Sciences, University of Utah, 295 Chipeta Way, Williams Building, Room 1C448 - Salt Lake City, Utah 84132, USA AMCG: Department of Family and Emergency Medicine, Office of Education and Continuing Professional Development, Faculty of Medicine, Pavillon Ferdinand-Vandry 2881, Laval University, Quebec City, Quebec G1V 0A6, Canada Office of Education and Continuing Professional Development, Faculty of Medicine, Pavillon Ferdinand-Vandry 2881, Laval University, Quebec City, Quebec G1V 0A6, Canada Quebec Centre for Excellence in Aging, Research Centre of the CHU de Quebec, St Sacrement Hospital, Local L2-08, 1050 chemin Sainte Foy, Quebec City, Quebec G1S 4L8, Canada $\mathrm{HH}$ : Office of Education and Continuing Professional Development, Faculty of Medicine, Pavillon Ferdinand-Vandry 2881, Laval University, Quebec City, Quebec G1V 0A6, Canada LH: East End Community Health Centre, 1619 Queen St. E, Toronto, Ontario, M4L1G4, Canada ASH: Department of Health Services Research, The University of Texas MD Anderson Cancer Center, 1400 Pressler Street, Houston, Texas 77030, USA

NMI: Family Practice Health Centre and Institute for Health Systems Solutions and Virtual Care, Women's College Hospital, 77 Grenville Street 4th Floor, Toronto, Ontario M5S 1B3, Canada Department of Family and Community Medicine, University of Toronto, 500 University Avenue, 5th Floor, Toronto, Ontario M5G 1V7, Canada

ASJ: Research Centre of the CHU de Québec-Université Laval, 10, rue de l'Espinay, Quebec City, Quebec, G1L 3L5, Canada

FL: Department of Family and Emergency Medicine, Faculty of Medicine, Pavillon FerdinandVandry 4617, Laval University, Quebec City, Quebec G1V 0A6, Canada Research Centre of the Centre Hospitalier Universitaire de Québec, 10 rue de l'Espinay, Hôpital Saint François d'Assise D6- 727, Quebec City, Quebec G1L 3L5, Canada JL: Patient Partner, 403 rue des Érables, Neuville, Québec, G0A 2R0, Canada CAL: Informed Medical Decisions Foundation, a division of Healthwise, Inc., 40 Court St, Suite 300, Boston, Massachusetts 02108, USA 
JSR: Department of Family and Emergency Medicine, Office of Education and Continuing Professional Development, Faculty of Medicine, Pavillon Ferdinand-Vandry 2881, Laval University, Quebec City, Quebec G1V 0A6, Canada

Office of Education and Continuing Professional Development, Faculty of Medicine, Pavillon Ferdinand-Vandry 2881, Laval University, Quebec City, Quebec G1V 0A6, Canada DS: School of Nursing, University of Ottawa and Senior Scientist, Ottawa Hospital Research Institute, 451 Smyth Road (RGN 1118), Ottawa, Ontario, K1H 8M5, Canada RJV: Department of Health Services Research, The University of Texas MD Anderson Cancer Center, Houston, TX 77230, USA

HOW: Department of Family and Emergency Medicine, Office of Education and Continuing Professional Development, Faculty of Medicine, Pavillon Ferdinand-Vandry 2881, Laval University, Quebec City, Quebec G1V 0A6, Canada; Office of Education and Continuing Professional Development, Faculty of Medicine, Pavillon Ferdinand-Vandry 2881, Laval University, Quebec City, Quebec G1V 0A6, Canada; 


\section{References}

1. Barry MJ, Edgman-Levitan S. Shared decision making - the pinnacle of patient-centered care. N. Engl. J. Med. Mass Medical Soc; 2012;366:780-1.

2. Mulley AG, Trimble C, Elwyn G. Stop the silent misdiagnosis: patients' preferences matter. BMJ. 2012;345:e6572.

3. Stacey D, Légaré F, Lewis K, Barry MJ, Bennett CL, Eden KB, et al. Decision aids for people facing health treatment or screening decisions. John Wiley \& Sons, Ltd; 2017; Available from: http://dx.doi.org/10.1002/14651858.CD001431.pub5

4. Spatz ES, Krumholz HM, Moulton BW. Prime Time for Shared Decision Making. JAMA. 2017;317:1309-10.

5. Abras C, Maloney-Krichmar D, Preece J. User-centered design. Encyclopedia of HumanComputer Interaction. Thousand Oaks: Sage Publications; 2004;37:445-56.

6. Kelley T, Littman J. The Art of Innovation: Lessons in Creativity from IDEO, America's Leading Design Firm. 1st ed. Crown Business; 2001.

7. Norman DA. The Design of Everyday Things. Basic Books; 2002.

8. Shneiderman B, Plaisant C. Designing the User Interface: Strategies for Effective Humancomputer Interaction. 5th ed. Addison-Wesley; 2010.

9. ISO DIS. 9241-210: 2010. Ergonomics of human system interaction-Part 210: Human-centred design for interactive systems. International Standardization Organization (ISO). Switzerland.; 2009.

10. Searl MM, Borgi L, Chemali Z. It is time to talk about people: a human-centered healthcare system. Health Res. Policy Syst. 2010;8:35.

11. Wolpin S, Stewart M. A deliberate and rigorous approach to development of patientcentered technologies. Semin. Oncol. Nurs. 2011;27:183-91.

12. Elkin PL. Human Factors Engineering in HI: So What? Who Cares? and What's in It for You? Healthc. Inform. Res. 2012;18:237-41.

13. Gurses AP, Ozok AA, Pronovost PJ. Time to accelerate integration of human factors and ergonomics in patient safety. BMJ Qual. Saf. 2012;21:347-51.

14. Bauman KE, Ennett ST, Foshee VA, Pemberton M, King TS, Koch GG. Influence of a Family-Directed Program on Adolescent Cigarette and Alcohol Cessation. Prev. Sci. 2000;1:227-37.

15. McDaniel AM, Casper GR, Hutchison SK, Stratton RM. Design and testing of an interactive smoking cessation intervention for inner-city women. Health Educ. Res. 2005;20:379-84.

16. Nordfeldt S, Hanberger L, Malm F, Ludvigsson J. Development of a PC-based diabetes 
simulator in collaboration with teenagers with type 1 diabetes. Diabetes Technol. Ther. 2007;9:17-25.

17. Fonda SJ, Kedziora RJ, Vigersky RA, Bursell S-E. Evolution of a web-based, prototype Personal Health Application for diabetes self-management. J. Biomed. Inform. Elsevier Inc.; 2010;43:S17-21.

18. Fico G, Fioravanti A, Arredondo MT, Leuteritz J-P, Guillen A, Fernandez D. A user centered design approach for patient interfaces to a diabetes IT platform. Conf. Proc. IEEE Eng. Med. Biol. Soc. 2011;2011:1169-72.

19. Zickler C, Halder S, Kleih SC, Herbert C, Kübler A. Brain painting: Usability testing according to the user-centered design in end users with severe motor paralysis. Artif. Intell. Med. Elsevier B.V.; 2013;59:99-110.

20. Weightman APH, Preston N, Holt R, Allsop M, Levesley M, Bhakta B. Engaging children in healthcare technology design: developing rehabilitation technology for children with cerebral palsy. J. Eng. Des. 2010;21:579-600.

21. Witteman HO, Dansokho SC, Colquhoun H, Coulter A, Dugas M, Fagerlin A, et al. Usercentered design and the development of patient decision aids: protocol for a systematic review. Syst. Rev. 2015;4:11.

22. User-centered design of patient decision aids [Internet]. [cited 2017 Apr 21]. Available from: http://www.crd.york.ac.uk/PROSPERO/display_record.asp?ID=CRD42014013241

23. Stacey $D$, Légaré $F, N f C, C l B, M j B, K b E$, et al. Decision aids for people facing health treatment or screening decisions. Cochrane Database Syst. Rev. 2014;CD001431.

24. Witteman HO, Scherer LD, Gavaruzzi T, Pieterse AH, Fuhrel-Forbis A, Chipenda Dansokho $\mathrm{S}$, et al. Design Features of Explicit Values Clarification Methods: A Systematic Review. Med. Decis. Making. 2016;36:453-71.

25. Witteman HO, Gavaruzzi T, Scherer LD, Pieterse AH, Fuhrel-Forbis A, Chipenda Dansokho $\mathrm{S}$, et al. Effects of Design Features of Explicit Values Clarification Methods: A Systematic Review. Med. Decis. Making. 2016;36:760-76.

26. Moher D, Shamseer L, Clarke M, Ghersi D, Liberati A, Petticrew M, et al. Preferred reporting items for systematic review and meta-analysis protocols (PRISMA-P) 2015 statement. Syst. Rev. 2015;4:1.

27. Dugas M, Trottier M-Ė, Chipenda Dansokho S, Vaisson G, Provencher T, Colquhoun H, et al. Involving members of vulnerable populations in the development of patient decision aids: a mixed methods sequential explanatory study. BMC Med. Inform. Decis. Mak. BMC Medical Informatics and Decision Making; 2017;17:12.

28. Pluye P, Gagnon MP, Griffiths F, Johnson-Lafleur J. A scoring system for appraising mixed methods research, and concomitantly appraising qualitative, quantitative and mixed methods primary studies in Mixed Studies Reviews. Int. J. Nurs. Stud. 2009;46:529-46.

29. R Development Core Team. R: A language and environment for statistical computing 
[Internet]. Vienna, Austria: R Foundation for Statistical Computing; 2016. Available from: https://www.R-project.org/

30. Revelle W. Procedures for Psychological, Psychometric, and Personality Research [Internet]. 2017. Available from: https://cran.r-project.org/web/packages/psych/psych.pdf

31. Brett J, Staniszewska S, Mockford C, Herron-Marx S, Hughes J, Tysall C, et al. Mapping the impact of patient and public involvement on health and social care research: A systematic review. Health Expect. 2014;17:637-50.

32. Topic of conversation. Den Haag, Netherlands: Dutch organization for health and innovation in healthcare; 2010.

33. Collier R. Federal government unveils patient-oriented research strategy. Can. Med. Assoc. J. 2011;183:E993-4.

34. Coulter A, Kryworuchko J, Mullen PD, Ng C-K, Stilwell D, van der Weijden T. Chapter A: Using a systematic development process. Update of the International Patient Decision Aids Standards (IPDAS) Collaboration's Background Document. 2012;1-16.

35. Coulter A, Stilwell D, Kryworuchko J, Mullen P, $\mathrm{Ng} \mathrm{C}$, van der Weijden $\mathrm{T}$, et al. A systematic development process for patient decision aids. BMC Med. Inform. Decis. Mak. 2013;13:S2.

36. Elwyn G, Laitner S, Coulter A, Walker E, Watson P, Thomson R. Implementing shared decision making in the NHS. BMJ [Internet]. 2010;341. Available from:

http://www.bmj.com/content/341/bmj.c5146.abstract

37. Guadagnoli E, Ward P. Patient participation in decision-making. Social Science and Medicine. 1998;47:329-39.

38. Cofré JP, Moraga G, Rusu C, Mercado I, Inostroza R, Jiménez C. Developing a touchscreen-based domotic tool for users with motor disabilities. Proceedings of the 9th International Conference on Information Technology, ITNG 2012. 2012;696-701.

39. Hawley MS, Cunningham SP, Green PD, Enderby P, Palmer R, Sehgal S, et al. A voiceinput voice-output communication aid for people with severe speech impairment. IEEE Trans. Neural Syst. Rehabil. Eng. 2013;21:23-31.

40. Klack L, Möllering C, Ziefle M, Schmitz-Rode T. Future Care Floor: A Sensitive Floor for Movement Monitoring and Fall Detection in Home Environments. 2011;211-8.

41. Agre P, Kurtz RC, Krauss BJ. A randomized trial using videotape to present consent information for colonoscopy. Gastrointestinal endoscopy. 1994;40:271-6.

42. Akl EA, Grant BJB, Guyatt GH, Montori VM, Schünemann HJ. A decision aid for COPD patients considering inhaled steroid therapy: development and before and after pilot testing. BMC Med. Inform. Decis. Mak. 2007;7:12.

43. AlFaleh KM, Luwaimi EA, AlKharfi TM, Al-Alaiyan SA. A decision aid for considering indomethacin prophylaxis vs. symptomatic treatment of PDA for extreme low birth weight infants. BMC Pediatr. 2011;11:78. 
44. Allen JD, Mohllajee AP, Shelton RC, Drake BF, Mars DR. A computer-tailored intervention to promote informed decision making for prostate cancer screening among African American men. Am. J. Mens. Health. 2009;3:340-51.

45. Allen JD, Othus MKD, Hart A Jr, Tom L, Li Y, Berry D, et al. A randomized trial of a computer-tailored decision aid to improve prostate cancer screening decisions: results from the Take the Wheel trial. Cancer Epidemiol. Biomarkers Prev. 2010;19:2172-86.

46. Ameling JM, Auguste P, Ephraim PL, Lewis-Boyer L, DePasquale N, Greer RC, et al. Development of a decision aid to inform patients' and families' renal replacement therapy selection decisions. BMC Med. Inform. Decis. Mak. 2012;12:140.

47. Anderson C, Carter J, Nattress K, Beale P, Philp S, Harrison J, et al. "The booklet helped me not to panic": a pilot of a decision aid for asymptomatic women with ovarian cancer and with rising CA-125 levels. Int. J. Gynecol. Cancer. 2011;21:737-43.

48. Aneja S, Brimhall AK, Aneja S, Kast DR, Carlson D, Cooper KD, et al. Computerized interactive educational tools used to improve use of sun-protective clothing and sunscreen: a randomized controlled study. Archives of dermatology. 2012;148:1325-7.

49. Aoki N, Sakai M, Nakayama T, Fukuhara S, Ohta S, Kikuchi N, et al. u-SHARE: web-based decision support/risk communication tool for healthcare consumers with unruptured intracranial aneurysms. Stud. Health Technol. Inform. 2007;129:1012-6.

50. Arimori N. Randomized controlled trial of decision aids for women considering prenatal testing: The effect of the Ottawa Personal Decision Guide on decisional conflict. Jpn. J. Nurs. Sci. Blackwell Publishing Asia; 2006;3:119-30.

51. Arterburn DE, Westbrook EO, Bogart TA, Sepucha KR, Bock SN, Weppner WG. Randomized Trial of a Video-Based Patient Decision Aid for Bariatric Surgery. Obesity . 2011;19:1669-75.

52. Au AHY, Lam WWT, Chan MCM, Or AYM, Kwong A, Suen D, et al. Development and pilottesting of a Decision Aid for use among Chinese women facing breast cancer surgery. Health Expect. 2011;14:405-16.

53. Lam WWT, Chan M, Or A, Kwong A, Suen D, Fielding R. Reducing treatment decision conflict difficulties in breast cancer surgery: a randomized controlled trial. J. Clin. Oncol. 2013;31:2879-85.

54. Auvinen A, Hakama M, Ala-Opas M, Vornanen T, Leppilahti M, Salminen P, et al. A randomized trial of choice of treatment in prostate cancer: the effect of intervention on the treatment chosen. BJU Int. 2004;93:52-6.

55. Baena Cañada JM, Ramírez Daffós P, Díaz Díaz V, Estalella Mendoza S, Díaz Gómez L, González Calvo E, et al. [Experience with a simplified format of decision making tool adjuvant! Online in breast cancer patients]. Rev. Calid. Asist. 2010;25:228-31.

56. Bailey DB Jr, Lewis MA, Harris SL, Grant T, Bann C, Bishop E, et al. Design and evaluation of a decision aid for inviting parents to participate in a fragile $X$ newborn screening pilot study. $J$. Genet. Couns. 2013;22:108-17. 
57. Bailey DB Jr, Bann C, Bishop E, Guarda S, Barnum L, Roche M. Can a decision aid enable informed decisions in neonatal nursery recruitment for a fragile $X$ newborn screening study? Genet. Med. 2013;15:299-306.

58. Barnieh L, McLaughlin K, Manns BJ, Klarenbach S, Yilmaz S, Taub K, et al. Evaluation of an education intervention to increase the pursuit of living kidney donation: a randomized controlled trial. Prog. Transplant. 2011;21:36-42.

59. Barry MJ, Fowler FJ Jr, Mulley AG Jr, Henderson JV Jr, Wennberg JE. Patient reactions to a program designed to facilitate patient participation in treatment decisions for benign prostatic hyperplasia. Med. Care. journals.Iww.com; 1995;33:771-82.

60. Barry MJ, Cherkin DC, Chang Y, Fowler FJ Jr, Skates S. A Randomized Trial of a Multimedia Shared Decision-Making Program for Men Facing a Treatment Decision for Benign Prostatic Hyperplasia. Disease Management and Clinical Outcomes. 1997;1:5-14.

61. Piercy GB, Deber R, Trachtenberg J, Ramsey EW, Norman RW, Goldenberg SL, et al. Impact of a shared decision-making program on patients with benign prostatic hyperplasia. Urology. 1999;53:913-20.

62. Rovner DR, Wills CE, Bonham V, Williams G, Lillie J, Kelly-Blake K, et al. Decision aids for benign prostatic hyperplasia: applicability across race and education. Med. Decis. Making. 2004;24:359-66.

63. Holmes-Rovner M, Price C, Rovner DR, Kelly-Blake K, Lillie J, Wills C, et al. Men's theories about benign prostatic hyperplasia and prostate cancer following a benign prostatic hyperplasia decision aid. J. Gen. Intern. Med. Wiley Online Library; 2006;21:56-60.

64. Wills CE, Holmes-Rovner M, Rovner D, Lillie J, Kelly-Blake K, Bonham V, et al. Treatment preference patterns during a videotape decision aid for benign prostatic hyperplasia (BPH). Patient Educ. Couns. 2006;61:16-22.

65. Pylar J, Wills CE, Lillie J, Rovner DR, Kelly-Blake K, Holmes-Rovner M. Men's interpretations of graphical information in a videotape decision aid. Health Expect. Blackwell Publishing Ltd; 2007;10:184-93.

66. Bass SB, Gordon TF, Ruzek SB, Wolak C, Ruggieri D, Mora G, et al. Developing a computer touch-screen interactive colorectal screening decision aid for a low-literacy African American population: lessons learned. Health Promot. Pract. 2013;14:589-98.

67. Bastian LA, McBride CM, Fish L, Lyna P, Farrell D, Lipkus IM, et al. Evaluating participants' use of a hormone replacement therapy decision-making intervention. Patient Educ. Couns. 2002;48:283-91.

68. McBride CM, Bastian LA, Halabi S, Fish L, Lipkus IM, Bosworth HB, et al. A tailored intervention to aid decisionmaking about hormone replacement therapy. American journal of public health. 2002;92:1112-4.

69. Beach LR, Townes BD, Campbell FL, Keating GW. Developing and testing a decision aid for birth planning decisions. Organ. Behav. Hum. Perform. 1976;15:99-116. 
70. Beamond BM, Beischer AD, Brodsky JW, Leslie H. Improvement in surgical consent with a preoperative multimedia patient education tool: a pilot study. Foot Ankle Int. 2009;30:619-26.

71. Becker H, Stuifbergen AK, Dormire SL. The effects of hormone therapy decision support for women with mobility impairments. Health Care Women Int. 2009;30:845-54.

72. Bekker H, Thornton JG, Airey CM, Connelly JB, Hewison J, Robinson MB, et al. Informed decision making: an annotated bibliography and systematic review. Health Technol. Assess. 1999;3:1-156.

73. Bekker HL, Hewison J, Thornton JG. Applying decision analysis to facilitate informed decision making about prenatal diagnosis for Down syndrome: a randomised controlled trial. Prenat. Diagn. 2004;24:265-75.

74. Berman L, Curry L, Goldberg C, Gusberg R, Fraenkel L. Pilot testing of a decision support tool for patients with abdominal aortic aneurysms. J. Vasc. Surg. 2011;53:285-92.e1.

75. Bernstein SJ, Skarupski KA, Grayson CE, Starling MR, Bates ER, Eagle KA. A randomized controlled trial of information-giving to patients referred for coronary angiography: effects on outcomes of care. Health Expect. 1998;1:50-61.

76. Berry DL, Halpenny B, Wolpin S, Davison BJ, Ellis WJ, Lober WB, et al. Development and evaluation of the personal patient profile-prostate (P3P), a Web-based decision support system for men newly diagnosed with localized prostate cancer. J. Med. Internet Res. JMIR Publications Inc.; 2010;12:e67.

77. Berry DL, Halpenny B, Hong F, Wolpin S, Lober WB, Russell KJ, et al. The Personal Patient Profile-Prostate decision support for men with localized prostate cancer: a multi-center randomized trial. Urol. Oncol. 2013;31:1012-21.

78. Bieber C, Müller KG, Blumenstiel K, Schuller-Roma B, Richter A, Hochlehnert A, et al. Partizipative Entscheidungsfindung (PEF) mit chronischen Schmerzpatienten.

Bundesgesundheitsbl - Gesundheitsforsch- Gesundheitsschutz. Springer-Verlag; 2004;47:98591.

79. Björklund U, Marsk A, Levin C, Öhman SG. Audiovisual information affects informed choice and experience of information in antenatal Down syndrome screening - A randomized controlled trial. Patient Educ. Couns. Elsevier; 2012;86:390-5.

80. Öhman SG, Björklund U, Marsk A. Does an informational film increase women's possibility to make an informed choice about second trimester ultrasound? Prenat. Diagn. John Wiley \& Sons, Ltd; 2012;32:833-9.

81. Breslin M, Mullan RJ, Montori VM. The design of a decision aid about diabetes medications for use during the consultation with patients with type 2 diabetes. Patient Educ. Couns. 2008;73:465-72.

82. Mullan RJ, Montori VM, Shah ND, Christianson TJH, Bryant SC, Guyatt GH, et al. The diabetes mellitus medication choice decision aid: a randomized trial. Arch. Intern. Med. 2009;169:1560-8. 
83. Brink SG, Birney AJ, McFarren AE. Charting Your Course: Formative Evaluation of a Prostate Cancer Treatment Decision Aid. Int Electron J Health Educ. 2000;3:44-54.

84. Fagerlin A, Rovner D, Stableford S, Jentoft C, Wei JT, Holmes-Rovner M. Patient education materials about the treatment of early-stage prostate cancer: a critical review. Ann. Intern. Med. Am Coll Physicians; 2004;140:721-8.

85. Taylor KL, Davis KM, Lamond T, Williams RM, Schwartz MD, Lawrence W, et al. Use and evaluation of a CD-ROM-based decision aid for prostate cancer treatment decisions. Behav. Med. 2010;36:130-40.

86. Brohan E, Henderson C, Slade M, Thornicroft G. Development and preliminary evaluation of a decision aid for disclosure of mental illness to employers. Patient Educ. Couns. 2014;94:23842.

87. Brohan E, Evans-Lacko S, Henderson C, Murray J, Slade M, Thornicroft G. Disclosure of a mental health problem in the employment context: qualitative study of beliefs and experiences. Epidemiol. Psychiatr. Sci. Cambridge University Press; 2014;23:289-300.

88. Brundage MD, Feldman-Stewart D, Dixon P, Gregg R, Youssef Y, Davies D, et al. A treatment trade-off based decision aid for patients with locally advanced non-small cell lung cancer. Health Expect. 2000;3:55-68.

89. Brundage MD, Feldman-Stewart D, Cosby R, Gregg R, Dixon P, Youssef Y, et al. Phase I Study of a Decision Aid for Patients With Locally Advanced Non-Small-Cell Lung Cancer. J. Clin. Oncol. 2001;19:1326-35.

90. Brunette MF, Ferron JC, McHugo GJ, Davis KE, Devitt TS, Wilkness SM, et al. An Electronic Decision Support System to Motivate People With Severe Mental Illnesses to Quit Smoking. Psychiatr. Serv. 2011;62:360-6.

91. Caldon LJM, Collins KA, Reed MW, Sivell S, Austoker J, Clements AM, et al. Clinicians' concerns about decision support interventions for patients facing breast cancer surgery options: understanding the challenge of implementing shared decision-making. Health Expect. Blackwell Publishing Ltd; 2011;14:133-46.

92. Jones B. BresDex: helping women make breast cancer surgery choices. J. Vis. Commun. Med. 2012;35:59-64.

93. Sivell S, Marsh W, Edwards A, Manstead ASR, Clements A, Elwyn G, et al. Theory-based design and field-testing of an intervention to support women choosing surgery for breast cancer: BresDex. Patient Educ. Couns. 2012;86:179-88.

94. Sivell S, Edwards A, Manstead ASR, Reed MWR, Caldon L, Collins K, et al. Increasing readiness to decide and strengthening behavioral intentions: evaluating the impact of a webbased patient decision aid for breast cancer treatment options (BresDex: www.bresdex.com). Patient Educ. Couns. 2012;88:209-17.

95. Carrère M-O, Moumjid-Ferdjaoui N, Charavel M, Brémond A. Eliciting patients' preferences for adjuvant chemotherapy in breast cancer: development and validation of a bedside decisionmaking instrument in a French Regional Cancer Centre. Health Expectations. 2000;3:97-113. 
96. Chewning B, Mosena P, Wilson D, Erdman H, Potthoff S, Murphy A, et al. Evaluation of a computerized contraceptive decision aid for adolescent patients. Patient Educ. Couns.

1999;38:227-39.

97. Chiew KS, Shepherd H, Vardy J, Tattersall MHN, Butow PN, Leighl NB. Development and evaluation of a decision aid for patients considering first-line chemotherapy for metastatic breast cancer. Health Expect. 2008;11:35-45.

98. Chiou C-P, Chung Y-C. Effectiveness of multimedia interactive patient education on knowledge, uncertainty and decision-making in patients with end-stage renal disease. J. Clin. Nurs. 2012;21:1223-31.

99. Clancy CM, Cebul RD, Williams SV. Guiding individual decisions: a randomized, controlled trial of decision analysis. Am. J. Med. 1988;84:283-8.

100. Consoli SM, Ben Said M, Jean J, Menard J, Plouin PF, Chatellier G. Benefits of a computer-assisted education program for hypertensive patients compared with standard education tools. Patient Educ. Couns. 1995;26:343-7.

101. Costanza ME, Luckmann RS, Rosal M, White MJ, LaPelle N, Partin M, et al. Helping men make an informed decision about prostate cancer screening: a pilot study of telephone counseling. Patient Educ. Couns. 2011;82:193-200.

102. Cox CE, Lewis CL, Hanson LC, Hough CL, Kahn JM, White DB, et al. Development and pilot testing of a decision aid for surrogates of patients with prolonged mechanical ventilation. Crit. Care Med. 2012;40:2327-34.

103. Coylewright M, Shepel K, Leblanc A, Pencille L, Hess E, Shah N, et al. Shared decision making in patients with stable coronary artery disease: PCI choice. PLoS One. 2012;7:e49827.

104. Cranney A, O'Connor AM, Jacobsen MJ, Tugwell P, Adachi JD, Ooi DS, et al. Development and pilot testing of a decision aid for postmenopausal women with osteoporosis. Patient Educ. Couns. 2002;47:245-55.

105. Culver JO, MacDonald DJ, Thornton AA, Sand SR, Grant M, Bowen DJ, et al. Development and evaluation of a decision aid for BRCA carriers with breast cancer. J. Genet. Couns. 2011;20:294-307.

106. Cupertino AP, Richter K, Cox LS, Garrett S, Ramirez R, Mujica F, et al. Feasibility of a Spanish/English computerized decision aid to facilitate smoking cessation efforts in underserved communities. J. Health Care Poor Underserved. 2010;21:504-17.

107. Dales RE, O'Connor A, Hebert P, Sullivan K, McKim D, Llewellyn-Thomas H. Intubation and mechanical ventilation for COPD: development of an instrument to elicit patient preferences. Chest. 1999;116:792-800.

108. Wilson KG, Aaron SD, Vandemheen KL, Hébert PC, McKim DA, Fiset V, et al. Evaluation of a decision aid for making choices about intubation and mechanical ventilation in chronic obstructive pulmonary disease. Patient Educ. Couns. 2005;57:88-95.

109. D'Alimonte L, Angus J, Wong J, Paszat L, Soren B, Szumacher E. Working Toward a 
Decision: The Development and First Impressions of a Decision Aid for Older Women with Early-stage Breast Cancer. Journal of Medical Imaging and Radiation Sciences. Elsevier; 2012;43:60-5.

110. Davis TC, Fredrickson DD, Arnold C, Murphy PW, Herbst M, Bocchini JA. A polio immunization pamphlet with increased appeal and simplified language does not improve comprehension to an acceptable level. Patient Educ. Couns. 1998;33:25-37.

111. Deschamps MA, Taylor JG, Neubauer SL, Whiting S, Green K. Impact of pharmacist consultation versus a decision aid on decision making regarding hormone replacement therapy. Int. J. Pharm. Pract. Blackwell Publishing Ltd; 2004;12:21-8.

112. Dillard AJ, Fagerlin A, Dal Cin S, Zikmund-Fisher BJ, Ubel PA. Narratives that address affective forecasting errors reduce perceived barriers to colorectal cancer screening. Soc. Sci. Med. 2010;71:45-52.

113. Dobs AS, Masters RB, Rajaram L, Stillman FA, Wilder LB, Margolis S, et al. A comparison of education methods and their impact on behavioral change in patients with hyperlipidemia. Patient Educ. Couns. 1994;24:157-64.

114. Dodin S, Légaré F, Daudelin G, Tetroe J, O'Connor A. Prise de décision en matière d'hormonothérapie de remplacement. Essai clinique randomisé. Can. Fam. Physician. 2001;47:1586-93.

115. Dolan JG, Frisina S. Randomized controlled trial of a patient decision aid for colorectal cancer screening. Med. Decis. Making. 2002;22:125-39.

116. Dolan JG, Veazie PJ, Russ AJ. Development and initial evaluation of a treatment decision dashboard. BMC Med. Inform. Decis. Mak. 2013;13:51.

117. Dowding D, Swanson V, Bland R, Thomson P, Mair C, Morrison A, et al. The development and preliminary evaluation of a decision aid based on decision analysis for two treatment conditions: benign prostatic hyperplasia and hypertension. Patient Educ. Couns. 2004;52:209_ 15.

118. Thomson P, Dowding D, Swanson V, Bland R, Mair C, Morrison A, et al. A computerised guidance tree (decision aid) for hypertension, based on decision analysis: development and preliminary evaluation. Eur. J. Cardiovasc. Nurs. 2006;5:146-9.

119. Drake ER, Engler-Todd L, O'Connor AM, Surh LC, Hunter A. Development and Evaluation of a Decision Aid About Prenatal Testing for Women of Advanced Maternal Age. J. Genet. Couns. 1999;8:217-33.

120. Hunter AGW, Cappelli M, Humphreys L, Allanson JE, Chiu TT, Peeters C, et al. A randomized trial comparing alternative approaches to prenatal diagnosis counseling in advanced maternal age patients. Clin. Genet. 2005;67:303-13.

121. Drake BF, Shelton RC, Gilligan T, Allen JD. A church-based intervention to promote informed decision making for prostate cancer screening among African American men. J. Natl. Med. Assoc. 2010;102:164-71. 
122. Du W, Mood D, Gadgeel S, Simon MS. An educational video to increase clinical trials enrollment among lung cancer patients. J. Thorac. Oncol. 2008;3:23-9.

123. Dunn RA, Shenouda PE, Martin DR, Schultz AJ. Videotape increases parent knowledge about poliovirus vaccines and choices of polio vaccination schedules. Pediatrics. 1998;102:e26.

124. Durand MA. Amniocentesis dilemma: Needs assessment, development and field-testing of a theory-based decision support intervention. Cardiff University, United Kingdom; 2009.

125. Durand M-A, Stiel M, Boivin J, Elwyn G. Information and decision support needs of parents considering amniocentesis: interviews with pregnant women and health professionals. Health Expect. 2010;13:125-38.

126. Durand M-A, Wegwarth O, Boivin J, Elwyn G. Design and usability of heuristic-based deliberation tools for women facing amniocentesis. Health Expect. 2012;15:32-48.

127. Eden KB, Dolan JG, Perrin NA, Kocaoglu D, Anderson N, Case J, et al. Patients were more consistent in randomized trial at prioritizing childbirth preferences using graphic-numeric than verbal formats. J. Clin. Epidemiol. 2009;62:415-24.e3.

128. Eden KB, Perrin NA, Vesco KK, Guise J-M. A randomized comparative trial of two decision tools for pregnant women with prior cesareans. J. Obstet. Gynecol. Neonatal Nurs.

2014;43:568-79.

129. Elit LM, Levine MN, Gafni A, Whelan TJ, Doig G, Streiner DL, et al. Patients' preferences for therapy in advanced epithelial ovarian cancer: development, testing, and application of a bedside decision instrument. Gynecol. Oncol. 1996;62:329-35.

130. El-Jawahri A, Podgurski LM, Eichler AF, Plotkin SR, Temel JS, Mitchell SL, et al. Use of video to facilitate end-of-life discussions with patients with cancer: a randomized controlled trial. J. Clin. Oncol. 2010;28:305-10.

131. Volandes AE, Levin TT, Slovin S, Carvajal RD, O'Reilly EM, Keohan ML, et al. Augmenting advance care planning in poor prognosis cancer with a video decision aid. Cancer. Wiley Subscription Services, Inc., A Wiley Company; 2012;118:4331-8.

132. Volandes AE, Paasche-Orlow MK, Mitchell SL, El-Jawahri A, Davis AD, Barry MJ, et al. Randomized controlled trial of a video decision support tool for cardiopulmonary resuscitation decision making in advanced cancer. J. Clin. Oncol. 2013;31:380-6.

133. Emmett CL, Murphy DJ, Patel RR, Fahey T, Jones C, Ricketts IW, et al. Decision-making about mode of delivery after previous caesarean section: development and piloting of two computer-based decision aids. Health Expect. 2007;10:161-72.

134. Montgomery AA, Emmett CL, Fahey T, Jones C, Ricketts I, Patel RR, et al. Two decision aids for mode of delivery among women with previous caesarean section: randomised controlled trial. British medical journal. 2007;334:1305-9.

135. Frost J, Shaw A, Montgomery A, Murphy DJ. Women's views on the use of decision aids for decision making about the method of delivery following a previous caesarean section: qualitative interview study. BJOG. 2009;116:896-905. 
136. Hollinghurst S, Emmett C, Peters TJ, Watson H, Fahey T, Murphy DJ, et al. Economic evaluation of the DiAMOND randomized trial: cost and outcomes of 2 decision aids for mode of delivery among women with a previous cesarean section. Med. Decis. Making. 2010;30:453-63.

137. Evans R, Elwyn G, Edwards A, Watson E, Austoker J, Grol R. Toward a model for fieldtesting patient decision-support technologies: a qualitative field-testing study. J. Med. Internet Res. 2007;9:e21.

138. Evans R, Joseph-Williams N, Edwards A, Newcombe RG, Wright P, Kinnersley P, et al. Supporting informed decision making for prostate specific antigen (PSA) testing on the web: an online randomized controlled trial. J. Med. Internet Res. 2010;12:e27.

139. Joseph-Williams N, Evans R, Edwards A, Newcombe RG, Wright P, Grol R, et al. Supporting Informed Decision Making Online in 20 Minutes: An Observational Web-log Study of a PSA Test Decision Aid. J. Med. Internet Res. Journal of Medical Internet Research; 2010;12:e15.

140. Fagerlin A, Zikmund-Fisher BJ, Nair V, Derry HA, McClure JB, Greene S, et al. Women's decisions regarding tamoxifen for breast cancer prevention: responses to a tailored decision aid. Breast Cancer Res. Treat. 2010;119:613-20.

141. Fagerlin A, Dillard AJ, Smith DM, Zikmund-Fisher BJ, Pitsch R, McClure JB, et al. Women's interest in taking tamoxifen and raloxifene for breast cancer prevention: response to a tailored decision aid. Breast Cancer Res. Treat. 2011;127:681-8.

142. Banegas MP, McClure JB, Barlow WE, Ubel PA, Smith DM, Zikmund-Fisher BJ, et al. Results from a randomized trial of a web-based, tailored decision aid for women at high risk for breast cancer. Patient Educ. Couns. 2013;91:364-71.

143. Korfage IJ, Fuhrel-Forbis A, Ubel PA, Zikmund-Fisher BJ, Greene SM, McClure JB, et al. Informed choice about breast cancer prevention: randomized controlled trial of an online decision aid intervention. Breast Cancer Res. 2013;15:R74.

144. Farnworth A, Robson SC, Thomson RG, Watson DB, Murtagh MJ. Decision support for women choosing mode of delivery after a previous caesarean section: a developmental study. Patient Educ. Couns. 2008;71:116-24.

145. Feldman-Stewart D, Brundage MD, Hayter C, Groome P, Curtis Nickel J, Downes H, et al. What questions do patients with curable prostate cancer want answered? Med. Decis. Making. 2000;20:7-19.

146. Feldman-Stewart D, Brundage MD, Nickel JC, MacKillop WJ. The information required by patients with early-stage prostate cancer in choosing their treatment. BJU Int. 2001;87:218-23.

147. Feldman-Stewart D, Brundage MD, Van Manen L. A decision aid for men with early stage prostate cancer: theoretical basis and a test by surrogate patients. Health Expect. 2001;4:22134.

148. Feldman-Stewart D, Brundage MD, Van Manen L, Skarsgard D, Siemens R. Evaluation of a question-and-answer booklet on early-stage prostate-cancer. Patient Educ. Couns.

2003;49:115-24. 
149. Feldman-Stewart D, Brundage MD, Van Manen L, Svenson O. Patient-focussed decisionmaking in early-stage prostate cancer: insights from a cognitively based decision aid. Health Expect. 2004;7:126-41.

150. Feldman-Stewart D, Brennenstuhl S, Brundage MD, Roques T. An explicit values clarification task: development and validation. Patient Educ. Couns. 2006;63:350-6.

151. Feldman-Stewart D, Brundage MD, Siemens R, Skarsgard D. A randomized controlled trial comparing two educational booklets on prostate cancer. Can. J. Urol. 2006;13:3321-6.

152. Feldman-Stewart D, Tong C, Siemens R, Alibhai S, Pickles T, Robinson J, et al. The impact of explicit values clarification exercises in a patient decision aid emerges after the decision is actually made: evidence from a randomized controlled trial. Med. Decis. Making. 2012;32:616-26.

153. Ruffin MT 4th, Fetters MD, Jimbo M. Preference-based electronic decision aid to promote colorectal cancer screening: results of a randomized controlled trial. Prev. Med. 2007;45:26773.

154. Fiks AG, Grundmeier RW, Mayne S, Song L, Feemster K, Karavite D, et al. Effectiveness of decision support for families, clinicians, or both on HPV vaccine receipt. Pediatrics. 2013;131:1114-24.

155. Fiset V, O'Connor AM, Evans W, Graham I, DeGrasse C, Logan J. Development and evaluation of a decision aid for patients with stage IV non-small cell lung cancer. Health Expectations. 2000;3:125-36.

156. Fleisher L, Buzaglo J, Collins M, Millard J, Miller SM, Egleston BL, et al. Using Health Communication Best Practices to Develop a Web- Based Provider-Patient Communication Aid: The CONNECT ${ }^{\mathrm{TM}}$ Study. Patient Educ. Couns. 2008;71:378-87.

157. Meropol NJ, Egleston BL, Buzaglo JS, Balshem A, Benson AB, Cegala DJ, et al. A Webbased communication aid for patients with cancer. Cancer. 2013;119:1437-45.

158. Flood AB, Wennberg JE, Nease RF, Fowler FJ, Ding J, Hynes LM, et al. The importance of patient preference in the decision to screen for prostate cancer. J. Gen. Intern. Med.

1996;11:342-9.

159. Partin MR, Nelson D, Radosevich D, Nugent S, Flood AB, Dillon N, et al. Randomized trial examining the effect of two prostate cancer screening educational interventions on patient knowledge, preferences, and behaviors. J. Gen. Intern. Med. 2004;19:835-42.

160. Partin MR, Nelson D, Flood AB, Friedemann-Sánchez G, Wilt TJ. Who uses decision aids? Subgroup analyses from a randomized controlled effectiveness trial of two prostate cancer screening decision support interventions. Health Expect. 2006;9:285-95.

161. Fortin JM, Hirota LK, Bond BE, O'Connor AM, Col NF. Identifying patient preferences for communicating risk estimates: a descriptive pilot study. BMC Med. Inform. Decis. Mak. 2001;1:2.

162. Bond B, Hirota L, Fortin J, Col N. Women like me: reflections on health and hormones from 
women treated for breast cancer. J. Psychosoc. Oncol. Taylor \& Francis; 2002;20:39-56.

163. Col NF, Ngo L, Fortin JM, Goldberg RJ, O'Connor AM. Can computerized decision support help patients make complex treatment decisions? A randomized controlled trial of an individualized menopause decision aid. Med. Decis. Making. 2007;27:585-98.

164. Fraenkel L, Rabidou N, Wittink D, Fried T. Improving informed decision-making for patients with knee pain. J. Rheumatol. 2007;34:1894-8.

165. de Achaval S, Fraenkel L, Volk RJ, Cox V, Suarez-Almazor ME. Impact of educational and patient decision aids on decisional conflict associated with total knee arthroplasty. Arthritis Care Res. 2012;64:229-37.

166. Fraenkel L, Street RL Jr, Fried TR. Development of a tool to improve the quality of decision making in atrial fibrillation. BMC Med. Inform. Decis. Mak. 2011;11:59.

167. Fraenkel L, Street RL Jr, Towle V, O'Leary JR, lannone L, Van Ness PH, et al. A pilot randomized controlled trial of a decision support tool to improve the quality of communication and decision-making in individuals with atrial fibrillation. J. Am. Geriatr. Soc. 2012;60:1434-41.

168. Fraenkel L, Peters E, Charpentier P, Olsen B, Errante L, Schoen RT, et al. Decision tool to improve the quality of care in rheumatoid arthritis. Arthritis Care Res. 2012;64:977-85.

169. Fraenkel L, Matzko CK, Webb DE, Oppermann B, Charpentier P, Peters E, et al. Use of Decision Support for Improved Knowledge, Values Clarification, and Informed Choice in Patients With Rheumatoid Arthritis. Arthritis Care Res. 2015;67:1496-502.

170. Frank C, Pichora D, Suurdt J, Heyland D. Development and use of a decision aid for communication with hospitalized patients about cardiopulmonary resuscitation preference. Patient Educ. Couns. 2010;79:130-3.

171. French RS, Cowan FM, Wellings K, Dowie J. The development of a multi-criteria decision analysis aid to help with contraceptive choices: My Contraception Tool. J. Fam. Plann. Reprod. Health Care. 2014;40:96-101.

172. Frosch DL, Kaplan RM, Felitti V. The evaluation of two methods to facilitate shared decision making for men considering the prostate-specific antigen test. J. Gen. Intern. Med. 2001;16:391-8.

173. Frosch DL, Kaplan RM, Felitti VJ. A randomized controlled trial comparing internet and video to facilitate patient education for men considering the prostate specific antigen test. J. Gen. Intern. Med. 2003;18:781-7.

174. Frosch DL, Légaré F, Mangione CM. Using decision aids in community-based primary care: a theory-driven evaluation with ethnically diverse patients. Patient Educ. Couns. 2008;73:490-6.

175. Frosch DL, Bhatnagar V, Tally S, Hamori CJ, Kaplan RM. Internet patient decision support: a randomized controlled trial comparing alternative approaches for men considering prostate cancer screening. Arch. Intern. Med. 2008;168:363-9. 
176. Bhatnagar V, Frosch DL, Tally SR, Hamori CJ, Lenert L, Kaplan RM. Evaluation of an internet-based disease trajectory decision tool for prostate cancer screening. Value Health. 2009;12:101-8.

177. Furber L, Murtagh GM, Bonas SA, Bankart JG, Thomas AL. Improving consultations in oncology: the development of a novel consultation aid. Br. J. Cancer. 2014;110:1101-9.

178. Gallo AM, Wilkie D, Suarez M, Labotka R, Molokie R, Thompson A, et al. Reproductive decisions in people with sickle cell disease or sickle cell trait. West. J. Nurs. Res.

2010;32:1073-90.

179. Wilkie DJ, Gallo AM, Yao Y, Molokie RE, Stahl C, Hershberger PE, et al. Reproductive health choices for young adults with sickle cell disease or trait: randomized controlled trial immediate posttest effects. Nurs. Res. 2013;62:352-61.

180. Gallo AM, Wilkie DJ, Wang E, Labotka RJ, Molokie RE, Stahl C, et al. Evaluation of the SCKnowIQ tool and reproductive CHOICES intervention among young adults with sickle cell disease or sickle cell trait. Clin. Nurs. Res. 2014;23:421-41.

181. Garvelink MM, ter Kuile MM, Fischer MJ, Louwé LA, Hilders CGJM, Kroep JR, et al. Development of a Decision Aid about fertility preservation for women with breast cancer in The Netherlands. J. Psychosom. Obstet. Gynaecol. 2013;34:170-8.

182. Gattellari M, Ward JE. Does evidence-based information about screening for prostate cancer enhance consumer decision-making? A randomised controlled trial. J. Med. Screen. 2003;10:27-39.

183. Gattellari M, Ward JE. A community-based randomised controlled trial of three different educational resources for men about prostate cancer screening. Patient Educ. Couns. 2005;57:168-82.

184. Gilbert P, Ciccarone D, Gansky SA, Bangsberg DR, Clanon K, McPhee SJ, et al. Interactive "Video Doctor" Counseling Reduces Drug and Sexual Risk Behaviors among HIVPositive Patients in Diverse Outpatient Settings. PLoS One. 2008;3:e1988.

185. Graham W, Wyatt J, Smith P, Kamal A, Fitzmaurice A, Smith N, et al. Randomised controlled trial comparing effectiveness of touch screen system with leaflet for providing women with information on prenatal tests. BMJ. British Medical Journal Publishing Group; 2000;320:155-60.

186. Grant FC, Laupacis A, O'Connor AM, Rubens F, Robblee J. Evaluation of a decision aid for patients considering autologous blood donation before open-heart surgery. CMAJ. 2001;164:1139-44.

187. Laupacis A, O'Connor AM, Drake ER, Rubens FD, Robblee JA, Grant FC, et al. A decision aid for autologous pre-donation in cardiac surgery - a randomized trial. Patient Educ. Couns. Elsevier; 2006;61:458-66.

188. Green MJ, Fost N. An interactive computer program for educating and counseling patients about genetic susceptibility to breast cancer. J. Cancer Educ. Taylor \& Francis; 1997;12:204-8. 
189. Lerman C, Biesecker B, Benkendorf JL, Kerner J, Gomez-Caminero A, Hughes C, et al. Controlled trial of pretest education approaches to enhance informed decision-making for BRCA1 gene testing. J. Natl. Cancer Inst. 1997;89:148-57.

190. Green MJ, Biesecker BB, Mclnerney AM, Mauger D, Fost N. An interactive computer program can effectively educate patients about genetic testing for breast cancer susceptibility. Am. J. Med. Genet. 2001;103:16-23.

191. Schwartz MD, Benkendorf J, Lerman C, Isaacs C, Ryan-Robertson A, Johnson L. Impact of educational print materials on knowledge, attitudes, and interest in BRCA1/BRCA2. Cancer. John Wiley \& Sons, Inc.; 2001;92:932-40.

192. Green MJ, Peterson SK, Baker MW, Harper GR, Friedman LC, Rubinstein WS, et al. Effect of a Computer-Based Decision Aid on Knowledge, Perceptions, and Intentions About Genetic Testing for Breast Cancer Susceptibility. JAMA. 2004;292:442-52.

193. Green MJ, Peterson SK, Baker MW, Friedman LC, Harper GR, Rubinstein WS, et al. Use of an educational computer program before genetic counseling for breast cancer susceptibility: Effects on duration and content of counseling sessions. Genet. Med. Nature Publishing Group; 2005;7:221-9.

194. Green MJ, Levi BH. Development of an interactive computer program for advance care planning. Health Expect. 2009;12:60-9.

195. Hossler C, Levi BH, Simmons Z, Green MJ. Advance care planning for patients with ALS: Feasibility of an interactive computer program. Amyotroph. Lateral Scler. 2011;12:172-7.

196. Markham SA, Levi BH, Green MJ, Schubart JR. Use of a Computer Program for Advance Care Planning with African American Participants. J. Natl. Med. Assoc. 2015;107:26-32.

197. Griffith JM, Sorenson JR, Jennings-Grant T, Fowler B. Development of an interactive computer-assisted instruction (ICAI) program for patient prenatal genetic screening and carrier testing for use in clinical settings. Patient Educ. Couns. 2005;59:199-204.

198. Guillén Ú, Suh S, Munson D, Posencheg M, Truitt E, Zupancic JAF, et al. Development and pretesting of a decision-aid to use when counseling parents facing imminent extreme premature delivery. J. Pediatr. 2012;160:382-7.

199. Gustafson D, Wise M, McTavish F, Taylor JO, Wolberg W, Stewart J, et al. Development and Pilot Evaluation of a Computer-Based Support System for Women with Breast Cancer. J. Psychosoc. Oncol. 1994;11:69-93.

200. Gustafson DH, Hawkins R, Pingree S, McTavish F, Arora NK, Mendenhall J, et al. Effect of computer support on younger women with breast cancer. J. Gen. Intern. Med. 2001;16:435-45.

201. Wise M, Han JY, Shaw B, McTavish F, Gustafson DH. Effects of using online narrative and didactic information on healthcare participation for breast cancer patients. Patient Educ. Couns. 2008;70:348-56.

202. Gustafson DH, Hawkins RP, Boberg EW, Bricker E, Pingree S, Chan CL. The use and impact of a computer-based support system for people living with AIDS and HIV infection. Proc. 
Annu. Symp. Comput. Appl. Med. Care. 1994;604-8.

203. Gustafson DH, Hawkins R, Boberg E, Pingree S, Serlin RE, Graziano F, et al. Impact of a patient-centered, computer-based health information/support system. Am. J. Prev. Med. 1999;16:1-9.

204. Hacking B, Wallace L, Scott S, Kosmala-Anderson J, Belkora J, McNeill A. Testing the feasibility, acceptability and effectiveness of a "decision navigation" intervention for early stage prostate cancer patients in Scotland - a randomised controlled trial. Psychooncology. 2013;22:1017-24.

205. Hacking B, Scott SE, Wallace LM, Shepherd SC, Belkora J. Navigating healthcare: a qualitative study exploring prostate cancer patients' and doctors' experience of consultations using a decision-support intervention. Psychooncology. 2014;23:665-71.

206. Hamann J, Langer B, Winkler V, Busch R, Cohen R, Leucht S, et al. Shared decision making for in-patients with schizophrenia. Acta Psychiatr. Scand. 2006;114:265-73.

207. Hamann J, Cohen R, Leucht S, Busch R, Kissling W. Shared decision making and longterm outcome in schizophrenia treatment. J. Clin. Psychiatry. 2007;68:992-7.

208. Hartling L, Scott SD, Johnson DW, Bishop T, Klassen TP. A randomized controlled trial of storytelling as a communication tool. PLoS One. 2013;8:e77800.

209. Harwood R, Douglas C, Clark D. Decision aids for breast and nodal surgery in patients with early breast cancer: development and a pilot study. Asia Pac. J. Clin. Oncol. Wiley Online Library; 2011;7:114-22.

210. Hawkins Virani AK, Creighton SM, Hayden MR. Developing a comprehensive, effective patient-friendly website to enhance decision making in predictive testing for Huntington disease. Genet. Med. 2013;15:466-72.

211. Heinrich E, de Nooijer J, Schaper NC, Schoonus-Spit MHG, Janssen MAJ, de Vries NK. Evaluation of the web-based Diabetes Interactive Education Programme (DIEP) for patients with type 2 diabetes. Patient Educ. Couns. Elsevier; 2012;86:172-8.

212. Heller L, Parker PA, Youssef A, Miller MJ. Interactive digital education aid in breast reconstruction. Plast. Reconstr. Surg. 2008;122:717-24.

213. Henderson VA, Barr KL, An LC, Guajardo C, Newhouse W, Mase R, et al. Communitybased participatory research and user-centered design in a diabetes medication information and decision tool. Prog. Community Health Partnersh. 2013;7:171-84.

214. Hewison J, Cuckle H, Baillie C, Sehmi I, Lindow S, Jackson F, et al. Use of videotapes for viewing at home to inform choice in Down syndrome screening: a randomised controlled trial. Prenat. Diagn. 2001;21:146-9.

215. Hightow-Weidman LB, Fowler B, Kibe J, McCoy R, Pike E, Calabria M, et al. HealthMpowerment.org: development of a theory-based HIVISTI website for young black MSM. AIDS Educ. Prev. 2011;23:1-12. 
216. Muessig KE, Pike EC, Fowler B, LeGrand S, Parsons JT, Bull SS, et al. Putting prevention in their pockets: developing mobile phone-based HIV interventions for black men who have sex with men. AIDS Patient Care STDS. 2013;27:211-22.

217. Muessig KE, Baltierra NB, Pike EC, Le Grand S, Hightow-Weidman LB. Achieving HIV risk reduction through HealthMpowerment. org, a user-driven eHealth intervention for young Black men who have sex with men and transgender women who have sex with men. Digital culture \& education. 2014;6:164.

218. Hightow-Weidman LB, Muessig KE, Pike EC, LeGrand S, Baltierra N, Rucker AJ, et al. HealthMpowerment.org: Building Community Through a Mobile-Optimized, Online Health Promotion Intervention. Health Educ. Behav. 2015;42:493-9.

219. Hill-Briggs F, Renosky R, Lazo M, Bone L, Hill M, Levine D, et al. Development and pilot evaluation of literacy-adapted diabetes and CVD education in urban, diabetic African Americans. J. Gen. Intern. Med. 2008;23:1491-4.

220. Schumann KP, Sutherland JA, Majid HM, Hill-Briggs F. Evidence-Based Behavioral Treatments for Diabetes: Problem-Solving Therapy. Diabetes Spectr. American Diabetes Association; 2011;24:64-9.

221. Majid HM, Schumann KP, Doswell A, Sutherland J, Hill Golden S, Stewart KJ, et al. Development and evaluation of the DECIDE to move! Physical activity educational video. Diabetes Educ. 2012;38:855-9.

222. Hochlehnert A, Richter A, Bludau H-B, Bieber C, Blumenstiel K, Mueller K, et al. A computer-based information-tool for chronic pain patients. Patient Educ. Couns. Elsevier; 2006;61:92-8.

223. Hoffner B, Bauer-Wu S, Hitchcock-Bryan S, Powell M, Wolanski A, Joffe S. "Entering a Clinical Trial: Is it Right for You?": a randomized study of The Clinical Trials Video and its impact on the informed consent process. Cancer. 2012;118:1877-83.

224. Holbrook A, Labiris R, Goldsmith $\mathrm{CH}$, Ota K, Harb S, Sebaldt RJ. Influence of decision aids on patient preferences for anticoagulant therapy: a randomized trial. CMAJ. 2007;176:1583-7.

225. Hollen PJ, Gralla RJ, Jones RA, Thomas CY, Brenin DR, Weiss GR, et al. A theory-based decision aid for patients with cancer: results of feasibility and acceptability testing of DecisionKEYS for cancer. Support. Care Cancer. 2013;21:889-99.

226. Hollen PJ, Tyc VL, Donnangelo SF, Shannon SV, O'Laughlen MC, Hinton I, et al. A substance use decision aid for medically at-risk adolescents: results of a randomized controlled trial for cancer-surviving adolescents. Cancer Nurs. 2013;36:355-67.

227. Holmes-Rovner M, Stableford S, Fagerlin A, Wei JT, Dunn RL, Ohene-Frempong J, et al. Evidence-based patient choice: a prostate cancer decision aid in plain language. BMC Med. Inform. Decis. Mak. 2005;5:16.

228. Hong C, Kim S, Curnew G, Schulman S, Pullenayegum E, Holbrook A. Validation of a patient decision aid for choosing between dabigatran and warfarin for atrial fibrillation. J. Popul. Ther. Clin. Pharmacol. 2013;20:e229-37. 
229. Hooker GW, Leventhal K-G, DeMarco T, Peshkin BN, Finch C, Wahl E, et al. Longitudinal changes in patient distress following interactive decision aid use among BRCA1/2 carriers: a randomized trial. Med. Decis. Making. 2011;31:412-21.

230. Hope N, Rombauts L. Can an educational DVD improve the acceptability of elective single embryo transfer? A randomized controlled study. Fertil. Steril. Elsevier; 2010;94:489-95.

231. Hutchison C, Campbell S. Evaluation of an information booklet for patients considering participation in phase I clinical trials in cancer. Eur. J. Cancer Care . 2002;11:131-8.

232. Huyghe E, Martinetti P, Sui D, Schover LR. Banking on Fatherhood: pilot studies of a computerized educational tool on sperm banking before cancer treatment. Psychooncology. 2009;18:1011-4.

233. Irwin E, Arnold A, Whelan TJ, Reyno LM, Cranton P. Offering a choice between two adjuvant chemotherapy regimens: a pilot study to develop a decision aid for women with breast cancer. Patient Educ. Couns. 1999;37:283-91.

234. Isebaert S, Van Audenhove C, Haustermans K, Junius S, Joniau S, De Ridder K, et al. Evaluating a decision aid for patients with localized prostate cancer in clinical practice. Urol. Int. 2008;81:383-8.

235. Izquierdo F, Gracia J, Guerra M, Blasco JA, Andradas E. Health technology assessmentbased development of a Spanish breast cancer patient decision aid. Int. J. Technol. Assess. Health Care. Cambridge University Press; 2011;27:363-8.

236. Jackson C, Cheater FM, Peacock R, Leask J, Trevena L. Evaluating a web-based MMR decision aid to support informed decision-making by UK parents: A before-and-after feasibility study. Health Educ. J. 2010;69:74-83.

237. Shourie S, Jackson C, Cheater FM, Bekker HL, Edlin R, Tubeuf S, et al. A cluster randomised controlled trial of a web based decision aid to support parents' decisions about their child's Measles Mumps and Rubella (MMR) vaccination. Vaccine. 2013;31:6003-10.

238. Tubeuf S, Edlin R, Shourie S, Cheater FM, Bekker H, Jackson C. Cost effectiveness of a web-based decision aid for parents deciding about MMR vaccination: a three-arm cluster randomised controlled trial in primary care. Br. J. Gen. Pract. 2014;64:e493-9.

239. Jefford M, Gibbs A, Reading D. Development and evaluation of an information booklet/decision-making guide for patients with colorectal cancer considering therapy in addition to surgery. Eur. J. Cancer Care . 2005;14:16-27.

240. Jenkins JP, Jones AR, Griffiths C. Explaining renal treatment to people with learning disabilities. Nursing times. 2007;104:28-9.

241. Jenkinson J, Wilson-Pauwels L, Jewett MA, Woolridge N. Development of a hypermedia program designed to assist patients with localized prostate cancer in making treatment decisions. J. Biocommun. 1998;25:2-11.

242. Jensen AB, Madsen B, Andersen P, Rose C. Information af kraeftpatienter for deltagelse $i$ kliniske forsog. Ugeskrift for Laeger. 1995;157:1016-20. 
243. Jibaja-Weiss ML, Volk RJ, Granch TS, Nefe NE, Spann SJ, Aoki N, et al. Entertainment education for informed breast cancer treatment decisions in low-literate women: development and initial evaluation of a patient decision aid. J. Cancer Educ. 2006;21:133-9.

244. Jibaja-Weiss ML, Volk RJ, Friedman LC, Granchi TS, Neff NE, Spann SJ, et al. Preliminary testing of a just-in-time, user-defined values clarification exercise to aid lower literate women in making informed breast cancer treatment decisions. Health Expect. 2006;9:218-31.

245. Jibaja-Weiss ML, Volk RJ, Granchi TS, Neff NE, Robinson EK, Spann SJ, et al. Entertainment education for breast cancer surgery decisions: A randomized trial among patients with low health literacy. Patient Educ. Couns. Elsevier; 2011;84:41-8.

246. Johnson BR, Schwartz A, Goldberg J, Koerber A. A chairside aid for shared decision making in dentistry: a randomized controlled trial. J. Dent. Educ. 2006;70:133-41.

247. Johnson SL, Kim YM, Church K. Towards client-centered counseling: development and testing of the WHO Decision-Making Tool. Patient Educ. Couns. 2010;81:355-61.

248. Langston AM, Rosario L, Westhoff CL. Structured contraceptive counseling-A randomized controlled trial. Patient Educ. Couns. Elsevier; 2010;81:362-7.

249. Juan AS, Wakefield CE, Kasparian NA, Kirk J, Tyler J, Tucker K. Development and Pilot Testing of a Decision Aid for Men Considering Genetic Testing for Breast and/or Ovarian Cancer-Related Mutations (BRCA1/2). Genetic testing. 2008;12:523-32.

250. Juraskova I, Butow P, Lopez A, Seccombe M, Coates A, Boyle F, et al. Improving informed consent: pilot of a decision aid for women invited to participate in a breast cancer prevention trial (IBIS-II DCIS). Health Expect. 2008;11:252-62.

251. Juraskova I, Butow P, Bonner C, Bell ML, Smith AB, Seccombe M, et al. Improving decision making about clinical trial participation - a randomised controlled trial of a decision aid for women considering participation in the IBIS-II breast cancer prevention trial. Br. J. Cancer. Nature Publishing Group; 2014;111:1-7.

252. Kasper J, Köpke S, Mühlhauser I, Nübling M, Heesen C. Informed shared decision making about immunotherapy for patients with multiple sclerosis (ISDIMS): a randomized controlled trial. Eur. J. Neurol. 2008;15:1345-52.

253. Köpke S, Kern S, Ziemssen T, Berghoff M, Kleiter I, Marziniak M, et al. Evidence-based patient information programme in early multiple sclerosis: a randomised controlled trial. J. Neurol. Neurosurg. Psychiatry. 2014;85:411-8.

254. Kaufman EM, Peshkin BN, Lawrence WF, Shelby R, Isaacs C, Brown K, et al. Development of an Interactive Decision Aid for Female BRCA1/BRCA2 Carriers. J. Genet. Couns. 2003;12:109-29.

255. Kellar I, Sutton S, Griffin S, Prevost AT, Kinmonth AL, Marteau TM. Evaluation of an informed choice invitation for type 2 diabetes screening. Patient Educ. Couns. 2008;72:232-8.

256. Mann E, Kellar I, Sutton S, Kinmonth AL, Hankins M, Griffin S, et al. Impact of informedchoice invitations on diabetes screening knowledge, attitude and intentions: an analogue study. 
BMC Public Health. 2010;10:768.

257. Marteau TM, Mann E, Prevost AT, Vasconcelos JC, Kellar I, Sanderson S, et al. Impact of an informed choice invitation on uptake of screening for diabetes in primary care (DICISION): randomised trial. BMJ. 2010;340:c2138.

258. Kellar I, Mann E, Kinmonth AL, Prevost AT, Sutton S, Marteau TM. Can informed choice invitations lead to inequities in intentions to make lifestyle changes among participants in a primary care diabetes screening programme? Evidence from a randomized trial. Public Health. 2011;125:645-52.

259. Kennedy ADM, Sculpher MJ, Coulter A, Dwyer N, Rees M, Abrams KR, et al. Effects of decision aids for menorrhagia on treatment choices, health outcomes, and costs: a randomized controlled trial. JAMA. 2002;288:2701-8.

260. Kennedy ADM, Sculpher MJ, Coulter A, Dwyer N, Rees M, Horsley S, et al. A multicentre randomised controlled trial assessing the costs and benefits of using structured information and analysis of women's preferences in the management of menorrhagia. Health Technol. Assess. ncbi.nlm.nih.gov; 2003;7:1-76.

261. Kiatpongsan S, Carlson K, Feibelmann S, Sepucha K. Decision aid reduces misperceptions about hormone therapy: a randomized controlled trial. Menopause. 2014;21:338.

262. Knapp P, Wanklyn P, Raynor DK, Waxman R. Developing and testing a patient information booklet for thrombolysis used in acute stroke. International Journal of Pharmacy Practice. 2010;18:362-9.

263. Köpke S, Richter T, Kasper J, Mühlhauser I, Flachenecker P, Heesen C. Implementation of a patient education program on multiple sclerosis relapse management. Patient Educ. Couns. 2012;86:91-7.

264. Krist AH, Woolf SH, Johnson RE, Kerns JW. Patient education on prostate cancer screening and involvement in decision making. Ann. Fam. Med. 2007;5:112-9.

265. Krones T, Keller H, Becker A, Sönnichsen A, Baum E, Donner-Banzhoff N. The theory of planned behaviour in a randomized trial of a decision aid on cardiovascular risk prevention. Patient Educ. Couns. 2010;78:169-76.

266. Kupke J, Wicht MJ, Stützer H, Derman SHM, Lichtenstein NV, Noack MJ. Does the use of a visualised decision board by undergraduate students during shared decision-making enhance patients' knowledge and satisfaction? - A randomised controlled trial. Eur. J. Dent. Educ. 2013;17:19-25.

267. Kuppermann M, Norton ME, Gates E, Gregorich SE, Learman LA, Nakagawa S, et al. Computerized Prenatal Genetic Testing Decision-Assisting Tool. Obstetrics \& Gynecology. 2009;113:53-63.

268. Kuppermann M, Pena S, Bishop JT, Nakagawa S, Gregorich SE, Sit A, et al. Effect of Enhanced Information, Values Clarification, and Removal of Financial Barriers on Use of Prenatal Genetic Testing: A Randomized Clinical Trial. JAMA. American Medical Association; 
2014;312:1210-7.

269. Norton ME, Nakagawa S, Kuppermann M. Women's Attitudes Regarding Prenatal Testing for a Range of Congenital Disorders of Varying Severity. J. Clin. Med. Res. 2014;3:144-52.

270. Labrecque M, Paunescu C, Plesu I, Stacey D, Légaré F. Evaluation of the effect of a patient decision aid about vasectomy on the decision-making process: a randomized trial. Contraception. 2010;82:556-62.

271. Lalonde L, O'Connor AM, Drake E, Duguay P, Lowensteyn I, Grover SA. Development and preliminary testing of a patient decision aid to assist pharmaceutical care in the prevention of cardiovascular disease. Pharmacotherapy. Wiley Online Library; 2004;24:909-22.

272. Lalonde L, O'Connor AM, Duguay P, Brassard J, Drake E, Grover SA. Evaluation of a decision aid and a personal risk profile in community pharmacy for patients considering options to improve cardiovascular health: the OPTIONS pilot study. Int. J. Pharm. Pract. 2006;14:51-62.

273. LaVista JM, Treise DM, Dunbar LN, Ritho J, Hartzema AG, Lottenberg R. Development and evaluation of a patient empowerment video to promote hydroxyurea adoption in sickle cell disease. J. Natl. Med. Assoc. Elsevier; 2009;101:251-7.

274. Lawrence VA, Streiner D, Hazuda HP, Naylor R, Levine M, Gafni A. A cross-cultural consumer-based decision aid for screening mammography. Prev. Med. 2000;30:200-8.

275. Lee BT, Chen C, Yueh JH, Nguyen M-D, Lin SJ, Tobias AM. Computer-based learning module increases shared decision making in breast reconstruction. Ann. Surg. Oncol. 2010;17:738-43.

276. Légaré F, O'Connor AM, Graham ID, Wells GA, Jacobsen MJ, Elmslie T, et al. The effect of decision aids on the agreement between women's and physicians' decisional conflict about hormone replacement therapy. Patient Educ. Couns. 2003;50:211-21.

277. Légaré F, Stacey D, Dodin S, O'Connor A, Richer M, Griffiths F, et al. Women's decision making about the use of natural health products at menopause: a needs assessment and patient decision aid. J. Altern. Complement. Med. 2007;13:741-9.

278. Légaré F, Dodin S, Stacey D, LeBlanc A, Tapp S. Patient decision aid on natural health products for menopausal symptoms: randomized controlled trial. Menopause Int. 2008;14:10510.

279. Menard P, Stacey D, Légare F, Woodend K. Evaluation of a natural health product decision aid: a tool for middle aged women considering menopausal symptom relief. Maturitas. 2010;65:366-71.

280. Légaré $F$, Labrecque $M$, LeBlanc A, Njoya $M$, Laurier $C$, Côté L, et al. Training family physicians in shared decision making for the use of antibiotics for acute respiratory infections: a pilot clustered randomized controlled trial. Health Expect. 2011;14 Suppl 1:96-110.

281. Leighl NB, Shepherd FA, Zawisza D, Burkes RL, Feld R, Waldron J, et al. Enhancing treatment decision-making: pilot study of a treatment decision aid in stage IV non-small cell lung cancer. Br. J. Cancer. 2008;98:1769-73. 
282. Leighl NB, Shepherd HL, Butow PN, Clarke SJ, McJannett M, Beale PJ, et al. Supporting treatment decision making in advanced cancer: a randomized trial of a decision aid for patients with advanced colorectal cancer considering chemotherapy. J. Clin. Oncol. 2011;29:2077-84.

283. Lenert LA, Cher DJ. Use of meta-analytic results to facilitate shared decision making. J. Am. Med. Inform. Assoc. 1999;6:412-9.

284. Lerman C, Lustbader E, Rimer B, Daly M, Miller S, Sands C, et al. Effects of individualized breast cancer risk counseling: a randomized trial. J. Natl. Cancer Inst. 1995;87:286-92.

285. Leung KY, Lee CP, Chan HY, Tang MHY, Lam YH, Lee A. Randomised trial comparing an interactive multimedia decision aid with a leaflet and a video to give information about prenatal screening for Down syndrome. Prenat. Diagn. 2004;24:613-8.

286. Lewis CL, Brenner AT, Griffith JM, Pignone MP. The uptake and effect of a mailed multimodal colon cancer screening intervention: a pilot controlled trial. Implement. Sci. 2008;3:32.

287. Lewis CL, Golin CE, DeLeon C, Griffith JM, Ivey J, Trevena L, et al. A targeted decision aid for the elderly to decide whether to undergo colorectal cancer screening: development and results of an uncontrolled trial. BMC Med. Inform. Decis. Mak. 2010;10:54.

288. Lewis C, Pignone M, Schild LA, Scott T, Winquist A, Rimer BK, et al. Effectiveness of a patient- and practice-level colorectal cancer screening intervention in health plan members: design and baseline findings of the CHOICE trial. Cancer. 2010;116:1664-73.

289. Miller DP Jr, Spangler JG, Case LD, Goff DC Jr, Singh S, Pignone MP. Effectiveness of a Web-Based Colorectal Cancer Screening Patient Decision Aid. Am. J. Prev. Med. Elsevier; 2011;40:608-15.

290. Pignone M, Winquist A, Schild LA, Lewis C, Scott T, Hawley J, et al. Effectiveness of a patient and practice-level colorectal cancer screening intervention in health plan members. Cancer. 2011;117:3352-62.

291. Li LC, Adam PM, Townsend AF, Lacaille D, Yousefi C, Stacey D, et al. Usability testing of ANSWER: a web-based methotrexate decision aid for patients with rheumatoid arthritis. BMC Med. Inform. Decis. Mak. 2013;13:131.

292. Li LC, Adam PM, Backman CL, Lineker S, Jones CA, Lacaille D, et al. Proof-of-concept study of a Web-based methotrexate decision aid for patients with rheumatoid arthritis. Arthritis Care Res. 2014;66:1472-81.

293. Liao L, Jollis JG, DeLong ER, Peterson ED, Morris KG, Mark DB. Impact of an interactive video on decision making of patients with ischemic heart disease. J. Gen. Intern. Med. 1996;11:373-6.

294. Morgan MW, Deber RB, Llewellyn-Thomas HA, Gladstone P, Cusimano RJ, O'Rourke K, et al. Randomized, controlled trial of an interactive videodisc decision aid for patients with ischemic heart disease. J. Gen. Intern. Med. 2000;15:685-93.

295. Loh A, Simon D, Wills CE, Kriston L, Niebling W, Härter M. The effects of a shared decision-making intervention in primary care of depression: a cluster-randomized controlled trial. 
Patient Educ. Couns. 2007;67:324-32.

296. Lurie JD, Spratt KF, Blood EA, Tosteson TD, Tosteson ANA, Weinstein JN. Effects of viewing an evidence-based video decision aid on patients' treatment preferences for spine surgery. Spine . 2011;36:1501-4.

297. Makoul G, Cameron KA, Baker DW, Francis L, Scholtens D, Wolf MS. A multimedia patient education program on colorectal cancer screening increases knowledge and willingness to consider screening among Hispanic/Latino patients. Patient Educ. Couns. 2009;76:220-6.

298. Mancini J, Noguès $C$, Adenis $C$, Berthet $P$, Bonadona $V$, Chompret $A$, et al. Impact of an information booklet on satisfaction and decision-making about BRCA genetic testing. Eur. J. Cancer. 2006;42:871-81.

299. Manne SL, Coups EJ, Markowitz A, Meropol NJ, Haller D, Jacobsen PB, et al. A randomized trial of generic versus tailored interventions to increase colorectal cancer screening among intermediate risk siblings. Ann. Behav. Med. 2009;37:207-17.

300. Manne SL, Meropol NJ, Weinberg DS, Vig H, Ali-Khan Catts Z, Manning C, et al. Facilitating informed decisions regarding microsatellite instability testing among high-risk individuals diagnosed with colorectal cancer. J. Clin. Oncol. 2010;28:1366-72.

301. Man-Son-Hing M, Laupacis A, O'Connor AM, Biggs J. A patient decision aid regarding antithrombotic therapy for stroke prevention in atrial fibrillation: a randomized controlled trial. JAMA [Internet]. 1999; Available from: http://jamanetwork.com/journals/jama/fullarticle/191331

302. Man-Son-Hing M, Laupacis A, O'Connor AM, Hart RG, Feldman G, Blackshear JL, et al. Development of a decision aid for patients with atrial fibrillation who are considering antithrombotic therapy. J. Gen. Intern. Med. Springer-Verlag; 2000;15:723-30.

303. McAlister FA, Man-Son-Hing M, Straus SE, Ghali WA, Anderson D, Majumdar SR, et al. Impact of a patient decision aid on care among patients with nonvalvular atrial fibrillation: a cluster randomized trial. CMAJ. 2005;173:496-501.

304. Masaracchia C, D'Addio L, Federici A. Informazione scritta valutazione di un opuscolo informativo per le persone che si sottopongono a colonscopia. Assist. Inferm. Ric. 1999;18:1406.

305. Maslin AM, Baum M, Walker JS, A'Hern R, Prouse A. Using an interactive video disk in breast cancer patient support. Nurs. Times. 1998;94:52-5.

306. Mathers N, Ng CJ, Campbell MJ, Colwell B, Brown I, Bradley A. Clinical effectiveness of a patient decision aid to improve decision quality and glycaemic control in people with diabetes making treatment choices: a cluster randomised controlled trial (PANDAs) in general practice. BMJ Open [Internet]. 2012;2. Available from: http://dx.doi.org/10.1136/bmjopen-2012-001469

307. Ng CJ, Mathers N, Bradley A, Colwell B. A "combined framework" approach to developing a patient decision aid: the PANDAs model. BMC Health Serv. Res. 2014;14:503.

308. Mathieu E, Barratt A, Davey HM, McGeechan K, Howard K, Houssami N. Informed choice in mammography screening: a randomized trial of a decision aid for 70-year-old women. Arch. 
Intern. Med. 2007;167:2039-46.

309. Mathieu E, Barratt AL, McGeechan K, Davey HM, Howard K, Houssami N. Helping women make choices about mammography screening: an online randomized trial of a decision aid for 40-year-old women. Patient Educ. Couns. 2010;81:63-72.

310. Matlock DD, Keech TAE, McKenzie MB, Bronsert MR, Nowels CT, Kutner JS. Feasibility and acceptability of a decision aid designed for people facing advanced or terminal illness: a pilot randomized trial. Health Expect. 2014;17:49-59.

311. Mayberry $\mathrm{H}$, Mayberry JF. The role of an information sheet in patient led decision making about sedation and anaesthesia during gastroscopy. Int. J. Clin. Pract. 2008;62:143-7.

312. Mayer DK, Ratichek S, Berhe H, Stewart S, McTavish F, Gustafson D, et al. Development of a health-related website for parents of children receiving hematopoietic stem cell transplant: HSCT-CHESS. J. Cancer Surviv. 2010;4:67-73.

313. McCaffery K, Irwig L. Australian women's needs and preferences for information about human papillomavirus in cervical screening. J. Med. Screen. 2005;12:134-41.

314. McCaffery K, Waller J, Nazroo J, Wardle J. Social and psychological impact of HPV testing in cervical screening: a qualitative study. Sex. Transm. Infect. 2006;82:169-74.

315. McCaffery KJ, Irwig L, Chan SF, Macaskill P, Barratt A, Lewicka M, et al. HPV testing versus repeat Pap testing for the management of a minor abnormal Pap smear: Evaluation of a decision aid to support informed choice. Patient Educ. Couns. Elsevier; 2008;73:473-81.

316. McCaffery KJ, Irwig L, Turner R, Chan SF, Macaskill P, Lewicka M, et al. Psychosocial outcomes of three triage methods for the management of borderline abnormal cervical smears: an open randomised trial. BMJ. 2010;340:b4491.

317. McKay A, Martin W, Latosinsky S. How Should We Inform Women at Higher Risk of Breast Cancer About Tamoxifen? An Approach with a Decision Guide. Breast Cancer Res. Treat. Kluwer Academic Publishers; 2005;94:153-9.

318. Metcalfe KA, Poll A, O'Connor A, Gershman S, Armel S, Finch A, et al. Development and testing of a decision aid for breast cancer prevention for women with a BRCA1 or BRCA2 mutation. Clin. Genet. 2007;72:208-17.

319. Michie S, Smith D, Marteau TM. Patient decision making: An evaluation of two different methods of presenting information about a screening test. Br. J. Health Psychol. Blackwell Publishing Ltd; 1997;2:317-26.

320. Miller SM, Fleisher L, Roussi P, Buzaglo JS, Schnoll R, Slater E, et al. Facilitating informed decision making about breast cancer risk and genetic counseling among women calling the NCl's Cancer Information Service. J. Health Commun. 2005;10 Suppl 1:119-36.

321. Milne J, Gafni A, Lu D, Wood S, Sauve R, Ross S. Developing and pre-testing a decision board to facilitate informed choice about delivery approach in uncomplicated pregnancy. BMC Pregnancy Childbirth. 2009;9:50. 
322. Mitchell SL, Tetroe J, O'connor AM. A Decision Aid for Long-Term Tube Feeding in Cognitively Impaired Older Persons. J. Am. Geriatr. Soc. Wiley Online Library; 2001;49:313-6.

323. Hanson LC, Carey TS, Caprio AJ, Lee TJ, Ersek M, Garrett J, et al. Improving decisionmaking for feeding options in advanced dementia: a randomized, controlled trial. J. Am. Geriatr. Soc. 2011;59:2009-16.

324. Snyder EA, Caprio AJ, Wessell K, Lin FC, Hanson LC. Impact of a decision aid on surrogate decision-makers' perceptions of feeding options for patients with dementia. J. Am. Med. Dir. Assoc. 2013;14:114-8.

325. Molenaar S, Sprangers M, Rutgers E, Mulder J, Luiten E, de Haes H. An interactive CDROM concerning the choice between breast-conserving therapy and mastectomy: positive evaluations from patients and surgeons. Nederlands Tijdschrift Voor Geneeskunde. 2001;145:1004-8.

326. Molenaar S, Sprangers MA, Rutgers EJ, Luiten EJ, Mulder J, Bossuyt PM, et al. Decision support for patients with early-stage breast cancer: effects of an interactive breast cancer CDROM on treatment decision, satisfaction, and quality of life. J. Clin. Oncol. 2001;19:1676-87.

327. Molenaar S, Oort F, Sprangers M, Rutgers E, Luiten E, Mulder J, et al. Predictors of patients' choices for breast-conserving therapy or mastectomy: a prospective study. Br. J. Cancer. 2004;90:2123-30.

328. Molenaar S, Sprangers M, Oort F, Rutgers E, Luiten E, Mulder J, et al. Exploring the black box of a decision aid: what information do patients select from an interactive Cd-Rom on treatment options in breast cancer? Patient Educ. Couns. 2007;65:122-30.

329. Montgomery AA, Fahey T, Peters TJ. A factorial randomised controlled trial of decision analysis and an information video plus leaflet for newly diagnosed hypertensive patients. Br. J. Gen. Pract. 2003;53:446-53.

330. Emmett CL, Montgomery AA, Peters TJ, Fahey T. Three-year follow-up of a factorial randomised controlled trial of two decision aids for newly diagnosed hypertensive patients. Br. J. Gen. Pract. 2005;55:551-3.

331. Montori VM, Breslin M, Maleska M, Weymiller AJ. Creating a conversation: insights from the development of a decision aid. PLoS Med. 2007;4:e233.

332. Weymiller AJ, Montori VM, Jones LA, Gafni A, Guyatt GH, Bryant SC, et al. Helping patients with type 2 diabetes mellitus make treatment decisions: statin choice randomized trial. Arch. Intern. Med. 2007;167:1076-82.

333. Jones LA, Weymiller AJ, Shah N, Bryant SC, Christianson TJH, Guyatt GH, et al. Should clinicians deliver decision aids? Further exploration of the statin choice randomized trial results. Med. Decis. Making. 2009;29:468-74.

334. Nannenga MR, Montori VM, Weymiller AJ, Smith SA, Christianson TJH, Bryant SC, et al. A treatment decision aid may increase patient trust in the diabetes specialist. The Statin Choice randomized trial. Health Expect. 2009;12:38-44. 
335. Mann DM, Ponieman D, Montori VM, Arciniega J, McGinn T. The Statin Choice decision aid in primary care: a randomized trial. Patient Educ. Couns. 2010;80:138-40.

336. Müller EV, Schmacke N, Kolip P, Berger B. [Desirable, unfamiliar and in need of communication - the evidence-based decision aid of the Institute for Quality and Efficiency in Health Care (IQWiG)]. Z. Evid. Fortbild. Qual. Gesundhwes. 2012;106:290-4.

337. Murray E, Davis H, Tai SS, Coulter A, Gray A, Haines A. Randomised controlled trial of an interactive multimedia decision aid on benign prostatic hypertrophy in primary care. BMJ. 2001;323:493-6.

338. Murray E, Davis H, Tai SS, Coulter A, Gray A, Haines A. Randomised controlled trial of an interactive multimedia decision aid on hormone replacement therapy in primary care. BMJ. $2001 ; 323: 490-3$.

339. Myers RE, Daskalakis C, Cocroft J, Kunkel EJS, Delmoor E, Liberatore M, et al. Preparing African-American men in community primary care practices to decide whether or not to have prostate cancer screening. J. Natl. Med. Assoc. 2005;97:1143-54.

340. Myers RE, Daskalakis C, Kunkel EJS, Cocroft JR, Riggio JM, Capkin M, et al. Mediated decision support in prostate cancer screening: a randomized controlled trial of decision counseling. Patient Educ. Couns. 2011;83:240-6.

341. Nagle C, Lewis S, Meiser B, Metcalfe S, Carlin JB, Bell R, et al. Evaluation of a decision aid for prenatal testing of fetal abnormalities: a cluster randomised trial [ISRCTN22532458]. BMC Public Health. 2006;6:96.

342. Nagle C, Gunn J, Bell R, Lewis S, Meiser B, Metcalfe S, et al. Use of a decision aid for prenatal testing of fetal abnormalities to improve women's informed decision making: a cluster randomised controlled trial [ISRCTN22532458]. BJOG. 2008;115:339-47.

343. Nassar N, Roberts CL, Raynes-Greenow CH, Barratt A. Development and pilot-testing of a decision aid for women with a breech-presenting baby. Midwifery. 2007;23:38-47.

344. Nassar N, Roberts CL, Raynes-Greenow CH, Barratt A, Peat B, Decision Aid for Breech Presentation Trial Collaborators. Evaluation of a decision aid for women with breech presentation at term: a randomised controlled trial [ISRCTN14570598]. BJOG. 2007;114:32533.

345. Nozaki K, Okubo C, Yokoyama Y, Morita A, Akamatsu R, Nakayama T, et al. Examination of the effectiveness of DVD decision support tools for patients with unruptured cerebral aneurysms. Neurol. Med. Chir. 2007;47:531-6; discussion 536.

346. O'Connor AM, Tugwell P, Wells GA, Elmslie T, Jolly E, Hollingworth G, et al. A decision aid for women considering hormone therapy after menopause: decision support framework and evaluation. Patient Educ. Couns. 1998;33:267-79.

347. O'Connor AM, Tugwell P, Wells GA, Elmslie T, Jolly E, Hollingworth G, et al. Randomized Trial of a Portable, Self-administered Decision Aid for Postmenopausal Women Considering Long-term Preventive Hormone Therapy. Med. Decis. Making. 1998;18:295-303. 
348. Rostom A, O'Connor A, Tugwell P, Wells G. A randomized trial of a computerized versus an audio-booklet decision aid for women considering post-menopausal hormone replacement therapy. Patient Educ. Couns. 2002;46:67-74.

349. Oakley S, Walley T. A pilot study assessing the effectiveness of a decision aid on patient adherence with oral bisphosphonate medication. Pharm. J. [Internet]. Pharmaceutical Journal; 2006;276. Available from: http://cat.inist.fr/?aModele=afficheN\&cpsidt=17761826

350. O'Cathain A, Walters SJ, Nicholl JP, Thomas KJ, Kirkham M. Use of evidence based leaflets to promote informed choice in maternity care: randomised controlled trial in everyday practice. BMJ. 2002;324:643.

351. O'Connor RN, Annette M, Wells GA, Tugwell P, Laupacis A, Elmslie T, et al. The effects of an "explicit" values clarification exercise in a woman's decision aid regarding postmenopausal hormone therapy. Health Expectations. 1999;2:21-32.

352. Ogle K, Greene DD, Winn B, Mishkin D, Bricker LG, Lambing AK. Completing a life: development of an interactive multimedia CD-ROM for patient and family education in end-of-life care. J. Palliat. Med. 2003;6:841-50.

353. Onel E, Hamond C, Wasson JH, Berlin BB, Ely MG, Laudone VP, et al. Assessment of the feasibility and impact of shared decision making in prostate cancer. Urology. 1998;51:63-6.

354. Ossebaard HC, van Gemert-Pijnen JEWC, Sorbi MJ, Seydel ER. A study of a Dutch online decision aid for parents of children with ADHD. J. Telemed. Telecare. 2010;16:15-9.

355. Owens BH, Robbins KC. CHESS(R): Comprehensive Health Enhancement Support System for Women with Breast Cancer. Plast. Surg. Nurs. 1996;16:172.

356. Ozanne EM, Annis C, Adduci K, Showstack J, Esserman L. Pilot trial of a computerized decision aid for breast cancer prevention. Breast J. 2007;13:147-54.

357. Peate M, Meiser B, Friedlander M, Saunders C, Martinello R, Wakefield CE, et al. Development and pilot testing of a fertility decision aid for young women diagnosed with early breast cancer. Breast J. 2011;17:112-4.

358. Peate M, Meiser B, Friedlander M, Zorbas H, Rovelli S, Sansom-Daly U, et al. It's now or never: fertility-related knowledge, decision-making preferences, and treatment intentions in young women with breast cancer--an Australian fertility decision aid collaborative group study. J. Clin. Oncol. 2011;29:1670-7.

359. Peate M, Meiser B, Cheah BC, Saunders C, Butow P, Thewes B, et al. Making hard choices easier: a prospective, multicentre study to assess the efficacy of a fertility-related decision aid in young women with early-stage breast cancer. Br. J. Cancer. 2012;106:1053-61.

360. Peele PB, Siminoff LA, Xu Y, Ravdin PM. Decreased use of adjuvant breast cancer therapy in a randomized controlled trial of a decision aid with individualized risk information. Med. Decis. Making. 2005;25:301-7.

361. Siminoff LA, Gordon NH, Silverman P, Budd T, Ravdin PM. A decision aid to assist in adjuvant therapy choices for breast cancer. Psychooncology. 2006;15:1001-13. 
362. Vickers AJ, Elkin EB, Peele PB, Dickler M, Siminoff LA. Long-term health outcomes of a decision aid: data from a randomized trial of adjuvant! In women with localized breast cancer. Med. Decis. Making. 2009;29:461-7.

363. Pell I, Dowie J, Clarke A, Kennedy A, Bhavnani V. Development and preliminary evaluation of a clinical guidance programme for the decision about prophylactic oophorectomy in women undergoing a hysterectomy. Qual. Saf. Health Care. 2002;11:32-8.

364. Pencille LJ, Campbell ME, Van Houten HK, Shah ND, Mullan RJ, Swiglo BA, et al. Protocol for the Osteoporosis Choice trial. A pilot randomized trial of a decision aid in primary care practice. Trials. 2009;10:113.

365. Montori VM, Shah ND, Pencille LJ, Branda ME, Van Houten HK, Swiglo BA, et al. Use of a decision aid to improve treatment decisions in osteoporosis: the osteoporosis choice randomized trial. Am. J. Med. 2011;124:549-56.

366. Perestelo-Perez L, Perez-Ramos J, Gonzalez-Lorenzo M, Rivero-Santana A, SerranoAguilar P. Decision aids for patients facing health treatment decisions in Spain: preliminary results. Patient Educ. Couns. 2010;80:364-71.

367. Permuth-Wey J, Vadaparampil S, Rumphs A, Kinney AY, Pal T. Development of a culturally tailored genetic counseling booklet about hereditary breast and ovarian cancer for Black women. Am. J. Med. Genet. A. 2010;152A:836-45.

368. Peshkin BN, DeMarco TA, Tercyak KP. On the development of a decision support intervention for mothers undergoing BRCA1/2 cancer genetic testing regarding communicating test results to their children. Fam. Cancer. Springer Netherlands; 2010;9:89-97.

369. Peterson SK, Pentz RD, Blanco AM, Ward PA, Watts BG, Marani SK, et al. Evaluation of a decision aid for families considering p53 genetic counseling and testing. Genet. Med. Nature Publishing Group; 2006;8:226-33.

370. Pierce MA, Hess EP, Kline JA, Shah ND, Breslin M, Branda ME, et al. The Chest Pain Choice trial: a pilot randomized trial of a decision aid for patients with chest pain in the emergency department. Trials. 2010;11:57.

371. Hess EP, Knoedler MA, Shah ND, Kline JA, Breslin M, Branda ME, et al. The chest pain choice decision aid: a randomized trial. Circ. Cardiovasc. Qual. Outcomes. 2012;5:251-9.

372. Pignone M, Harris R, Kinsinger L. Videotape-based decision aid for colon cancer screening: a randomized, controlled trial. Ann. Intern. Med. 2000;133:761-9.

373. Kim J, Whitney A, Hayter S, Lewis C, Campbell M, Sutherland L, et al. Development and initial testing of a computer-based patient decision aid to promote colorectal cancer screening for primary care practice. BMC Med. Inform. Decis. Mak. 2005;5:36.

374. Griffith JM, Lewis CL, Brenner ART, Pignone MP. The effect of offering different numbers of colorectal cancer screening test options in a decision aid: a pilot randomized trial. BMC Med. Inform. Decis. Mak. 2008;8:4.

375. Griffith JM, Fichter M, Fowler FJ, Lewis C, Pignone MP. Should a colon cancer screening 
decision aid include the option of no testing? A comparative trial of two decision aids. BMC Med. Inform. Decis. Mak. 2008;8:10.

376. Pignone M, Sheridan SL, Lee YZ, Kuo J, Phillips C, Mulrow C, et al. Heart to Heart: a computerized decision aid for assessment of coronary heart disease risk and the impact of riskreduction interventions for primary prevention. Prev. Cardiol. 2004;7:26-33.

377. Sheridan SL, Shadle J, Simpson RJ Jr, Pignone MP. The impact of a decision aid about heart disease prevention on patients' discussions with their doctor and their plans for prevention: a pilot randomized trial. BMC Health Serv. Res. 2006;6:121.

378. Sheridan SL, Turner A, Pignone MP, Fowler B, Kibe J, Carr C, et al. The Development of a Comprehensive Intervention to Improve Decision-making and Adherence to Coronary Heart Disease Risk Reducing Strategies: Heart to Heart 2. Patient Educ Couns. 2009, in press;

379. Sheridan SL, Griffith JM, Behrend L, Gizlice Z, Jianwen Cai, Pignone MP. Effect of adding a values clarification exercise to a decision aid on heart disease prevention: a randomized trial. Med. Decis. Making. 2010;30:E28-39.

380. Sheridan SL, Draeger LB, Pignone MP, Keyserling TC, Simpson RJ Jr, Rimer B, et al. A randomized trial of an intervention to improve use and adherence to effective coronary heart disease prevention strategies. BMC Health Serv. Res. 2011;11:331.

381. Protheroe J, Bower P, Chew-Graham C. The use of mixed methodology in evaluating complex interventions: identifying patient factors that moderate the effects of a decision aid. Fam. Pract. 2007;24:594-600.

382. Protheroe J, Bower P, Chew-Graham C, Peters TJ, Fahey T. Effectiveness of a computerized decision aid in primary care on decision making and quality of life in menorrhagia: results of the MENTIP randomized controlled trial. Med. Decis. Making. 2007;27:575-84.

383. Prunty MC, Sharpe L, Butow P, Fulcher G. The motherhood choice: a decision aid for women with multiple sclerosis. Patient Educ. Couns. 2008;71:108-15.

384. Raats CJI, van Veenendaal H, Versluijs MM, Burgers JS. A generic tool for development of decision aids based on clinical practice guidelines. Patient Educ. Couns. Elsevier; 2008;73:4137.

385. Rapport F, Iredale R, Jones W, Sivell S, Edwards A, Gray J, et al. Decision aids for familial breast cancer: exploring women's views using focus groups. Health Expect. 2006;9:232-44.

386. Raynes-Greenow CH, Roberts CL, Nassar N, Trevena L. Do audio-guided decision aids improve outcomes? A randomized controlled trial of an audio-guided decision aid compared with a booklet decision aid for Australian women considering labour analgesia. Health Expect. 2009;12:407-16.

387. Raynes-Greenow CH, Nassar N, Torvaldsen S, Trevena L, Roberts CL. Assisting informed decision making for labour analgesia: a randomised controlled trial of a decision aid for labour analgesia versus a pamphlet. BMC Pregnancy Childbirth. 2010;10:15.

388. Redfern J, Ellis E, Briffa T, Freedman SB. Development and testing of innovative patient 
resources for the management of coronary heart disease (CHD): a descriptive study. BMC Health Serv. Res. 2006;6:95.

389. Renzi C, Di Pietro C, Gisondi P, Chinni LM, Fazio M, Ianni A, et al. Insufficient Knowledge Among Psoriasis Patients Can Represent a Barrier to Participation in Decision-making. Acta Derm. Venereol. 2006;86:528-34.

390. Reuland DS, Ko LK, Fernandez A, Braswell LC, Pignone M. Testing a Spanish-language colorectal cancer screening decision aid in Latinos with limited English proficiency: results from a pre-post trial and four month follow-up survey. BMC Med. Inform. Decis. Mak. 2012;12:53.

391. Ko LK, Reuland D, Jolles M, Clay R, Pignone M. Cultural and linguistic adaptation of a multimedia colorectal cancer screening decision aid for Spanish-speaking Latinos. J. Health Commun. 2014;19:192-209.

392. Rhee H, Hollen PJ, Belyea MJ, Sutherland MA. Decision-Making Program for Rural Adolescents With Asthma: A Pilot Study. Journal of Pediatric Nursing: Nursing Care of Children and Families. Elsevier; 2008;23:439-50.

393. Ronda G, Grispen JEJ, Ickenroth MHP, Dinant G-J, De Vries NK, Van der Weijden T. The effects of a web-based decision aid on the intention to diagnostic self-testing for cholesterol and diabetes: a randomized controlled trial. BMC Public Health. 2014;14:921.

394. Ickenroth MHP, Grispen JEJ, Ronda G, Dinant G-J, de Vries NK, der Weijden T van. Educating consumers in self-testing: The development of an online decision aid. Health Educ. J. 2015;74:485-95.

395. Ross L, Ashford AD, Bleechington SJ, Dark T, Erwin DO. Applicability of a video intervention to increase informed decision making for prostate-specific antigen testing. J. Natl. Med. Assoc. Elsevier; 2010;102:228-36.

396. Rothert ML, Holmes-Rovner M, Rovner D, Kroll J, Breer L, Talarczyk G, et al. An educational intervention as decision support for menopausal women. Res. Nurs. Health. 1997;20:377-87.

397. Holmes-Rovner M, Kroll J, Rovner DR, Schmitt N, Rothert M, Padonu G, et al. Patient decision support intervention: increased consistency with decision analytic models. Med. Care. 1999;37:270-84.

398. Rubel SK, Miller JW, Stephens RL, Xu Y, Scholl LE, Holden EW, et al. Testing the effects of a decision aid for prostate cancer screening. J. Health Commun. 2010;15:307-21.

399. Ruland CM. Decision Support for Patient Preference-based Care Planning. Journal of the American Medical Informatics Association. 1999;6:304-12.

400. Ruthman JL, Ferrans CE. Efficacy of a video for teaching patients about prostate cancer screening and treatment. Am. J. Health Promot. 2004;18:292-5.

401. Saver BG, Gustafson D, Taylor TR, Hawkins RP, Woods NF, Dinauer S, et al. A tale of two studies: The importance of setting, subjects and context in two randomized, controlled trials of a web-based decision support for perimenopausal and postmenopausal health decisions. Patient 
Educ. Couns. Elsevier; 2007;66:211-22.

402. Sawka CA, Goel V, Mahut CA, Taylor GA, Thiel EC, O'Connor AM, et al. Development of a patient decision aid for choice of surgical treatment for breast cancer. Health Expect. 1998;1:23-36.

403. Goel V, Sawka CA, Thiel EC, Gort EH, O'Connor AM. Randomized trial of a patient decision aid for choice of surgical treatment for breast cancer. Med. Decis. Making. 2001;21:16.

404. Sawka AM, Straus S, Gafni A, Brierley JD, Tsang RW, Rotstein L, et al. How can we meet the information needs of patients with early stage papillary thyroid cancer considering radioactive iodine remnant ablation? Clin. Endocrinol. . 2011;74:419-23.

405. Sawka AM, Straus S, Gafni A, Meiyappan S, O'Brien MA, Brierley JD, et al. A usability study of a computerized decision aid to help patients with, early stage papillary thyroid carcinoma in, decision-making on adjuvant radioactive iodine treatment. Patient Educ. Couns. 2011;84:e24-7.

406. Sawka AM, Straus S, Rotstein L, Brierley JD, Tsang RW, Asa S, et al. Randomized controlled trial of a computerized decision aid on adjuvant radioactive iodine treatment for patients with early-stage papillary thyroid cancer. J. Clin. Oncol. 2012;30:2906-11.

407. Schackmann EA, Munoz DF, Mills MA, Plevritis SK, Kurian AW. Feasibility evaluation of an online tool to guide decisions for BRCA1/2 mutation carriers. Fam. Cancer. 2013;12:65-73.

408. Schapira MM, VanRuiswyk J. The effect of an illustrated pamphlet decision-aid on the use of prostate cancer screening tests. J. Fam. Pract. 2000;49:418-24.

409. Schapira MM, Meade C, Nattinger AB. Enhanced decision-making: the use of a videotape decision-aid for patients with prostate cancer. Patient Educ. Couns. 1997;30:119-27.

410. Schapira MM, Gilligan MA, McAuliffe T, Garmon G, Carnes M, Nattinger AB. Decisionmaking at menopause: A randomized controlled trial of a computer-based hormone therapy decision-aid. Patient Educ. Couns. Elsevier; 2007;67:100-7.

411. Schonberg MA, Hamel MB, Davis RB, Griggs MC, Wee CC, Fagerlin A, et al. Development and evaluation of a decision aid on mammography screening for women 75 years and older. JAMA Intern. Med. 2014;174:417-24.

412. Schoorel ENC, Vankan E, Scheepers HCJ, Augustijn BCC, Dirksen CD, de Koning M, et al. Involving women in personalised decision-making on mode of delivery after caesarean section: the development and pilot testing of a patient decision aid. BJOG. 2014;121:202-9.

413. Schroy PC 3rd, Emmons K, Peters E, Glick JT, Robinson PA, Lydotes MA, et al. The impact of a novel computer-based decision aid on shared decision making for colorectal cancer screening: a randomized trial. Med. Decis. Making. 2011;31:93-107.

414. Schroy PC III, Emmons KM, Peters E, Glick JT, Robinson PA, Lydotes MA, et al. AidAssisted Decision Making and Colorectal Cancer Screening. Am. J. Prev. Med. 2012;43:57383. 
415. Schroy PC 3rd, Mylvaganam S, Davidson P. Provider perspectives on the utility of a colorectal cancer screening decision aid for facilitating shared decision making. Health Expect. 2014;17:27-35.

416. Schwalm J-D, Stacey D, Pericak D, Natarajan MK. Radial Artery Versus Femoral Artery Access Options in Coronary Angiogram Procedures. Circ. Cardiovasc. Qual. Outcomes. American Heart Association, Inc.; 2012;5:260-6.

417. Schwartz LM, Woloshin S, Welch HG. Using a Drug Facts Box to Communicate Drug Benefits and Harms. Ann. Intern. Med. 2009;150:516.

418. Schwartz MD, Valdimarsdottir HB, DeMarco TA, Peshkin BN, Lawrence W, Rispoli J, et al. Randomized trial of a decision aid for BRCA1/BRCA2 mutation carriers: impact on measures of decision making and satisfaction. Health Psychol. 2009;28:11-9.

419. Sepucha KR, Ozanne EM. Is there a role for decision aids in advanced breast cancer? Med. Decis. Making. 2009;29:475.

420. Shaffer VA, Owens J, Zikmund-Fisher BJ. The effect of patient narratives on information search in a web-based breast cancer decision aid: an eye-tracking study. J. Med. Internet Res. 2013;15:e273.

421. Shaw MJ, Beebe TJ, Tomshine PA, Adlis SA, Cass OW. A randomized, controlled trial of interactive, multimedia software for patient colonoscopy education. J. Clin. Gastroenterol. 2001;32:142-7.

422. Sheppard VB, Williams KP, Harrison TM, Jennings Y, Lucas W, Stephen J, et al. Development of decision-support intervention for Black women with breast cancer. Psychooncology. 2010;19:62-70.

423. Sheridan SL, Felix K, Pignone MP, Lewis CL. Information needs of men regarding prostate cancer screening and the effect of a brief decision aid. Patient Educ. Couns. 2004;54:345-51.

424. Sherman KA, Harcourt DM, Lam TC, Shaw L-K, Boyages J. BRECONDA: development and acceptability of an interactive decisional support tool for women considering breast reconstruction. Psychooncology. 2014;23:835-8.

425. Shorten A, Chamberlain M, Shorten B, Kariminia A. Making choices for childbirth: development and testing of a decision-aid for women who have experienced previous caesarean. Patient Educ. Couns. 2004;52:307-13.

426. Shorten A, Shorten B, Keogh J, West S, Morris J. Making choices for childbirth: a randomized controlled trial of a decision-aid for informed birth after cesarean. Birth. 2005;32:252-61.

427. Simon D, Kriston L, von Wolff A, Buchholz A, Vietor C, Hecke T, et al. Effectiveness of a web-based, individually tailored decision aid for depression or acute low back pain: a randomized controlled trial. Patient Educ. Couns. 2012;87:360-8.

428. Smith SK, Trevena L, Nutbeam D, Barratt A, McCaffery KJ. Information needs and preferences of low and high literacy consumers for decisions about colorectal cancer screening: 
utilizing a linguistic model. Health Expect. 2008;11:123-36.

429. Trevena LJ, Irwig L, Barratt A. Randomized trial of a self-administered decision aid for colorectal cancer screening. J. Med. Screen. 2008;15:76-82.

430. Smith SK, Trevena L, Barratt A, Dixon A, Nutbeam D, Simpson JM, et al. Development and preliminary evaluation of a bowel cancer screening decision aid for adults with lower literacy.

Patient Educ. Couns. 2009;75:358-67.

431. Smith SK, Trevena L, Simpson JM, Barratt A, Nutbeam D, McCaffery KJ. A decision aid to support informed choices about bowel cancer screening among adults with low education: randomised controlled trial. BMJ. 2010;341:c5370.

432. Smith TJ, Dow LA, Virago EA, Khatcheressian J, Matsuyama R, Lyckholm LJ. A pilot trial of decision aids to give truthful prognostic and treatment information to chemotherapy patients with advanced cancer. J. Support. Oncol. 2011;9:79-86.

433. Solberg LI, Asche SE, Sepucha K, Thygeson NM, Madden JE, Morrissey L, et al. Informed choice assistance for women making uterine fibroid treatment decisions: a practical clinical trial. Med. Decis. Making. 2010;30:444-52.

434. Sorenson JR, Lakon C, Spinney T, Jennings-Grant T. Assessment of a decision aid to assist genetic testing research participants in the informed consent process. Genet. Test. 2004;8:336-46.

435. Spunt BS, Deyo RA, Taylor VM, Leek KM, Goldberg HI, Mulley AG. An interactive videodisc program for low back pain patients. Health Educ. Res. 1996;11:535-41.

436. Deyo RA, Cherkin DC, Weinstein J, Howe J, Ciol M, Mulley AG Jr. Involving patients in clinical decisions: impact of an interactive video program on use of back surgery. Med. Care. 2000;38:959-69.

437. Phelan EA, Deyo RA, Cherkin DC, Weinstein JN, Ciol MA, Kreuter W, et al. Helping patients decide about back surgery: a randomized trial of an interactive video program. Spine. 2001;26:206-11.

438. Sridhar A, Chen A, Forbes ER, Glik D. Mobile application for information on reversible contraception: a randomized controlled trial. Am. J. Obstet. Gynecol. Elsevier; 2015;212:774.e1-774.e7.

439. Stacey D, O'Connor AM, DeGrasse C, Verma S. Development and evaluation of a breast cancer prevention decision aid for higher-risk women. Health Expect. 2003;6:3-18.

440. Stacey D, Hawker G, Dervin G, Tugwell P, Boland L, Pomey M-P, et al. Decision aid for patients considering total knee arthroplasty with preference report for surgeons: a pilot randomized controlled trial. BMC Musculoskelet. Disord. 2014;15:54.

441. Stalmeier PFM, Roosmalen MS. Concise evaluation of decision aids. Patient Educ. Couns. 2009;74:104-9.

442. Stalmeier PFM, Unic IJ, Verhoef LCG, Daal WAJV. Evaluation of a Shared Decision 
Making Program for Women Suspected to Have a Genetic Predisposition to Breast Cancer. Med. Decis. Making. 1999;19:230-41.

443. Steckelberg A, Kasper J, Redegeld M, Mühlhauser I. Risk information - barrier to informed choice? A focus group study. Soz.-Präventivmed. Birkhäuser-Verlag; 2004;49:375-80.

444. Steckelberg A, Hülfenhaus C, Haastert B, Mühlhauser I. Effect of evidence based risk information on "informed choice" in colorectal cancer screening: randomised controlled trial. BMJ. 2011;342:d3193.

445. Stein RA, Sharpe L, Bell ML, Boyle FM, Dunn SM, Clarke SJ. Randomized controlled trial of a structured intervention to facilitate end-of-life decision making in patients with advanced cancer. J. Clin. Oncol. 2013;31:3403-10.

446. Stephens RL, Xu Y, Volk RJ, Scholl LE, Kamin SL, Holden EW, et al. Influence of a patient decision aid on decisional conflict related to PSA testing: a structural equation model. Health Psychol. 2008;27:711-21.

447. Stiggelbout AM, Molewijk AC, Otten W, Van Bockel JH, Bruijninckx CMA, Van der Salm I, et al. The impact of individualized evidence-based decision support on aneurysm patients' decision making, ideals of autonomy, and quality of life. Med. Decis. Making. 2008;28:751-62.

448. Stirling C, Leggett S, Lloyd B, Scott J, Blizzard L, Quinn S, et al. Decision aids for respite service choices by carers of people with dementia: development and pilot RCT. BMC Med. Inform. Decis. Mak. 2012;12:21.

449. Street RL Jr, Voigt B, Geyer C Jr, Manning T, Swanson GP. Increasing patient involvement in choosing treatment for early breast cancer. Cancer. 1995;76:2275-85.

450. Sudore RL, Knight SJ, McMahan RD, Feuz M, Farrell D, Miao Y, et al. A novel website to prepare diverse older adults for decision making and advance care planning: a pilot study. J. Pain Symptom Manage. 2014;47:674-86.

451. Sullivan SM, McCarthy AE, Chambers LW, O'Connor A, Knoefel F, Sutherland J, et al. Development and evaluation of a decision aid about influenza prevention for healthcare workers. Can J Infect Control. 2007;22:203-10.

452. McCarthy AE, Lafleur C, Sutherland J, Lam P-P, Roth V, O'Connor AM, et al. Helping healthcare workers decide: evaluation of an influenza immunization decision tool. Can. J. Infect. Control. 2010;25:21-4.

453. Chambers LW, Wilson K, Hawken S, Puxty J, Crowe L, Lam P-P, et al. Impact of the Ottawa Influenza Decision Aid on healthcare personnel's influenza immunization decision: a randomized trial. J. Hosp. Infect. 2012;82:194-202.

454. Sundaresan P, Turner S, Kneebone A, Pearse M, Butow P. Evaluating the utility of a patient decision aid for potential participants of a prostate cancer trial (RAVES-TROG 08.03). Radiother. Oncol. 2011;101:521-4.

455. Tan J, Wolfe B. A patient decision aid for psoriasis based on current clinical practice guidelines. Arch. Dermatol. 2012;148:718-23. 
456. Tan J, Wolfe B. Improved decisional conflict and preparedness for decision making using a patient decision aid for treatment selection in psoriasis: a pilot study. Journal of cutaneous medicine and surgery. 2014;18:114-8.

457. Taylor KL, Davis JL 3rd, Turner RO, Johnson L, Schwartz MD, Kerner JF, et al. Educating African American men about the prostate cancer screening dilemma: a randomized intervention. Cancer Epidemiol. Biomarkers Prev. 2006;15:2179-88.

458. Dorfman CS, Williams RM, Kassan EC, Red SN, Dawson DL, Tuong W, et al. The development of a web- and a print-based decision aid for prostate cancer screening. BMC Med. Inform. Decis. Mak. 2010;10:12.

459. Kassan EC, Williams RM, Kelly SP, Barry SA, Penek S, Fishman MB, et al. Men's use of an Internet-based decision aid for prostate cancer screening. J. Health Commun. 2012;17:67797.

460. Williams RM, Davis KM, Luta G, Edmond SN, Dorfman CS, Schwartz MD, et al. Fostering informed decisions: a randomized controlled trial assessing the impact of a decision aid among men registered to undergo mass screening for prostate cancer. Patient Educ. Couns. 2013;91:329-36.

461. Taylor KL, Williams RM, Davis K, Luta G, Penek S, Barry S, et al. Decision making in prostate cancer screening using decision aids vs usual care: a randomized clinical trial. JAMA Intern. Med. 2013;173:1704-12.

462. Thomas KL, Zimmer LO, Dai D, Al-Khatib SM, Allen LaPointe NM, Peterson ED. Educational videos to reduce racial disparities in ICD therapy via innovative designs (VIVID): a randomized clinical trial. Am. Heart J. 2013;166:157-63.

463. Thomson R, Robinson A, Greenaway J, Lowe P, DARTS Team. Development and description of a decision analysis based decision support tool for stroke prevention in atrial fibrillation. Qual. Saf. Health Care. 2002;11:25-31.

464. Kaner E, Heaven B, Rapley T, Murtagh M, Graham R, Thomson R, et al. Medical communication and technology: a video-based process study of the use of decision aids in primary care consultations. BMC Med. Inform. Decis. Mak. 2007;7:2.

465. Thomson RG, Eccles MP, Steen IN, Greenaway J, Stobbart L, Murtagh MJ, et al. A patient decision aid to support shared decision-making on anti-thrombotic treatment of patients with atrial fibrillation: randomised controlled trial. Qual. Saf. Health Care. 2007;16:216-23.

466. Tiller K, Meiser B, Reeson E, Tucker M, Andrews L, Gaff C, et al. A decision aid for women at increased risk for ovarian cancer. Int. J. Gynecol. Cancer. 2003;13:15-22.

467. Tiller K, Meiser B, Gaff C, Kirk J, Dudding T, Phillips K-A, et al. A randomized controlled trial of a decision aid for women at increased risk of ovarian cancer. Med. Decis. Making. 2006;26:360-72.

468. Tracy CS, Dantas GC, Upshur REG. Feasibility of a patient decision aid regarding disclosure of personal health information: qualitative evaluation of the Health Care Information Directive. BMC Med. Inform. Decis. Mak. 2004;4:13. 
469. van der Krieke L, Emerencia AC, Aiello M, Sytema S. Usability evaluation of a web-based support system for people with a schizophrenia diagnosis. J. Med. Internet Res. 2012;14:e24.

470. van Peperstraten AM, Hermens RPMG, Nelen WLDM, Stalmeier PFM, Wetzels AMM, Maas PHM, et al. Deciding how many embryos to transfer after in vitro fertilisation:

Development and pilot test of a decision aid. Patient Educ. Couns. 2010;78:124-9.

471. van Peperstraten A, Nelen W, Grol R, Zielhuis G, Adang E, Stalmeier P, et al. The effect of a multifaceted empowerment strategy on decision making about the number of embryos transferred in in vitro fertilisation: randomised controlled trial. BMJ. 2010;341:c2501.

472. van Roosmalen MS, Stalmeier PFM, Verhoef LCG, Hoekstra-Weebers JEHM, Oosterwijk $\mathrm{JC}$, Hoogerbrugge N, et al. Randomized trial of a shared decision-making intervention consisting of trade-offs and individualized treatment information for BRCA1/2 mutation carriers. J. Clin. Oncol. 2004;22:3293-301.

473. van Roosmalen MS, Stalmeier PFM, Verhoef LCG, Hoekstra-Weebers JEHM, Oosterwijk $\mathrm{JC}$, Hoogerbrugge $\mathrm{N}$, et al. Randomised trial of a decision aid and its timing for women being tested for a BRCA1/2 mutation. Br. J. Cancer. 2004;90:333-42.

474. van Steenkiste B, van der Weijden TM, Stoffers JHEH, Grol RPTM. Patients' responsiveness to a decision support tool for primary prevention of cardiovascular diseases in primary care. Patient Educ. Couns. 2008;72:63-70.

475. van Til JA, Drossaert CHC, Renzenbrink GJ, Snoek GJ, Dijkstra E, Stiggelbout AM, et al. Feasibility of web-based decision aids in neurological patients. J. Telemed. Telecare. 2010;16:48-52.

476. van Tol-Geerdink JJ, Stalmeier PFM, van Lin ENJT, Schimmel EC, Huizenga $H$, van Daal WAJ, et al. Do prostate cancer patients want to choose their own radiation treatment? Int. J. Radiation Oncology Biol. Phys. 2006;66:1105-11.

477. van Tol-Geerdink JJ, Leer JW, van Lin ENJT, Schimmel EC, Huizenga H, van Daal WAJ, et al. Offering a Treatment Choice in the Irradiation of Prostate Cancer Leads to Better Informed and More Active Patients, Without Harm to Well-Being. Int. J. Radiation Oncology Biol. Phys. 2008;70:442-8.

478. van Tol-Geerdink JJ, Willem Leer J, Weijerman PC, van Oort IM, Vergunst $H$, van Lin EN, et al. Choice between prostatectomy and radiotherapy when men are eligible for both: a randomized controlled trial of usual care vs decision aid. BJU Int. 2013;111:564-73.

479. van Vugt HA, Roobol MJ, Venderbos LDF, Joosten-van Zwanenburg E, Essink-Bot M-L, Steyerberg EW, et al. Informed decision making on PSA testing for the detection of prostate cancer: an evaluation of a leaflet with risk indicator. Eur. J. Cancer. 2010;46:669-77.

480. Vandemheen KL, O'Connor A, Bell SC, Freitag A, Bye P, Jeanneret A, et al. Randomized trial of a decision aid for patients with cystic fibrosis considering lung transplantation. Am. J. Respir. Crit. Care Med. 2009;180:761-8.

481. Vandemheen KL, Aaron SD, Poirier C, Tullis E, O'Connor A. Development of a decision aid for adult cystic fibrosis patients considering referral for lung transplantation. Prog. 
Transplant. pit.sagepub.com; 2010;20:81-7.

482. Vernon SW, Bartholomew LK, McQueen A, Bettencourt JL, Greisinger A, Coan SP, et al. A randomized controlled trial of a tailored interactive computer-delivered intervention to promote colorectal cancer screening: sometimes more is just the same. Ann. Behav. Med. 2011;41:28499.

483. Veroff DR, Sullivan LA, Shoptaw EJ, Venator B, Ochoa-Arvelo T, Baxter JR, et al. Improving self-care for heart failure for seniors: the impact of video and written education and decision aids. Popul. Health Manag. online.liebertpub.com; 2012;15:37-45.

484. Vodermaier A, Caspari C, Koehm J, Kahlert S, Ditsch N, Untch M. Contextual factors in shared decision making: a randomised controlled trial in women with a strong suspicion of breast cancer. Br. J. Cancer. 2009;100:590-7.

485. Vodermaier A, Caspari C, Wang L, Koehm J, Ditsch N, Untch M. How and for whom are decision aids effective? Long-term psychological outcome of a randomized controlled trial in women with newly diagnosed breast cancer. Health Psychol. 2011;30:12-9.

486. Vogel RI, Petzel SV, Cragg J, McClellan M, Chan D, Dickson E, et al. Development and pilot of an advance care planning website for women with ovarian cancer: a randomized controlled trial. Gynecol. Oncol. 2013;131:430-6.

487. Volandes AE, Mitchell SL, Gillick MR, Chang Y, Paasche-Orlow MK. Using video images to improve the accuracy of surrogate decision-making: a randomized controlled trial. J. Am. Med. Dir. Assoc. 2009;10:575-80.

488. Volandes AE, Paasche-Orlow MK, Barry MJ, Gillick MR, Minaker KL, Chang Y, et al. Video decision support tool for advance care planning in dementia: randomised controlled trial. BMJ. 2009;338:b2159.

489. Volandes AE, Barry MJ, Chang Y, Paasche-Orlow MK. Improving decision making at the end of life with video images. Med. Decis. Making. 2010;30:29-34.

490. Volk RJ, Cass AR, Spann SJ. A randomized controlled trial of shared decision making for prostate cancer screening. Arch. Fam. Med. 1999;8:333-40.

491. Volk RJ, Spann SJ, Cass AR, Hawley ST. Patient education for informed decision making about prostate cancer screening: a randomized controlled trial with 1-year follow-up. Ann. Fam. Med. 2003;1:22-8.

492. Volk RJ, Jibaja-Weiss ML, Hawley ST, Kneuper S, Spann SJ, Miles BJ, et al. Entertainment education for prostate cancer screening: a randomized trial among primary care patients with low health literacy. Patient Educ. Couns. 2008;73:482-9.

493. Volk RJ, Linder SK, Leal VB, Rabius V, Cinciripini PM, Kamath GR, et al. Feasibility of a patient decision aid about lung cancer screening with low-dose computed tomography. Prev. Med. 2014;62:60-3.

494. Vuorma S, Rissanen P, Aalto A-M, Hurskainen R, Kujansuu E, Teperi J. Impact of patient information booklet on treatment decision--a randomized trial among women with heavy 
menstruation. Health Expect. 2003;6:290-7.

495. Vuorma S, Teperi J, Aalto A-M, Hurskainen R, Kujansuu E, Rissanen P. A randomized trial among women with heavy menstruation -- impact of a decision aid on treatment outcomes and costs. Health Expect. 2004;7:327-37.

496. Wakefield CE, Meiser B, Homewood J, Peate M, Kirk J, Warner B, et al. Development and pilot testing of two decision aids for individuals considering genetic testing for cancer risk. J. Genet. Couns. 2007;16:325-39.

497. Wakefield CE, Meiser B, Homewood J, Taylor A, Gleeson M, Williams R, et al. A randomized trial of a breast/ovarian cancer genetic testing decision aid used as a communication aid during genetic counseling. Psychooncology. 2008;17:844-54.

498. Wakefield CE, Meiser B, Homewood J, Peate M, Taylor A, Lobb E, et al. A randomized controlled trial of a decision aid for women considering genetic testing for breast and ovarian cancer risk. Breast Cancer Res. Treat. 2008;107:289-301.

499. Wakefield CE, Meiser B, Homewood J, Ward R, O’Donnell S, Kirk J, et al. Randomized trial of a decision aid for individuals considering genetic testing for hereditary nonpolyposis colorectal cancer risk. Cancer. 2008;113:956-65.

500. Wakefield CE, Watts KJ, Meiser B, Sansom-Daly U, Barratt A, Mann GJ, et al. Development and pilot testing of an online screening decision aid for men with a family history of prostate cancer. Patient Educ. Couns. 2011;83:64-72.

501. Watts KJ, Meiser B, Wakefield CE, Barratt AL, Howard K, Cheah BC, et al. Online prostate cancer screening decision aid for at-risk men: a randomized trial. Health Psychol. 2014;33:98697.

502. Wall EM. Development of a decision aid for women choosing a method of birth control. J. Fam. Pract. psycnet.apa.org; 1985;21:351-5.

503. Wang C, Gonzalez R, Milliron KJ, Strecher VJ, Merajver SD. Genetic counseling for BRCA1/2: a randomized controlled trial of two strategies to facilitate the education and counseling process. Am. J. Med. Genet. A. 2005;134A:66-73.

504. Watson E, Hewitson P, Brett J, Bukach C, Evans R, Edwards A, et al. Informed decision making and prostate specific antigen (PSA) testing for prostate cancer: a randomised controlled trial exploring the impact of a brief patient decision aid on men's knowledge, attitudes and intention to be tested. Patient Educ. Couns. 2006;63:367-79.

505. Weinrich SP, Seger RE, Rao GS, Chan EC, Hamm RM, Godley PA, et al. A decision aid for teaching limitations of prostate cancer screening. J. Natl. Black Nurses Assoc.

academia.edu; 2008;19:1-11.

506. Weng HH, Kaplan RM, Boscardin WJ, Maclean CH, Lee IY, Chen W, et al. Development of a decision aid to address racial disparities in utilization of knee replacement surgery. Arthritis Rheum. 2007;57:568-75.

507. Westreich L, Levine S, Ginsburg P, Wilets I. Patient knowledge about electroconvulsive 
therapy: effect of an informational video. Convuls. Ther. journals.Iww.com; 1995;11:32-7.

508. Weyand SA, Frize M, Bariciak E, Dunn S. Development and usability testing of a parent decision support tool for the neonatal intensive care unit. Conf. Proc. IEEE Eng. Med. Biol. Soc. 2011;2011:6430-3.

509. Whelan TJ, Levine MN, Gafni A, Lukka H, Mohide EA, Patel M, et al. Breast irradiation postlumpectomy: development and evaluation of a decision instrument. J. Clin. Oncol. 1995;13:847-53.

510. Whelan T, Levine M, Gafni A, Sanders K, Willan A, Mirsky D, et al. Mastectomy or lumpectomy? Helping women make informed choices. J. Clin. Oncol. 1999;17:1727-35.

511. Whelan T, Sawka C, Levine M, Gafni A, Reyno L, Willan A, et al. Helping patients make informed choices: a randomized trial of a decision aid for adjuvant chemotherapy in lymph nodenegative breast cancer. J. Natl. Cancer Inst. 2003;95:581-7.

512. Whelan T, Levine M, Willan A, Gafni A, Sanders K, Mirsky D, et al. Effect of a decision aid on knowledge and treatment decision making for breast cancer surgery: a randomized trial. JAMA. 2004;292:435-41.

513. Whiskey E, Taylor D. Evaluation of an antipsychotic information sheet for patients. Int. J. Psychiatry Clin. Pract. 2005;9:264-70.

514. Wilkins EG, Lowery JC, Copeland LA, Goldfarb SL, Wren PA, Janz NK. Impact of an educational video on patient decision making in early breast cancer treatment. Med. Decis. Making. 2006;26:589-98.

515. Willemsen MC, Wiebing $M$, van Emst $A$, Zeeman $G$. Helping smokers to decide on the use of efficacious smoking cessation methods: a randomized controlled trial of a decision aid. Blackwell Science, Ltd Oxford, UK ADDAddiction. 2006;0965:2140.

516. Wilson ME, Krupa A, Hinds RF, Litell JM, Swetz KM, Akhoundi A, et al. A video to improve patient and surrogate understanding of cardiopulmonary resuscitation choices in the ICU: a randomized controlled trial. Crit. Care Med. 2015;43:621-9.

517. Wilt TJ, Paul J, Murdoch M, Nelson D, Nugent S, Rubins HB. Educating men about prostate cancer screening. A randomized trial of a mailed pamphlet. Eff. Clin. Pract. 2000;4:112-20.

518. Wolf AMD, Schorling JB. Does Informed Consent Alter Elderly Patients' Preferences for Colorectal Cancer Screening? Journal of General Internal Medicine. 2000;15:24-30.

519. Wolf AM, Nasser JF, Wolf AM, Schorling JB. The impact of informed consent on patient interest in prostate-specific antigen screening. Arch. Intern. Med. jamanetwork.com; 1996;156:1333-6.

520. Wolf AM, Schorling JB. Preferences of elderly men for prostate-specific antigen screening and the impact of informed consent. J. Gerontol. A Biol. Sci. Med. Sci. 1998;53:M195-200.

521. Woltmann EM, Wilkniss SM, Teachout A, McHugo GJ, Drake RE. Trial of an electronic 
decision support system to facilitate shared decision making in community mental health. Psychiatr. Serv. Am Psychiatric Assoc; 2011;62:54-60.

522. Wong SSM, Thornton JG, Gbolade B, Bekker HL. A randomised controlled trial of a decision-aid leaflet to facilitate women's choice between pregnancy termination methods. BJOG. 2006;113:688-94.

523. Wong J, D'Alimonte L, Angus J, Paszat L, Metcalfe K, Whelan T, et al. Development of Patients' Decision Aid for Older Women With Stage I Breast Cancer Considering Radiotherapy After Lumpectomy. Int. J. Radiat. Oncol. Biol. Phys. Elsevier; 2012;84:30-8.

524. Wright $P$, John $C$, Belt $S$. Designing an interactive decision explorer. Information Design Journal. John Benjamins; 2002;11:252-60.

525. Wright $P$, Belt $S$, John $C$. Helping people assess the health risks from lifestyle choices: comparing a computer decision aid with customized printed alternative. Commun. Med. 2004;1:183-92.

526. Wroe AL, Turner N, Owens RG. Evaluation of a decision-making aid for parents regarding childhood immunizations. Health Psychol. 2005;24:539-47.

527. Yun YH, Lee MK, Park S, Lee JL, Park J, Choi YS, et al. Use of a decision aid to help caregivers discuss terminal disease status with a family member with cancer: a randomized controlled trial. J. Clin. Oncol. 2011;29:4811-9.

528. Zapka JG, Lemon SC, Puleo E, Estabrook B, Luckmann R, Erban S. Patient education for colon cancer screening: a randomized trial of a video mailed before a physical examination. Ann. Intern. Med. 2004;141:683-92.

529. Zeliadt SB, Hannon PA, Trivedi RB, Bonner LM, Vu TT, Simons C, et al. A preliminary exploration of the feasibility of offering men information about potential prostate cancer treatment options before they know their biopsy results. BMC Med. Inform. Decis. Mak. 2013;13:19.

530. Adamo-Villani N. A Virtual Learning Environment for Deaf Children: Design and Evaluation. International Journal of Human and Social Sciences. 2007;2:123-8.

531. Ahlers-Schmidt CR, Hart T, Chesser A, Paschal A, Nguyen T, Wittler RR. Content of text messaging immunization reminders: what low-income parents want to know. Patient education and counseling. 2011;85:119-21.

532. Hart T, Ahlers-Schmidt CR, Chesser A, Jones J, Williams KS, Wittler RR. Physician impressions of using text message technology to increase vaccination compliance. Telemed. J. E. Health. 2011;17:427-30.

533. Ahlers-Schmidt CR, Chesser AK, Paschal AM, Hart TA, Williams KS, Yaghmai B, et al. Parent opinions about use of text messaging for immunization reminders. Journal of medical Internet research. 2012;14:e83.

534. Ahlers-Schmidt CR, Hart T, Chesser A, Williams KS, Yaghmai B, Shah-Haque S, et al. Using Human Factors Techniques to Design Text Message Reminders for Childhood 
Immunization. Health Education \& Behavior. 2012;39:538-43.

535. Ahlers-Schmidt CR, Chesser AK, Nguyen T, Brannon J, Hart TA, Williams KS, et al. Feasibility of a randomized controlled trial to evaluate Text Reminders for Immunization Compliance in Kids (TRICKs). Vaccine. 2012;30:5305-9.

536. Ahlers-Schmidt CR, Chesser A, Brannon J, Lopez V, Shah-Haque S, Williams K, et al. "Necesita una vacuna": what Spanish-speakers want in text-message immunization reminders. Journal of health care for the poor and underserved. 2013;24:1031-41.

537. Al-Abdullatif A, Al-Negheimish H, Al-Mofeez L, Al-Khalifa N, Al-Andas L, Al-Wabil A. Mindcontrolled augmentative and alternative communication for people with severe motor disabilities. In: IEEE, editor. 2013 9th International Conference on Innovations in Information Technology (IIT). 2013. p. 107-12.

538. Amiri M, Dezfooli MS, Mortezaei SR. Designing an ergonomics backpack for student aged 7-9 with user centred design approach. Work. 2012;41:1193-201.

539. Atkinson NL, Billing AS, Desmond SM, Gold RS, Tournas-Hardt A. Assessment of the nutrition and physical activity education needs of low-income, rural mothers: can technology play a role? J. Community Health. 2007;32:245-67.

540. Atkinson NL, Saperstein SL, Desmond SM, Gold RS, Billing AS, Tian J. Rural eHealth nutrition education for limited-income families: an iterative and user-centered design approach. J. Med. Internet Res. 2009;11:e21.

541. Atkinson NL, Desmond SM, Saperstein SL, Billing AS, Gold RS, Tournas-Hardt A. Assets, challenges, and the potential of technology for nutrition education in rural communities. J. Nutr. Educ. Behav. 2010;42:410-6.

542. Bae J, Wolpin S, Kim E, Lee S, Yoon S, An K. Development of a user-centered health information service system for depressive symptom management. Nurs. Health Sci.

2009;11:185-93.

543. Cafazzo JA, Casselman M, Hamming N, Katzman DK, Palmert MR. Design of an mHealth app for the self-management of adolescent type 1 diabetes: a pilot study. J. Med. Internet Res. 2012;14:e70.

544. Carey-Smith BE, Evans NM, Orpwood RD. A user-centred design process to develop technology to improve sleep quality in residential care homes. Technol. Disabil. 2013;25:49-58.

545. Cavallo F, Aquilano M, Bonaccorsi M, Limosani R, Manzi A, Carrozza MC, et al. On the design, development and experimentation of the ASTRO assistive robot integrated in smart environments. 2013 IEEE International Conference on Robotics and Automation [Internet]. 2013. Available from: http://dx.doi.org/10.1109/icra.2013.6631187

546. Civan A, Pratt W. Threading together patient expertise. AMIA Annu. Symp. Proc. 2007;140-4.

547. Civan-Hartzler A, McDonald DW, Powell C, Skeels MM, Mukai M, Pratt W. Bringing the Field into Focus: User-centered Design of a Patient Expertise Locator. Proc SIGCHI Conf Hum 
Factor Comput Syst. 2010;2010:1675-84.

548. Dabbs ADV, Myers BA, Mc Curry KR, Dunbar-Jacob J, Hawkins RP, Begey A, et al. Usercentered design and interactive health technologies for patients. Comput. Inform. Nurs.

2009;27:175-83.

549. Das A, Svanæs D. Human-centred methods in the design of an e-health solution for patients undergoing weight loss treatment. Int. J. Med. Inform. 2013;82:1075-91.

550. Faraji A, Farahmand MR. An Ergonomic Computer Mouse for Professional Designers. Applied Mechanics and Materials. Trans Tech Publ; 2014. p. 194-8.

551. Felice M, Di Mascio T, Gennari R. A Visual Ontology-Driven Interface for a Web Sign Language Dictionary. Lecture Notes in Computer Science. 2007. p. 429-40.

552. Fico G, Fioravanti A, Arredondo MT, Ardigó D, Guillén A. A healthy lifestyle coachingpersuasive application for patients with type 2 diabetes. Conf. Proc. IEEE Eng. Med. Biol. Soc. 2010;2010:2221-4.

553. Gilliam ML, Martins SL, Bartlett E, Mistretta SQ, Holl JL. Development and testing of an iOS waiting room "app" for contraceptive counseling in a Title X family planning clinic. Am. J. Obstet. Gynecol. Elsevier; 2014;211:481.e1-481.e8.

554. Harada S, Wobbrock JO, Landay JA. VoiceDraw: A Hands-Free Voice-Driven Drawing Application for People with Motor Impairments. Proceedings of the 9th international ACM SIGACCESS conference on Computers and accessibility. ACM; 2007. p. 27-34.

555. Herschman J, Kasenberg T, Levy D, Ruth N, Taberner C, Kaufman M, et al. Development of a smartphone app for adolescents with lupus: a collaborative meeting-based methodology inclusive of a wide range of stakeholders. Rev. Panam. Salud Publica. 2014;35:471-6.

556. Izard J, Hartzler A, Avery DI, Shih C, Dalkin BL, Gore JL. User-centered design of quality of life reports for clinical care of patients with prostate cancer. Surgery. 2014;155:789-96.

557. Hartzler AL, Izard JP, Dalkin BL, Mikles SP, Gore JL. Design and feasibility of integrating personalized PRO dashboards into prostate cancer care. J. Am. Med. Inform. Assoc. 2016;23:38-47.

558. Jia G, Zhou J, Yang P, Lin C, Cao X, Hu H, et al. Integration of user centered design in the development of health monitoring system for elderly. Engineering in Medicine and Biology Society (EMBC), 2013 35th Annual International Conference of the IEEE. IEEE; 2013. p. 174851.

559. Johnston SK, Nguyen RNHQ, Wolpin RNS. Designing and Testing a Web-Based Interface for Self-monitoring of Exercise and Symptoms for Older Adults With Chronic Obstructive Pulmonary Disease. CIN: Computers, Informatics, Nursing. 2009;27:166-74.

560. Lalji Z, Good J. Designing new technologies for illiterate populations: A study in mobile phone interface design. Interact. Comput. Elsevier B.V.; 2008;20:574-86.

561. Lepicard G, Vella F, Vigouroux N, Rigolleau B, Chautard D, Pucheu E. The Virtual Paddle: 
An Universal Interaction for Accessible Video Games. Universal Access in Human-Computer Interaction. Applications and Services. Springer, Berlin, Heidelberg; 2007. p. 677-86.

562. Lepicard G, Vigouroux N, Vella F. Accessibility Interface for Video Games. In: Eizmendi G, Azkoitia JM, Craddock GM, editors. Challenges for assistive technology: AAATE 07. los Press; 2007. p. 850-9.

563. Lewis J, Brown DJ, Powell HM. Development of a virtual environment to teach independent travel skills to people with a learning disability. Simulation in Industry'2000. 2000;385-9.

564. Shopland N, Lewis J, Brown DJ, Dattani-Pitt K. Design and evaluation of a flexible travel training environment for use in a supported employment setting. International Journal on Disability and Human Development. 2005;4:251-8.

565. Limbach T. Supporting Dementia Patients at Home: The MeMoTray. Biomed. Tech. [Internet]. 2012;57. Available from: http://www.degruyter.com/view/j/bmte.2012.57.issue-s1K/bmt-2012-4423/bmt-2012-4423.xml

566. Ma M-Y, Wu F-G, Chang R-H. A new design approach of user-centered design on a personal assistive bathing device for hemiplegia. Disabil. Rehabil. 2007;29:1077-89.

567. MacCallum L, McGaw H, Meshkat N, Valentinis A, Beard Ashley L, Bhatia S, et al. Use of an interdisciplinary, participatory design approach to develop a usable patient self-assessment tool in atrial fibrillation. PPAR Res. 2013;1139.

568. Marcu G, Bardram J, Gabrielli S. A Framework for Overcoming Challenges in Designing Persuasive Monitoring and Feedback Systems for Mental Illness. 2011 5th International Conference on Pervasive Computing Technologies for Healthcare (PervasiveHealth). IEEE; 2012. p. 1-8.

569. Markopoulos P, Timmermans AAA, Beursgens L, van Donselaar R, Seelen HAM. Us'em: the user-centered design of a device for motivating stroke patients to use their impaired armhand in daily life activities. Engineering in Medicine and Biology Society, EMBC, 2011 Annual International Conference of the IEEE. IEEE; 2011. p. 5182-7.

570. Marti P, Giusti L. A robot companion for inclusive games: A user-centred design perspective. 2010 IEEE International Conference on Robotics and Automation. ieeexplore.ieee.org; 2010. p. 4348-53.

571. Massoudi BL, Olmsted MG, Zhang Y, Carpenter RA, Barlow CE, Huber R. A web-based intervention to support increased physical activity among at-risk adults. J. Biomed. Inform. 2010;43:S41-5.

572. Olmsted MG, Massoudi BL, Zhang Y. What consumers want in personal health applications: findings from Project HealthDesign. Pers. Ubiquit. Comput. Springer London; 2015;19:79-83.

573. Mawson S, Nasr N, Parker J, Zheng H, Davies R, Mountain G. Developing a personalised self-management system for post stroke rehabilitation; utilising a user-centred design methodology. Disabil. Rehabil. Assist. Technol. 2014;9:521-8. 
574. Parker J, Mawson S, Mountain G, Nasr N, Davies R, Zheng H. The provision of feedback through computer-based technology to promote self-managed post-stroke rehabilitation in the home. Disabil. Rehabil. Assist. Technol. 2014;9:529-38.

575. McGaffey A, Hughes K, Fidler SK, D’Amico FJ, Stalter MN. Can Elvis Pretzley and the Fitwits improve knowledge of obesity, nutrition, exercise, and portions in fifth graders? Int. J. Obes. 2010;34:1134-42.

576. Munoz R, Barcelos T, Noel R, Kreisel S. Development of Software that Supports the Improvement of the Empathy in Children with Autism Spectrum Disorder. 2012 31st International Conference of the Chilean Computer Science Society [Internet]. 2012. Available from: http://dx.doi.org/10.1109/sccc.2012.33

577. Nasir MHNM, Hassan NH, Nor MKM. Participatory User Centered Design Techniques for a Web Information System for Stroke. 2008 International Symposium on Communications and Information Technologies. ieeexplore.ieee.org; 2008. p. 557-62.

578. Neale H, Cobb S, Wilson J. A front ended approach to the user-centred design of VEs. Proceedings IEEE Virtual Reality 2002. IEEE; 2002. p. 191-8.

579. Osborn CY, Mulvaney SA. Development and Feasibility of a Text Messaging and Interactive Voice Response Intervention for Low-Income, Diverse Adults with Type 2 Diabetes Mellitus. Journal of Diabetes Science and Technology. 2013;7:612-22.

580. Peters J-P, Thillou C, Ferreira S. Embedded Reading Device for Blind People: A UserCentred Design. International Symposium on Information Theory ISIT 2004 Proceedings. IEEE; 2004. p. 217-22.

581. Mancas-Thillou C, Ferreira S, Demeyer J, Minetti C, Gosselin B. A Multifunctional Reading Assistant for the Visually Impaired. Journal on Image and Video Processing. Springer International Publishing; 2007;2007:1-11.

582. Petrie H, Johnson V, Strothotte T, Michel R, Raab A, Reichert L. User-centred design in the development of a navigational aid for blind travellers. In: Howard S, Hammond J, Lindgaard G, editors. Human-Computer Interaction INTERACT '97. Springer US; 1997. p. 220-7.

583. Pigini L, Facal D, Blasi L, Andrich R. Service robots in elderly care at home: Users' needs and perceptions as a basis for concept development. Technol. Disabil. 2012;24:303-11.

584. Rizzo A, Newman B, Parsons T, Reger G, Holloway K, Gahm G, et al. Development and Clinical Results from the Virtual Iraq Exposure Therapy Application for PTSD. 2009 Virtual Rehabilitation International Conference [Internet]. 2009. Available from: http://dx.doi.org/10.1109/icvr.2009.5174198

585. Rizzo AS, Difede J, Rothbaum BO, Reger G, Spitalnick J, Cukor J, et al. Development and early evaluation of the Virtual Iraq/Afghanistan exposure therapy system for combat-related PTSD. Ann. N. Y. Acad. Sci. 2010;1208:114-25.

586. Robinson L, Brittain K, Lindsay S, Jackson D, Olivier P. Keeping In Touch Everyday (KITE) project: developing assistive technologies with people with dementia and their carers to promote independence. Int. Psychogeriatr. 2009;21:494-502. 
587. Sanchez JH, Flores HE. Audio concepts maps for virtual rehabilitation of the blind. 2008 Virtual Rehabilitation [Internet]. 2008. Available from:

http://dx.doi.org/10.1109/icvr.2008.4625158

588. Sánchez-Morillo D, Crespo M, León A, Crespo Foix LF. A novel multimodal tool for telemonitoring patients with COPD. Inform. Health Soc. Care. 2015;40:1-22.

589. Sanchez-Morillo D, Fernandez-Granero MA, Jiménez AL. Detecting COPD exacerbations early using daily telemonitoring of symptoms and k-means clustering: a pilot study. Med. Biol. Eng. Comput. Springer Berlin Heidelberg; 2015;53:441-51.

590. Siek KA, Connelly KH, Rogers Y. Pride and prejudice: learning how chronically ill people think about food. Proceedings of the SIGCHI Conference on Human Factors in Computing Systems. ACM; 2006. p. 947-50.

591. Connelly K, Siek KA, Chaudry B, Jones J, Astroth K, Welch JL. An offline mobile nutrition monitoring intervention for varying-literacy patients receiving hemodialysis: a pilot study examining usage and usability. J. Am. Med. Inform. Assoc. 2012;19:705-12.

592. Slagle JM, Gordon JS, Harris CE, Davison CL, Culpepper DK, Scott P, et al. MyMediHealth - Designing a next generation system for child-centered medication management. J. Biomed. Inform. 2010;43:S27-31.

593. Stinson JN, Lalloo C, Harris L, Isaac L, Campbell F, Brown S, et al. iCanCope with Pain ${ }^{\mathrm{TM}}$ : User-centred design of a web- and mobile-based self-management program for youth with chronic pain based on identified health care needs. Pain Res. Manag. 2014;19:257-65.

594. Taylor DP, Bray BE, Staggers N, Olson RJ. User-centered development of a Web-based preschool vision screening tool. AMIA Annu. Symp. Proc. 2003;654-8.

595. van der Weegen S, Verwey R, Spreeuwenberg M, Tange $H$, van der Weijden $T$, de Witte $L$. The development of a mobile monitoring and feedback tool to stimulate physical activity of people with a chronic disease in primary care: a user-centered design. JMIR Mhealth Uhealth. 2013;1:e8.

596. Verwey R, van der Weegen S, Spreeuwenberg M, Tange $H$, van der Weijden $T$, de Witte $L$. Technology combined with a counseling protocol to stimulate physical activity of chronically ill patients in primary care. Stud. Health Technol. Inform. 2014;201:264-70.

597. Verdezoto N, Grönvall E. Designing a Tablet Touch-Screen Interface for Older Adults. How to Design Touch Interfaces for and with Older Adults: Identification of Challenges and Opportunities. 2012.

598. Verdezoto NX, Wolff Olsen J. Personalized Medication Management: Towards a Design of Individualized Support for Elderly Citizens at Home. Proceedings of the 2Nd ACM SIGHIT International Health Informatics Symposium. New York, NY, USA: ACM; 2012. p. 813-8.

599. Dalgaard LG, Grönvall E, Verdezoto N. MediFrame: A Tablet Application to Plan, Inform, Remind and Sustain Older Adults' Medication Intake. 2013 IEEE International Conference on Healthcare Informatics. 2013. p. 36-45. 
600. Verhoeven F, v. Gemert-Pijnen L, Hendrix R. User-Centered Development of Effective Web-Based Patient Education: A Case Study about Methicillin-Resistant Staphylococcus aureus. 2010 Second International Conference on eHealth, Telemedicine, and Social Medicine. 2010. p. 39-44.

601. Vermeulen J, Neyens JC, Spreeuwenberg MD, van Rossum E, Sipers W, Habets H, et al. User-centered development and testing of a monitoring system that provides feedback regarding physical functioning to elderly people. Patient Prefer. Adherence. 2013;7:843-54.

602. Walji MF, Zhang J. Human-Centered Design of Persuasive Appointment Reminders. Proceedings of the 41st Annual Hawaii International Conference on System Sciences (HICSS 2008) [Internet]. 2008. Available from: http://dx.doi.org/10.1109/hicss.2008.194

603. Wentz E, Nydén A, Krevers B. Development of an internet-based support and coaching model for adolescents and young adults with ADHD and autism spectrum disorders: a pilot study. Eur. Child Adolesc. Psychiatry. 2012;21:611-22.

604. Wolpin SE, Halpenny B, Whitman G, McReynolds J, Stewart M, Lober WB, et al. Development and usability testing of a web-based cancer symptom and quality-of-life support intervention. Health Informatics J. 2015;21:10-23.

605. Wu F-G, Ma M-Y, Chang R-H. A new user-centered design approach: a hair washing assistive device design for users with shoulder mobility restriction. Appl. Ergon. 2009;40:87886.

606. Yu CH, Parsons JA, Hall S, Newton D, Jovicic A, Lottridge D, et al. User-centered design of a web-based self-management site for individuals with type 2 diabetes - providing a sense of control and community. BMC Med. Inform. Decis. Mak. 2014;14:60.

607. Yu CH, Parsons JA, Mamdani M, Lebovic G, Hall S, Newton D, et al. A web-based intervention to support self-management of patients with type 2 diabetes mellitus: effect on selfefficacy, self-care and diabetes distress. BMC Med. Inform. Decis. Mak. 2014;14:117.

608. Zhang D, Hariz M, Mokhtari M. Assisting Elders with Mild Dementia Staying at Home. 2008 Sixth Annual IEEE International Conference on Pervasive Computing and Communications (PerCom). 2008. p. 692-7.

609. Höhne J, Holz E, Staiger-Sälzer P, Müller K-R, Kübler A, Tangermann M. Motor imagery for severely motor-impaired patients: evidence for brain-computer interfacing as superior control solution. PLoS One. 2014;9:e104854.

610. Botrel L, Holz EM, Kübler A. Brain Painting V2: evaluation of P300-based brain-computer interface for creative expression by an end-user following the user-centered design. BrainComputer Interfaces. 2015;2:135-49. 


\title{
Appendix 1. Search strategy
}

\author{
Applying Methods of User-Centered Design to Achieve Patient- \\ Centered Care \\ Prepared by: William Witteman, MLIS
}

\section{Literature Search Methodology}

The goal of this literature search is to obtain all references describing tools of any kind that aid in the making of a medical decision. These references will be assessed for indications that the users of the tools have been consulted in their creation and design. Unfortunately, while medical decision aids are not particularly new, nor are user-centered design methods novel, there is no clear, specific way to easily identify references in the scholarly literature that combine these concepts.

Due to this limitation in the indexing of the literature, a very broad, highly sensitive set of search methods was applied to ensure that no important papers or other materials describing this subject were missed.

For the medical literature, the existing Cochrane Review by Dawn Stacey et al entitled "Decision aids for people facing health treatment or screening decisions" provides a guide for finding decision aids. The search strategy in this review contains much of what is needed in the search for this project. However, because they were looking to only synthesize randomized controlled trials for screening and treatment of medical conditions, it was more restrictive than would be appropriate for this project.

With that in mind, the search strategy was slightly modified and applied to the following databases: Thompson Web of Science (all databases), PubMed (ILM), MEDLINE (Embase.com), EMBASE (Embase.com), and the Cochrane Library (Wiley). However, this search strategy along is unlikely to provide full coverage of the existing literature, especially for references published outside of the medical literature. Additionally, is was deemed essential that if a decision aid development process was described in the scholarly literature, it may not discuss in sufficient detail the medical decision, and so would be missed by this approach. To that end, addition search strategies were formulated and executed.

First, the existence of the International Patient Decision Aid Standards (IPDAS) makes it a literary keystone, very likely to be cited by any publication creating a decision aid. Therefore, we used the Thompson Web of Science (all databases) citation tools to search for all references that cite this paper.

The concept of "user centered" design was the central concept that was used to create a second broad search strategy. This approach was used to search the following databases: Thompson 
Web of Science (all databases), PubMed (ILM), MEDLINE (Ovid), EMBASE (Embase.com), the Cochrane Library (Wiley) and IEEE Xplore.

In addition, the screening process in the Stacey review was more restrictive than appropriate for this investigation, and so it had to be re-run and re-screened to ensure that RCTs which were excluded from the Cochrane review were not erroneously ignored in the context of this review. This involved running the same search conducted in the Stacey review in PsycINFO (Ovid), CINAHL (EBSCOHost), MEDLINE (Ovid), EMBASE (Embase.com), and the Cochrane Library (Wiley).

We also conducted a screen of the references of the Stacey Cochrane review, as well as each other literature review that appeared in our set of results. The procedure here was that if a paper was describing the methods or synthesising the results of studies that provided a decision aid to patients, we screened the references of that paper to ensure that any studies or other relevant materials were captured in our search.

The screening process was conducted in accordance with the standard methods for systematic reviews. After a training period where all screeners practiced on a small sub-set of the results, two screeners reviewed each title and abstract for inclusion or exclusion. If those two screeners disagreed, a third screener adjudicated the reference and determined if the reference should be included for further screening.

Once all of the references had been screened by title and abstract, the full text of the papers still thought to be of value to the review were obtained, and screened by two independent reviewers. These references where then divided into three categories; include and retain for data extraction, exclude, and retain for a screen of the references, but do not include for data extraction.

Below are the search strategies for each database searched. These strategies were peerreviewed by Marina Englesakis, MLIS or Michelle Fiander, MA MLIS.

\section{Search Strategies}

\section{Decision Aids:}

\section{Web of Science - Search Conducted 2014/05/11}

\begin{tabular}{|l|l|l|}
\hline Line Number & Search String & Article Count \\
\hline$\# 3$ & \#2 AND \#1 & 15,597 \\
\hline$\# 2$ & TOPIC: (TOPIC: ((user OR human) (centered & Approximately \\
& OR centred)) OR TOPIC: ('development' NOT & \\
& grow*) OR TOPIC: (evaluation) OR TOPIC: & \\
& ('feasibility' (test* OR stud* OR evaluat*)) OR & \\
& TOPIC: (acceptability) OR TOPIC: (pilot (test* & \\
& OR stud* OR evaluat*)) OR TOPIC: (usability) & \\
& OR TOPIC: (user (stud* OR test* OR evaluat* & \\
\hline
\end{tabular}




\begin{tabular}{|l|l|r|}
\hline \multirow{2}{*}{ \#1 } & $\begin{array}{l}\text { OR experience)) OR TOPIC: (patient* } \\
\text { (satisfact* OR opinion* OR knowledg* OR } \\
\text { outcome* OR 'decisional conflict'))) }\end{array}$ & \\
\hline & $\begin{array}{l}\text { TOPIC: (TOPIC: ((decision* OR decid*) } \\
\text { (support* OR aid* OR tool* OR material*)) OR } \\
\text { TOPIC: (decision (board* OR guide* OR } \\
\text { counsel*)) OR TOPIC: ('computer decision } \\
\text { making') OR TOPIC: ('shared decision making') } \\
\text { OR TOPIC: (informed (choice* OR decision*))) }\end{array}$ & \\
\hline
\end{tabular}

\section{Referencing IPDAS}

Three hundred and twenty-two (322) articles refer to the International Patient Decision Aid Standards (IPDAS) primary publication, according to the Web of Science reference database. The citation for the IPDAS primary publication is here:

Glyn Elwyn, Annette O'Connor, Dawn Stacey, Robert Volk, Adrian Edwards, Angela Coulter, Richard Thomson, Alexandra Barratt, Michael Barry, Steven Bernstein, Phyllis Butow, Aileen Clarke, Vikki Entwistle, Deb Feldman-Stewart, Margaret Holmes-Rovner, Hilary LlewellynThomas, Nora Moumjid, Al Mulley, Cornelia Ruland, Karen Sepucha, Alan Sykes, Tim Whelan, on behalf of the International Patient Decision Aids Standards (IPDAS) Collaboration. Developing a quality criteria framework for patient decision aids: online international Delphi consensus process. British Medical Journal. 2006 Aug 26;333(7565):417.

\section{Embase.com - MEDLINE and Embase - Search conducted 2014/05/01}

\begin{tabular}{|l|l|l|}
\hline Line Number & Search String & Article Count \\
\hline$\# 38$ & $\# 36$ AND [medline]/lim & 19,444 \\
\hline$\# 37$ & $\# 36$ AND [embase]/lim & 20,438 \\
\hline$\# 36$ & $\# 34$ OR \#35 & 27,147 \\
\hline$\# 35$ & $\# 7$ AND \#33 & 12,810 \\
\hline$\# 34$ & $\# 7$ AND \#17 & 20,865 \\
\hline$\# 33$ & $\# 18$ OR \#19 OR \#20 OR \#21 OR \#22 OR \#25 OR & $6,752,488$ \\
& $\# 26$ OR \#27 OR \#28 OR \#29 OR \#30 OR \#31 OR & \\
\hline$\# 32$ & $\# 32$ & \\
\hline$\# 31$ & cross AND sectional NEXT/2 (study OR studies) & 153,915 \\
\hline$\# 30$ & epidemiologic\$ NEXT/2 (study OR studies) & 25,015 \\
\hline$\# 29$ & observational NEXT/2 (study OR studies) & 91,674 \\
\hline$\# 28$ & 'follow up' NEXT/2 (study OR studies) & 51,565 \\
\hline$\# 27$ & 'case control' NEXT/2 (study OR studies) & 114,434 \\
\hline$\# 26$ & cohort NEXT/2 (study OR studies) & 117,425 \\
\hline$\# 25$ & 'cohort analysis'/exp & 164,730 \\
\hline$\# 24$ & $\# 23$ NOT \#24 & 243,865 \\
\hline$\# 23$ & 'randomized controlled trials'/exp & 49,809 \\
\hline$\# 22$ & 'prospective study'/exp & 245,239 \\
\hline$\# 21$ & 'retrospective study'/exp & 335,655 \\
\hline
\end{tabular}




\begin{tabular}{|c|c|c|}
\hline$\# 20$ & 'family study'/exp & 10,382 \\
\hline$\# 19$ & 'case control study' & 107,228 \\
\hline$\# 18$ & 'clinical study'/exp & $6,550,290$ \\
\hline$\# 17$ & $\begin{array}{l}\text { \#8 OR \#9 OR \#10 OR \#11 OR \#12 OR \#13 OR } \\
\# 14 \text { OR \#15 OR \#16 }\end{array}$ & $5,360,797$ \\
\hline$\# 16$ & $\begin{array}{l}\text { patient* NEAR/3 (satisfact* OR opinion* OR } \\
\text { knowledg* OR outcome* OR 'decisional } \\
\text { conflict') }\end{array}$ & 320,696 \\
\hline$\# 15$ & $\begin{array}{l}\text { user NEAR/5 (stud* OR test* OR evaluat* OR } \\
\text { experience) }\end{array}$ & 4,731 \\
\hline$\# 14$ & usability & 5,978 \\
\hline$\# 13$ & pilot NEXT/1 (test* OR stud* OR evaluat*) & 105,375 \\
\hline$\# 12$ & acceptability & 22,979 \\
\hline$\# 11$ & $\begin{array}{l}\text { 'feasibility' NEAR/5 (test* OR stud* OR } \\
\text { evaluat*) }\end{array}$ & 82,306 \\
\hline$\# 10$ & evaluat* & $3,014,903$ \\
\hline \#9 & $\begin{array}{l}\text { 'development'/exp OR 'development' NOT } \\
\text { grow* }\end{array}$ & $2,395,811$ \\
\hline \#8 & $\begin{array}{l}\text { (user OR human) NEXT/2 (centered OR } \\
\text { centred) }\end{array}$ & 887 \\
\hline$\# 7$ & \#1 OR \#2 OR \#3 OR \#4 OR \#5 OR \#6 & 46,996 \\
\hline$\# 6$ & informed NEAR/2 (choice* OR decision*) & 8,121 \\
\hline$\# 5$ & 'shared decision making' & 3,079 \\
\hline$\# 4$ & computer* NEXT/2 'decision making' & 631 \\
\hline \#3 & $\begin{array}{l}\text { 'decision-making computer assisted'/exp OR } \\
\text { 'decision-making computer assisted' }\end{array}$ & 12,338 \\
\hline$\# 2$ & $\begin{array}{l}\text { decision NEAR/3 (board* OR guide* OR } \\
\text { counsel*) }\end{array}$ & 5,375 \\
\hline$\# 1$ & $\begin{array}{l}\text { (decision* OR decid*) NEAR/4 (support* OR } \\
\text { aid* OR tool* OR material*) }\end{array}$ & 32,435 \\
\hline
\end{tabular}

Cochrane Library - Searched conducted 2014/04/30

\begin{tabular}{|l|l|l|}
\hline Line Number & Search String & Article Count \\
\hline$\# 19$ & $\# 7$ and \#18 & 5524 \\
\hline$\# 18$ & $\begin{array}{l}\# 8 \text { or \#9 or \#10 or \#11 or \#12 or \#13 or \#14 or } \\
\# 15 \text { or \#16 or \#17 }\end{array}$ & 188293 \\
\hline$\# 17$ & $\begin{array}{l}\text { patient* near/3 (satisfact* or opinion* or } \\
\text { knowledg* or outcome* or 'decisional } \\
\text { conflict') }\end{array}$ & 33900 \\
\hline$\# 16$ & user near/5 (stud* or test*) & 1038 \\
\hline$\# 15$ & usability & 276 \\
\hline$\# 14$ & pilot next/1 (test* or stud*) & 15334 \\
\hline$\# 13$ & acceptability & 5694 \\
\hline$\# 12$ & 'feasibility' near/5 (test* or stud* or evaluat*) & 6481 \\
\hline$\# 11$ & evaluation & 116006 \\
\hline$\# 10$ & MeSH descriptor: [Computer Systems] & 2946 \\
\hline
\end{tabular}




\begin{tabular}{|l|l|l|}
\hline & explode all trees & \\
\hline$\# 9$ & 'development' & 41021 \\
\hline$\# 8$ & (user or human) next/2 (centered or centred) & 147 \\
\hline$\# 7$ & $\# 1$ or \#2 or \#3 or \#4 or \#5 or \#6 & 8900 \\
\hline$\# 6$ & informed near/2 (choice* or decision*) & 1192 \\
\hline$\# 5$ & 'shared decision making' & 1299 \\
\hline$\# 4$ & computer* next/2 'decision making' & 228 \\
\hline$\# 3$ & $\begin{array}{l}\text { MeSH descriptor: [Decision Making, } \\
\text { Computer-Assisted] explode all trees }\end{array}$ & 3552 \\
\hline$\# 2$ & $\begin{array}{l}\text { decision near/3 (board* or guide* or } \\
\text { counsel*) }\end{array}$ & 544 \\
\hline$\# 1$ & $\begin{array}{l}\text { (decision* or decid*) near/4 (support* or aid* } \\
\text { or tool* or material*) }\end{array}$ & 3178 \\
\hline
\end{tabular}

\section{User-Centered Design:}

Ovid MEDLINE - Search Conducted 2014/09/26

\# Searches Results

1 'user-centred design'.mp. $\quad 55$

2 'user centered design'.mp. $\quad 185$

3 'user-centered design'.mp. $\quad 185$

4 'user centred design'.mp. $\quad 55$

5 'human-centred design'.mp. 14

6 'human centered design'.mp. 39

7 'human-centered design'.mp. 39

8 'human centred design'.mp. 14

9 or/1-8 286

Embase.com - Search Conducted 2014/09/26

\begin{tabular}{|l|l|l|}
\hline Line Number & Search String & Article Count \\
\hline$\# 9$ & $\begin{array}{l}\text { \#1 OR \#2 OR \#3 OR \#4 OR \#5 OR \#6 OR \#7 } \\
\text { OR \#8 }\end{array}$ & 345 \\
\hline$\# 8$ & 'human centred design' & 21 \\
\hline$\# 7$ & 'user centred design' & 94 \\
\hline
\end{tabular}




\begin{tabular}{|l|l|l|}
\hline$\# 6$ & 'human-centred design' & 21 \\
\hline$\# 5$ & 'user-centred design' & 94 \\
\hline$\# 4$ & 'human-centered design' & 46 \\
\hline$\# 3$ & 'user-centered design' & 191 \\
\hline$\# 2$ & 'human centered design' & 46 \\
\hline$\# 1$ & 'user centered design' & 191 \\
\hline
\end{tabular}

Cochrane Library - Search Conducted 2014/09/26

\begin{tabular}{|l|l|l|}
\hline Line Number & Search String & Article Count \\
\hline$\# 9$ & $\begin{array}{l}\text { \#1 OR \#2 OR \#3 OR \#4 OR \#5 OR \#6 OR \#7 } \\
\text { OR \#8 }\end{array}$ & 6 \\
\hline$\# 8$ & 'human centred design' & 2 \\
\hline$\# 7$ & 'user centred design' & 2 \\
\hline$\# 6$ & 'human-centred design' & 2 \\
\hline$\# 5$ & 'user-centred design' & 2 \\
\hline$\# 4$ & 'human-centered design' & 0 \\
\hline$\# 3$ & 'user-centered design' & 2 \\
\hline$\# 2$ & 'human centered design' & 0 \\
\hline$\# 1$ & 'user centered design' & 2 \\
\hline
\end{tabular}

\section{PubMed - Search Conducted 2014/09/26}

(("user centered design" OR "user-centered design" OR "user centred design" OR "user-centred design")) OR ("human centered design" OR "human-centered design" OR "human centred design" OR "human-centred design")

297 Results

Web of Science - Search Conducted 2014/09/26

\begin{tabular}{|l|l|l|}
\hline Line Number & Search String & Article Count \\
\hline$\# 3$ & \#2 OR \#1 & 2187 \\
\hline$\# 2$ & $\begin{array}{l}\text { TOPIC: (("user-centred design")) OR TOPIC: } \\
\text { (("user centred design")) OR TOPIC: (("user- } \\
\text { centered design")) OR TOPIC: (("user centered } \\
\text { design")) OR TOPIC: (("human-centred } \\
\text { design")) OR TOPIC: (("human centred } \\
\text { design")) OR TOPIC: (("human-centered } \\
\text { design")) OR TOPIC: (("human centered } \\
\text { design")) }\end{array}$ & 2187 \\
\hline$\# 1$ & $\begin{array}{l}\text { TITLE: (("user-centred design")) OR TITLE: } \\
\text { (("user centred design")) OR TITLE: (("user- } \\
\text { centered design")) OR TITLE: (("user centered } \\
\text { design")) OR TITLE: (("human-centred } \\
\text { design")) OR TITLE: (("human centred } \\
\text { design")) OR TITLE: (("human-centered }\end{array}$ & \\
\hline
\end{tabular}




\section{IEEE Xplore - Search Conducted 2014/09/29}

(("user centered design" or "user centred design" or "user-centered design" or "user-centred design") OR "human centered design" or "human centred design" or "human-centered design" or "human-centred design")

528 Results

\section{Stacey RCT Search}

\section{CINAHL - Search Conducted 2015/07/09}

\# Query Results

$\begin{array}{lll}\text { S28 } & \text { S17 and S27 Limiters - Exclude MEDLINE records } & 1,478\end{array}$

S27 S18 or S19 or S20 or S21 or S22 or S23 or S24 or S25 or S26 316,150

S26 TI (singl* or doubl* or tripl* or trebl*) and TI (blind* or mask*) $\quad 8,385$

S25 AB (singl* or doubl* or tripl* or trebl*) and AB (blind* or mask*) $\quad 18,302$

S24 AB (random* or trial or placebo*) or TI (random* or trial or placebo*) $\quad 190,656$

$\begin{array}{ll}\text { S23 MH Quantitative Studies } & 13,556\end{array}$

$\begin{array}{lrr}\text { S22 MH Placebos } & 9,296\end{array}$

S21 MH Random Assignment $\quad 39,367$

$\begin{array}{lr}\text { S20 MH Clinical Trials+ } & 189,073\end{array}$

$\begin{array}{ll}\text { S19 PT Clinical Trial } & 78,151\end{array}$

S18 PT "randomi?ed controlled trial” $\quad 50,591$

$\mathrm{S} 17 \mathrm{~S} 1$ or $\mathrm{S} 2$ or $\mathrm{S} 3$ or $\mathrm{S} 4$ or $\mathrm{S} 5$ or $\mathrm{S} 6$ or $\mathrm{S} 7$ or $\mathrm{S} 8$ or $\mathrm{S} 9$ or $\mathrm{S} 10$ or $\mathrm{S} 11$ or $\mathrm{S} 12$ or $\mathrm{S} 13$ or $\mathrm{S} 14$ or $\mathrm{S} 15$ or S16 $\quad 99,603$

S16 "informed choice*" or "informed decision*” 2,662

$\begin{array}{ll}\text { S15 "shared decision making" } & 1,468\end{array}$

$\begin{array}{ll}\text { S14 "adaptive conjoint analys?s" } & 13\end{array}$

S13 (interactive N2 "risk information") or (interactive N2 "risk communication") or 
(interactive N2 "risk presentation") or

(interactive N2 "risk graphic*")

S12 "interactive internet" or "interactive online" or "interactive graphic*" or "interactive booklet*" or (interacti* N3 tool*) 406

S11 "interactive health communication*" 25

$\begin{array}{ll}\text { S10 computer* N1 “decision making” } & 1,072\end{array}$

S9 ("risk communication" N3 tool*) or ("risk communication" N3 method*) or ("risk information" N3 tool*) or ("risk information" N3 method*) or ("risk assessment" N3 tool*) or ("risk assessment" N3 method*) 6,979

S8 "evidence based risk communication" or "evidence based risk information" 6

S7 "decision board*" or "decision guide*" or "decision counseling" 50

S6 (decision* N3 support*) or (decision* N3 aid*) or (decision* N3 tool*)

or (decision* N3 instrument*) or (decision* N3 technolog*)

or (decision* N3 technique*) or (decision* N3 system*)

or (decision* N3 program*) or (decision* N3 algorithm*)

or (decision* N3 process*) or (decision* N3 method*)

or (decision* N3 intervention*) or (decision* N3 material*) $\quad 19,551$

S5 "decision making" or "choice behavior" and MH consent $\quad 81,704$

$\begin{array}{lll}\text { S4 } & \text { MH decision making, computer assisted } & 1,049\end{array}$

$\begin{array}{lr}\text { S3 MH decision making, patient } & 11,144\end{array}$

$\begin{array}{ll}\text { S2 } & \text { MH decision support systems, clinical }\end{array}$

$\begin{array}{lll}\text { S1 mh decision support techniques+ } & 4,578\end{array}$

Cochrane Library - Search conducted 2015/07/15

ID Search Hits

\#1 (decision-support or decision-aid):kw in Trials 1140

\#2 decision-tree:kw in Trials 42 
\#3 patient-decision-making:kw

\#4 (decision-making or choice-behavior):ti,ab,kw

and (informed-consent:kw,ti

or (patient or parent* or carer or caregiver or care- giver):ti,ab,kw)

in Trials

\#5 ((decision or decid*) near/4

(support* or aid* or tool or instrument or technolog* or technique or system or program* or algorithm or process or method

or intervention or material)):ti,ab,kw

\#6 (decision next (board or guide or counseling)):ti,ab,kw

\#7 ((risk-communication or risk-assessment or risk-information)

near/4 (tool or method)):ti,ab,kw

\#8 (computer* near/2 decision-making):ti,ab,kw

\#9

(interactive-health-communication or (interacti* near/4 tool)):ti,ab,kw 46

$\# 10$ (interactive next (internet or online or graphic* or booklet)):ti,ab,kw

\#11 ((interactiv* or evidence-based) near/3 (risk-information or risk-communication or risk-presentation or risk-graphic*)):ti,ab,kw 6

\#12 shared-decision-making:ti,ab,kw 267

\#13 (informed next (choice or decision)):ti,ab,kw 263

\#14 adaptive-conjoint-analysis:ti,ab,kw

3

\#15 (\#1 or \#2 or \#3 or \#4 or \#5 or \#6 or \#7 or \#8 or \#9 or \#10 or \#11

or \#12 or \#13 or \#14)

\#16 decision:ti,ab

\#17 patient:ti,ab

\#18 consumer:ti,ab

\#19 \#16 and (\#17 or \#18)

\#20 shared decision making:ti,ab 356

\#21 decision aid\$:ti,ab 
Trials -4798

\section{EMBASE - Search Conducted 2015/07/09}

'decision support system'/exp OR 'patient decision making'/exp OR 'decision aid' OR 'decision tree'/exp OR ('decision making':ab,ti AND 'informed consent':ab,ti) OR ((decision* OR decid*) NEAR/4 (support* OR aid* OR tool* OR instrument* OR technolog* OR technique* OR system* OR program* OR algorithm* OR process* OR method* OR intervention* OR material*)):ab,ti OR decision NEAR/1 (board* OR guide* OR counseling) OR ('risk communication' OR 'risk assessment' OR 'risk information') NEAR/4 (tool* OR method*) OR computer* NEAR/2 'decision making' OR interactive NEXT/1 health NEXT/1 communication* OR interactive NEAR/1 (internet OR online OR graphic* OR booklet*) OR interacti* NEAR/4 tool* OR (interactiv* OR 'evidence based') NEAR/3 ('risk information' OR 'risk communication' OR 'risk presentation' OR 'risk graphic' OR 'risk graphics') OR 'shared decision making' OR informed NEAR/1 (choice* OR decision*) OR adaptive NEXT/1 conjoint NEXT/1 analys?s AND ('randomized controlled trial'/exp OR 'controlled clinical trial'/exp OR 'single blind procedure'/exp OR 'double blind procedure'/exp OR 'crossover procedure'/exp OR random* OR placebo* OR (singl* OR doubl*) NEAR/1 (blind* OR mask*) OR crossover OR 'cross over' OR factorial* OR 'latin square' OR assign* OR allocat* OR volunteer*) NOT ('nonhuman'/exp NOT ('human'/exp AND 'nonhuman'/exp)) NOT [medline]/lim OR ('decision making'/exp OR 'decision theory'/exp OR decision\$ OR 'educational technology'/exp AND ('health behavior'/exp OR 'patient attitude'/exp OR 'health education'/exp OR 'informed consent' OR patient OR consumer) OR (patient\$ OR consumer\$) NEAR/1 (decision\$ OR choice OR preference OR participation) OR (women OR men) NEAR/1 (decision\$ OR choice OR preference OR participation) OR parent\$ NEAR/1 (decision\$ OR choice OR preferenc\$ OR participat\$) OR (personal OR interpersonal OR individual) NEAR/1 (decision\$ OR choice OR preference\$ OR participat\$) OR 'shared decision making' OR decision NEXT/1 aid\$ OR 'informed choice' AND ('randomized controlled trial'/exp OR 'controlled clinical trial'/exp OR 'single blind procedure'/exp OR 'double blind procedure'/exp OR 'crossover procedure'/exp OR random* OR placebo* OR (singl* OR doubl*) NEAR/1 (blind* OR mask*) OR crossover OR 'cross over' OR factorial* OR 'latin square' OR assign* OR allocat* OR volunteer*) NOT ('nonhuman'/exp NOT ('human'/exp AND 'nonhuman'/exp)) NOT [medline]/lim) AND [20112015]/py

8917 Hits 


\section{\# Searches}

Results

1 decision support techniques/

13785

2 decision support systems clinical/

5325

3 decision trees/

9233

4 (decision making or choice behavior).mp. and informed consent.sh.

4424

((decision* or decid*) adj4 (support* or aid* or tool* or instrument* or

5 technolog* or technique* or system* or program* or algorithm* or process* or method* or intervention* or material*)).tw.

6 (decision adj (board* or guide* or counseling)).tw.

131

((risk communication or risk assessment or risk information) adj4 (tool* or
method*)).tw.

8 decision-making computer assisted/

9 (computer* adj2 decision making).tw.

161

10 interactive health communication*.tw.

54

11 (interactive adj (internet or online or graphic* or booklet*)).tw.

529

12 (interacti* adj4 tool*).tw.

13 ((interactiv* or evidence based) adj3 (risk information or risk communication or risk presentation or risk graphic*)).tw.

14 shared decision making.tw.

15 (informed adj (choice* or decision*)).tw.

6095

16 adaptive conjoint analys\#s.tw.

39

17 or/1-16

88294

18 randomized controlled trial.pt.

405032 
21 placebo.ab. 
41 ((patient\$ or consumer\$) adj1 (decision\$ or choice or preference or participation)).tw.

42 ((women or men) adj1 (decision\$ or choice or preference or participation)).tw. $\quad 282$

43 (parent\$ adj1 (decision\$ or choice or preferenc\$ or participat\$)).tw.

44 ((personal or interpersonal or individual) adj (decision\$ or choice or preference\$ 3624 or participat\$)).tw.

45 shared decision making.tw.

2829

46 decision aid\$.tw.

47 informed choice.tw.

1062

48 or/29-35

634345

49 or/36-40

2200111

$50 \quad 48$ and 49

161265

51 or/41-47 20949

5250 or 51 169374

53 clinical trial.pt.

502914

54 randomized controlled trial.pt.

405032

55 random\$.tw.

786219

56 (double adj blind\$).tw.

123876

57 double-blind method/

133324

58 or/53-57

1183857

5952 and 58

20340

6028 not 59

4032

6128 or 59 


\section{PsycINFO - Search Conducted 2015/07/09}

\# Search

Results

1 decision support systems/

2 (decision making or choice behavior).mp. and (informed consent.sh.

or (patient* or parent* or carer* or caregiver* or care giver*).mp.)

3 ((decision* or decid*) adj4 (support* or aid* or tool* or instrument* or technolog* or technique* or system* or program* or algorithm* or process* or method* or intervention* or material*)).ti,ab,id.

4 (decision adj (board* or guide* or counseling)).ti,ab,id.

5 ((risk communication or risk assessment or risk information) adj4 (tool* or method*)).ti,ab,id.

6 computer assisted therapy/

7 (computer* adj2 decision making).ti,ab,id.

8 interactive health communication*.ti,ab,id.

9 (interactive adj (internet or online or graphic* or booklet*)).ti,ab,id.

10 (interacti* adj4 tool*).ti,ab,id.

11 ((interactiv* or evidence based) adj3 (risk information or risk communication or risk presentation or risk graphic*)).ti,ab,id.

12 shared decision making.ti,ab,id.

13 (informed adj (choice* or decision*)).ti,ab,id.

14 adaptive conjoint analys\#s.ti,ab,id.

15 or/1-14

16 random*.ti,ab,hw,id.

17 intervention.ti,ab,hw,id.

18 trial.ti,ab,hw,id.

19 placebo*.ti,ab,hw,id. 
20 ((singl* or doubl* or trebl* or tripl*) and (blind* or mask*)).ti,ab,hw,id. (23459)

21 (cross over or crossover).ti,ab,hw,id.

(7681)

22 latin square.ti,ab,hw,id.

23 (assign* or allocat* or volunteer*).ti,ab,hw,id.

24 treatment effectiveness evaluation/

25 mental health program evaluation/

26 exp experimental design/

27 or/16-26

$28 \quad 15$ and 27

\section{PRISMA Flow Diagram}

\begin{tabular}{|l|l|l|l|}
\hline Database & Search Approach & Article Count & Date Searched \\
\hline IEEE Xplore & $\begin{array}{l}\text { User-Centred } \\
\text { Design }\end{array}$ & 528 & $2014 / 09 / 29$ \\
\hline Web of Science & $\begin{array}{l}\text { User-Centred } \\
\text { Design }\end{array}$ & 2187 & $2014 / 09 / 26$ \\
\hline PubMed & $\begin{array}{l}\text { User-Centred } \\
\text { Design }\end{array}$ & 297 & $2014 / 09 / 26$ \\
\hline Cochrane Library & $\begin{array}{l}\text { User-Centred } \\
\text { Design }\end{array}$ & 6 & $2014 / 09 / 26$ \\
\hline Embase.com & $\begin{array}{l}\text { User-Centred } \\
\text { Design }\end{array}$ & 345 & $2014 / 09 / 26$ \\
\hline Ovid MEDLINE & $\begin{array}{l}\text { User-Centred } \\
\text { Design }\end{array}$ & 286 & $2014 / 09 / 26$ \\
\hline Cochrane Library & Decision Aids & 5524 & $2014 / 04 / 30$ \\
\hline Embase (Embase.com) & Decision Aids & 20,438 & $2014 / 05 / 01$ \\
\hline MEDLINE (Embase.com) & Decision Aids & 19,444 & $2014 / 05 / 01$ \\
\hline Web of Science & Decision Aids & 15,597 & $2014 / 05 / 11$ \\
\hline Web of Science & Referencing Elwyn & 322 & $2014 / 05 / 01$ \\
\hline CINAHL & RCT Search & 1478 & $2015 / 07 / 09$ \\
\hline Cochrane Library & RCT Search & 4798 & $2015 / 07 / 15$ \\
\hline Embase (Embase.com) & RCT Search & 8917 & $2015 / 07 / 09$ \\
\hline Ovid MEDLINE & RCT Search & 24,372 & $2015 / 07 / 09$ \\
\hline Ovid PsycINFO & RCT Search & 9249 & $2015 / 07 / 09$ \\
\hline $\begin{array}{l}\text { References Not } \\
\text { Included in Stacey } \\
\text { Cochrane Review }\end{array}$ & & 10 & $2014 / 09 / 30$ \\
\hline & & & \\
\hline & & & \\
\hline & & & \\
\hline
\end{tabular}




\begin{tabular}{|c|c|c|c|}
\hline $\begin{array}{l}\text { Results of Reference } \\
\text { Searching of Screened } \\
\text { Articles }\end{array}$ & & 16 & \\
\hline $\begin{array}{l}\text { Cited in Searches in the } \\
\text { Stacey Cochrane } \\
\text { Review }\end{array}$ & & 46 & \\
\hline \multicolumn{4}{|c|}{ Other Screening Results } \\
\hline Combined & Decision Aids & 39465 & $2014 / 05 / 11$ \\
\hline Combined & User Centered & 3500 & $2014 / 09 / 26$ \\
\hline $\begin{array}{l}\text { Title and Abstract } \\
\text { Screening }\end{array}$ & Decision Aids & 662 Articles Retained & $2014 / 06 / 16$ \\
\hline $\begin{array}{l}\text { Title and Abstract } \\
\text { Screening }\end{array}$ & User Centered & 153 Articles Retained & $2014 / 06 / 30$ \\
\hline Full-Text Screening & Decision Aids & 366 Articles Retained & $2014 / 06 / 30$ \\
\hline Full-Text Screening & User Centered & 76 Articles Retained & \\
\hline RCT Search & RCT Search & 40,476 Articles & $2015 / 07 / 09$ \\
\hline $\begin{array}{l}\text { Title and Abstract } \\
\text { Screening }\end{array}$ & RCT Search & 163 Articles Retained & \\
\hline Full Text Screening & RCT Search & 23 Articles Retained & $2015 / 09 / 03$ \\
\hline $\begin{array}{l}\text { Total Articles from All } \\
\text { Searches }\end{array}$ & & 537 Articles & \\
\hline
\end{tabular}




\section{PRISMA Flow Diagram}

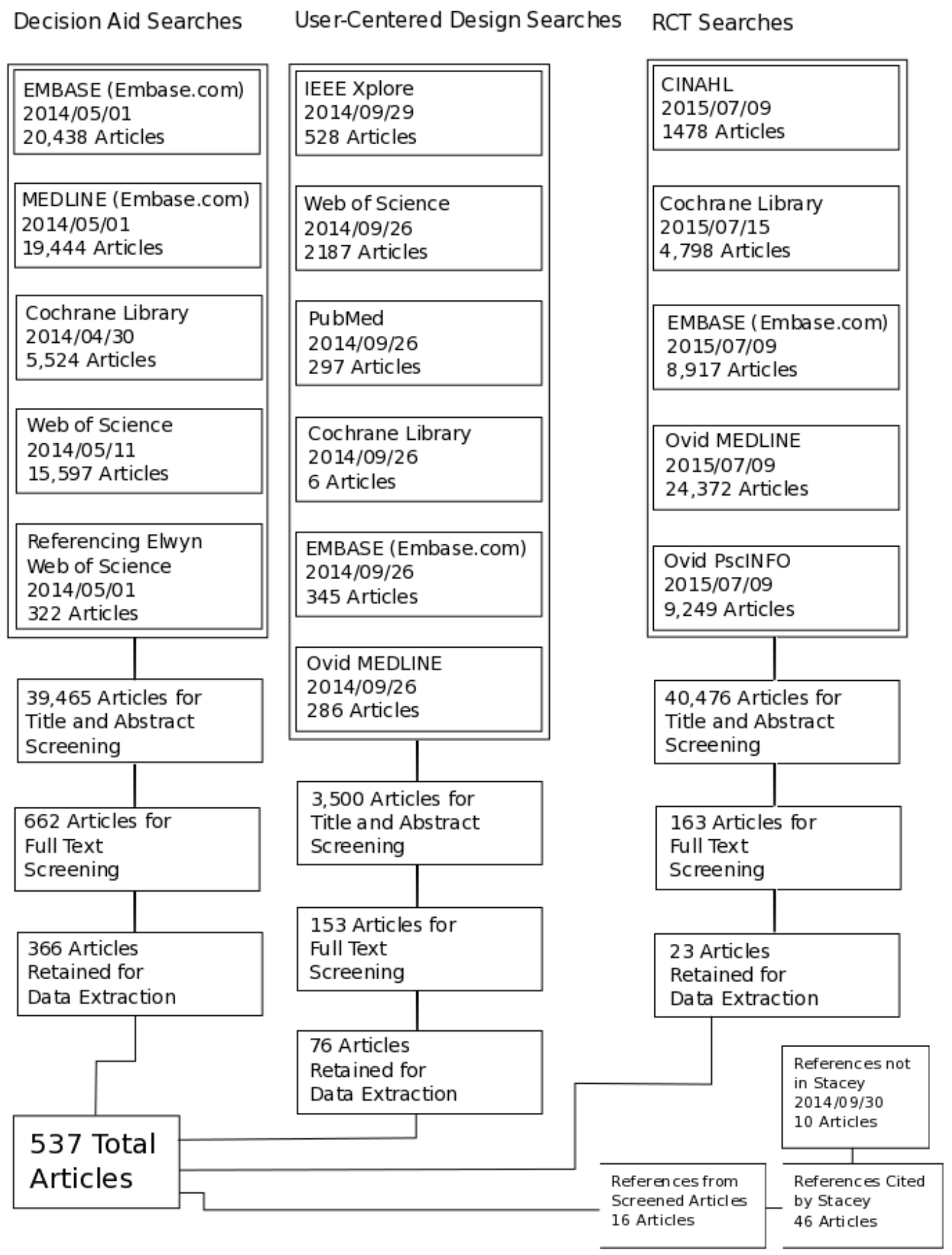




\section{Appendix 2 : Draft Data Extraction Plan}

When assigning data extraction pairs, have a step between to avoid double entry.

\section{Global Definitions (in addition to those that appear right in the question):}

- PFCS (patient/family and friends/caregiver/surrogate) users (actual or potential) are people who are (= actual) or who might be (= potential) either:

0 patients who might use this tool to address their own personal health issue,

- family and friends who might support a patient through this health issue (but who are not yet caregivers or surrogate decision makers),

- caregivers of people with a health issue (meaning they provide practical care and support full- or part-time), or

- surrogate decision makers for someone with a health issue (meaning the person is incapacitated and the surrogate must make decisions on their behalf, also includes proxy decision makers, i.e., those who were not necessarily identified ahead of time)

- Clinician users (actual or potential): Health care professionals who: (1) provide care to people who face this health issue, (2) are not career researchers, and (3) have no stake in showing that the tool/decision aid works.

- $\quad$ Not reported $=$ Authors do not mention this

- Unclear = may be mentioned but not clear what was done

\section{Acronyms:}

PFCS $=$ patient/family and friends/caregiver/surrogate

$\mathrm{UCD}=$ user-centered design

$\mathrm{HCD}=$ human-centered design 


\section{Identification}

Research assistant name: [automatic]

Date of extraction: [automatic]

[ ] Flag for exclusion (on second reading, this may not relevant after all -> STOP extracting, go on to next article, we will discuss this at next team meeting)

1. Article ID [number from screening process]:

Number is from (check one):

Main search

$\square$ UCD/HCD search

$\square$ Hand searches

2. First author last name (will be used to link articles):

3. Corresponding author last name (will be used for mail merge):

$\square$ Check if corresponding author is first author

4. Corresponding author email:

5. Does this article have to do with a decision aid or something else? (check one)

Decision aid

Other

6. Name of decision aid or tool (if available):

7. [ ] This article references other linked articles (e.g., an evaluation article that cites development in another article, or , occasionally, a development article citing an evaluation article)

copy and paste reference(s):

first author of reference 1 (will be used to link articles):

first author of reference 2 (will be used to link articles):

first author of reference 3 (will be used to link articles): 
REMINDER All articles in this review should fall into at least one of these circles:

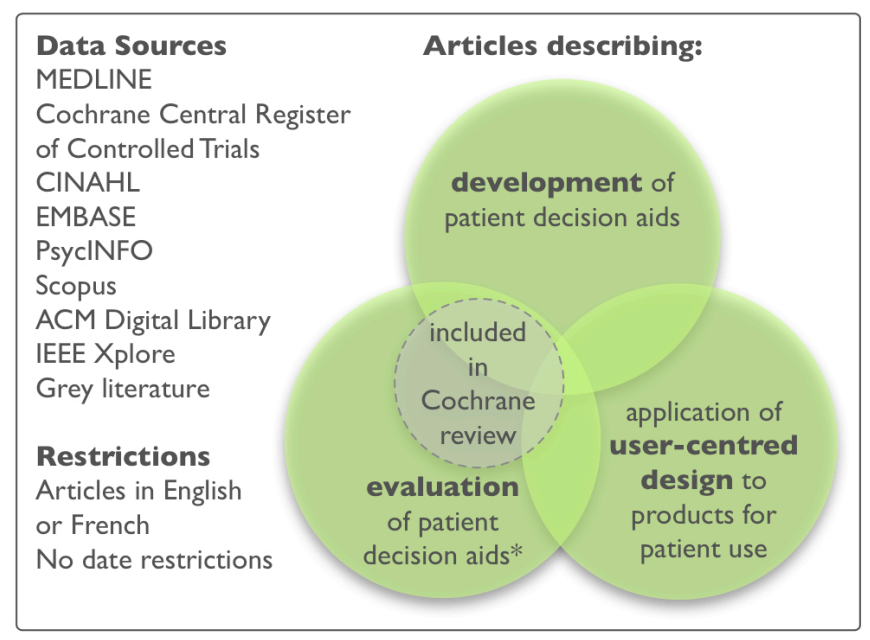

Not to scale. (Elements of diagram may not be proportionally representative.)

*Includes all types of evaluation studies, e.g., trials, pilot, feasibility, etc.

8. Does this article describe (check all that apply):

Development of a patient decision aid (PtDA) or other patient oriented tool (at least one step described)?

Evaluation of a patient decision aid (PtDA) or other patient oriented tool?

User-centered design for a patient decision aid (PtDA) or other patient oriented tool?

Comments

9. Does this report describe (check all that apply): (should always be checked for evaluation articles, may or may not be checked for development articles)

$\square$ Evaluation of any of: feasibility, acceptability, satisfaction with tool/decision aid, usability, other preliminary metric of evaluation (typically measured BEFORE implementation)

$\square$ Evaluation of efficacy (e.g., capacity to increase patient knowledge or decrease decisional conflict within the context of a formal study, e.g., RCT) or Effectiveness (e.g., effects in real-world conditions - this is effects on patients)

$\square$ Evaluation of implementation (e.g., integration into routine care, barriers and facilitators to usage, uptake, how many times decision aid used over period of time - this is things like usage statistics)

$\square$ Other

$\square$ None of the above reported

Comments

10. What clinical context is addressed by this decision aid or tool? (check all that apply):

\section{Cancer}
- Prostate
- Breast
- Ovarian
- Colorectal
- Lung
o Other: 
$\square$ Chronic Conditions

○ Diabetes

- Chronic Obstructive Pumonary Disorder (COPD)

- Cardiovascular Health (Heart disease, stroke, etc.)

- Disability

- Other:

Reproductive Health

Advanced Care Planning

Vaccine Preventable Diseases

Not reported

Other:

N.B. We will check the "Other" fields regularly to see if we have new categories that need to be added

11. What type of decision or health issue is addressed by this decision aid or tool? (check all that apply):

$\square$ Prevention

$\square$ Genetic Testing

$\square$ Screening

$\square$ Diagnostic Testing

$\square$ Treatment

$\square$ Everyday Life

$\square$ Not reported

$\square$ Unclear

$\square$ Other:

N.B. We will check the "Other" fields regularly to see if we have new categories that need to be added

[LOGIC: Before moving on to next page, validate that if any of the first three options for question 9 are checked, then Evaluation is checked in question 8. 
12. Does the article describe any guideline, theory, framework or model on which the tool was based/developed? (check all that apply):

$\square$ Analytic Hierarchy Process

$\square$ Differentiation and Consolidation Theory

$\square$ Edutainment Decision Aid Model (EDAM)

$\square$ Elaboration Likelihood Model

$\square$ Expected Utility Theory

$\square$ Fast and Frugal Heuristics

$\square$ International Patient Decision Aid Standards (IPDAS)

$\square$ Multiattribute Utility Theory

$\square$ Ottawa Decision Support Framework

$\square$ Precaution Adoption Model

$\square$ Preventive Health Model

$\square$ Stages of Change

$\square$ Theory of Planned Behaviour

$\square$ User-centered design

$\square$ Other theory/framework/model (IMPORTANT: We will check this regularly)

$\square$ No theory/framework reported (go to next question) 


\section{Questions about TOOL}

13. Format of tool (check all that apply):

$\square$ Paper (booklet, leaflet, etc.)

$\square$ Paper delivered online (printable pdf file, pdf emailed, etc.)

$\square$ Recording (DVD/laser disc, audio tape, video - not Internet video)

$\square$ Conversation (discussion guided by a list, decision board, etc.)

$\square$ Electronic application - not online (look for words: CD-ROM, computer program)

$\square$ Online application (look for words: online/Internet/Web-based)

$\square$ Mobile App (look for words: native apps, mobile-enabled websites intended for use on mobile devices)

$\square$ Offered in multiple formats (can be used separately, e.g., a paper version and web version, choose which one you want; option to print summary at end of web-based version)

$\square$ Requires multiple formats (e.g., booklet with an audiotape)

$\square$ Other

Not reported

$\square$ Unclear

Comments

14. Context in which the tool is intended be used (check all that apply, do not interpret, report what the authors say):

$\square$ At home or in a private setting

$\square$ In a health care setting but not during a clinical encounter (in waiting room, in a separate room, etc. - no clinician present)

$\square$ During an in-person clinical encounter (requires clinician presence)

$\square$ During a virtual clinical encounter (e.g., telemedicine)

$\square$ Everyday life (can be used everywhere, e.g., wheelchair)

$\square$ Other

$\square$ Not reported

$\square$ Unclear

Comments

15. Timing of tool usage (check all that apply, do not interpret, report what the authors say):

$\square$ Before clinical encounter (in preparation for discussion)

$\square$ During clinical encounter [LOGIC: Automatically check if previous is during clinical encounter]

$\square$ Between clinical encounter

$\square$ Not associated with clinical encounter

$\square$ Other (e.g., After clinical appointment with no intention for followup, e.g. to support a decision already made)

Not reported

Unclear

Comments 


\section{Questions about DEVELOPMENT process}

REMINDER We are using this framework of user-centred design:

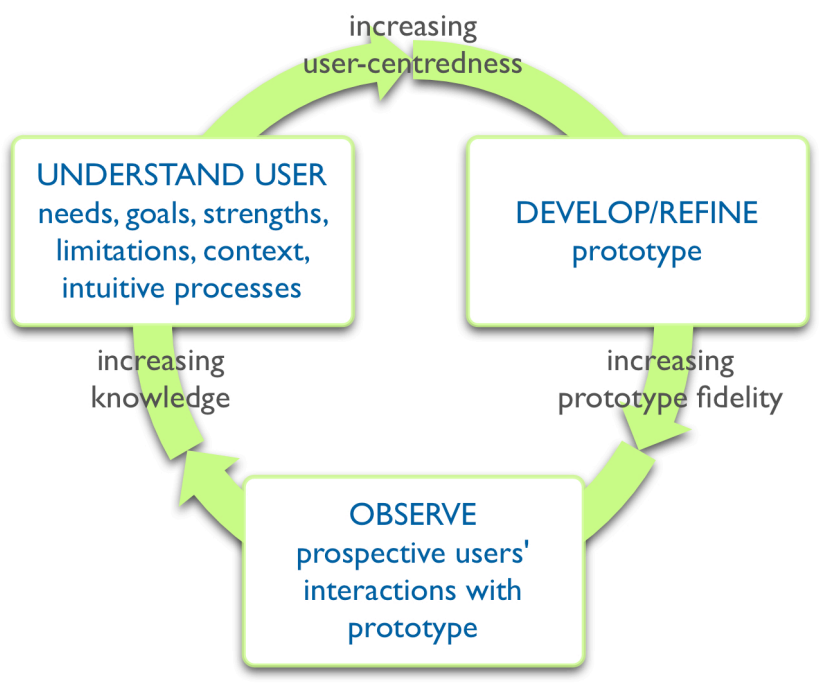

16. Did the development team go through the following development steps?

Literature review (reviewing articles, reading about the issue, etc.) (choose one)
- Yes
- No/Not reported
○ Unclear
- Not applicable (evaluation report)

Observation of existing processes (sitting in the room, video-recording the process, some other way of recording/observing the process, etc.) (choose one)
○ Yes
- No/Not reported
○ Unclear
- Not applicable (evaluation report)

Formal needs assessment (formal = calls itself a needs assessment) (choose one)
- Yes
- No/Not reported
○ Unclear
- Not applicable (evaluation report)

Informal needs assessment (informal = doesn't use the term needs assessment, but that's what they were looking for, e.g., we previously interviewed patients ...) (choose one)
○ Yes
- No/Not reported
- Unclear
- Not applicable (evaluation report) 
Develop and/or validate underlying model (e.g., decision analytic model, look for terms: Markov, decision tree, microsimulation) (choose one)

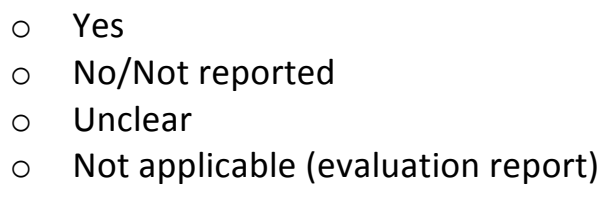

Storyboarding, wireframing (may or may not be called storyboarding, involves sketching out what the tool is going to look like and the different steps involved in using it) (choose one)

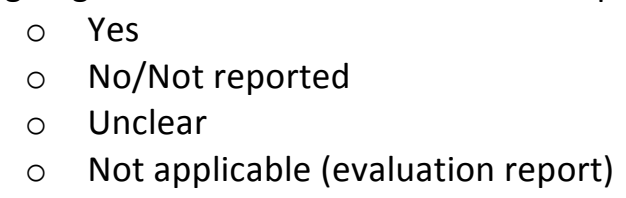

Adapt, translate tool (e.g., language, literacy level, clinical context, e.g., breast to prostate cancer, watch for author names: O'Connor, Stacey) (choose one)
○ Yes
- No/Not reported
○ Unclear
- Not applicable (evaluation report)

Content review PRIOR to prototype development (often, but not always, done with an "expert panel") (choose one)
○ Yes
- No/Not reported
○ Unclear
- Not applicable (evaluation report)

Prototype development (may have $>1$ round of development) (choose one)

- Yes

- No/Not reported

○ Unclear

- Not applicable (evaluation report)

Content/format review (this means looking at the tool but not using it) AFTER prototype development (choose one)
○ Yes
- No/Not reported
- Unclear

Pilot/usability testing (this means using the tool) (choose one)
- Yes
- No/Not reported
- Unclear

They did something with the prototype but I'm unclear whether it's content/format review or pilot/usability testing 
Other step

Other step

Other step

Other step

17. In what order \& how many participants?

\begin{tabular}{|c|c|c|c|c|c|}
\hline & $\begin{array}{l}\text { Order (1 = first } \\
\text { step, } 2 \text { = } \\
\text { second step, } \\
\text { etc. If multiple } \\
\text { steps were } \\
\text { done at the } \\
\text { same time, } \\
\text { use the same } \\
\text { number for } \\
\text { each. } \\
U=\text { order } \\
\text { unclear } \\
\text { NR = order not } \\
\text { reported.) }\end{array}$ & $\begin{array}{l}\text { Were PFCS users (actual or } \\
\text { potential) involved in this } \\
\text { step? }(Y=\text { yes, } N=\text { no, } U= \\
\text { unclear, } N R=\text { not reported) }\end{array}$ & $\begin{array}{l}\text { If yes, how } \\
\text { many? } \\
\text { (report } \\
\text { number, } 0= \\
\text { none, } U= \\
\text { number } \\
\text { unclear, NR = } \\
\text { number not } \\
\text { reported) }\end{array}$ & $\begin{array}{l}\text { If yes, how } \\
\text { many of the } \\
\text { number on } \\
\text { the left were } \\
\text { NEW users } \\
\text { (i.e., people } \\
\text { who had not } \\
\text { seen the } \\
\text { tool/decision } \\
\text { aid before)? } \\
\text { (report } \\
\text { number, } 0= \\
\text { none, } U= \\
\text { number } \\
\text { unclear) }\end{array}$ & $\begin{array}{l}\text { If yes, were } \\
\text { they involved } \\
\text { individually } \\
\text { (i.e., via } \\
\text { interviews) or } \\
\text { in groups (i.e., } \\
\text { via focus } \\
\text { groups)? } \\
\text { IN = } \\
\text { interviews, FG } \\
=\text { focus } \\
\text { groups, B = } \\
\text { both, U = } \\
\text { unclear, NR = } \\
\text { not reported, } \\
\text { O = other } \\
\text { (explain in } \\
\text { comment) }\end{array}$ \\
\hline $\begin{array}{l}\text { Step checked } \\
\text { off above }\end{array}$ & & & & & \\
\hline $\begin{array}{l}\text { Step checked } \\
\text { off above }\end{array}$ & & & & & \\
\hline Etc. & & & & & \\
\hline
\end{tabular}

18. Was there an iterative development process? (Looks for mention of initial version, final version, etc.) (choose one)
○ Yes
○ No
- Not reported
- Unclear

19. If $18=$ yes, how many cycles were there? (Recall: One cycle $=$ one prototype/version, each new cycle = showed it to someone, made a change to create new prototype) (choose one)

o Exactly this many 
At least this many ___ unclear on whether there were more
$\circ$ At least this many $\_$and probably more (subjective judgment)
$\circ \quad$ Unclear

20. If $18=$ yes, do the authors describe what changes were made between versions/prototypes? (choose one)

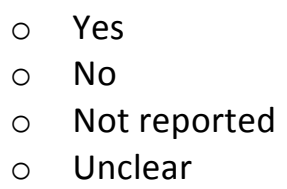

21. In my opinion, this development process was: (OPTIONAL, check all that apply, highly subjective, we are flagging this for additional reading/citation)

A very good development process

$\square$ A very clearly described process

Other comments

22. After having any working prototype (initial version, final version, etc.) of their tool, does the article indicate that the developers did any of the following ... (check all that apply)

ASK words to look for as clues: semi-structured interviews, focus groups, opinions, satisfaction, etc.

ASK PFCS users (actual or potential) their thoughts \& opinions of the tool

ASK clinician users their thoughts \& opinions of the tool

$\square$ ASK non-users (e.g., content experts, steering committee, etc.) their thoughts \& opinions of the tool

OBSERVE (often real time; words to look for as clues: "think-aloud ", usability testing, pilot testing, etc.)

OBSERVE PFCS users (actual or potential) interacting with the tool

OBSERVE clinician users interacting with the tool

OBSERVE non-users (e.g., content experts, steering committee, etc.) interacting with the tool

ASSESS the impact of the tool (often afterwards; words to look for as clues: measure, collected, questionnaire, instrument, etc.)

ASSESS the impact of the tool on PFCS users (actual or potential)

ASSESS the impact of the tool on clinician users

ASSESS the impact of the tool on non-users (e.g., content experts, steering committee, etc.) 
23. Were PFCS users (potential or actual) involved: (check all that apply)

$\square$ On the research/development team (look at author list for clues)

$\square$ In a separate advisory capacity (e.g., patient advisory committee, individual patients consulted as advisors)

$\square$ As participants in studies

$\square$ Other

$\square$ Other

$\square$ Other

Not reported

$\square$ Unclear

Comments

24. Was there a PFCS advisory panel (e.g., patient steering committee) involved? (do not interpret, report what they say) (check one)

$\square$ Yes

$\square$ No

$\square$ Not reported

$\square$ Unclear

Comments

25. Was the involvement approved by an ethics board?

26. Were the following kinds of users involved?

(a) Patients/members of the public
○ Yes
- No
- Not reported
○ Unclear

IF YES when did/might they face the situation (health issue):

- Faced this situation in the past (e.g., they have made this decision before, they could have used this tool before)

- Are currently facing this situation (e.g., actually making this decision now, need this tool now)

- Might face this situation in future (often general public)

- Have not and will not face this situation

- Not reported

○ Unclear

(b) Family members/Friends (not caregivers, not surrogates, just there to support)
○ Yes
- No
- Not reported
- Unclear 
IF YES when did/might they face the situation (health issue):

$\bigcirc$ Faced this situation in the past (e.g., they have made this decision before, they could have used this tool before)

- Are currently facing this situation (e.g., actually making this decision now, need this tool now)

- Might face this situation in future

- Have not and will not face this situation

- Not reported

○ Unclear

(c) Caregivers
○ Yes
○ No
- Not reported
○ Unclear

IF YES when did/might they face the situation (health issue):

- Faced this situation in the past (e.g., they have made this decision before, they could have used this tool before)

- Are currently facing this situation (e.g., actually making this decision now, need this tool now)

- Might face this situation in future

- Have not and will not face this situation

- Not reported

- Unclear

\section{(d) Surrogate decision-makers}

○ Yes

○ No

- Not reported

- Unclear

IF YES when did/might they face the situation (health issue):

- Faced this situation in the past (e.g., they have made this decision before, they could have used this tool before)

- Are currently facing this situation (e.g., actually making this decision now, need this tool now)

- Might face this situation in future

- Have not and will not face this situation

- Not reported

$\circ$ Unclear

27. If any of 26 are Yes, are the following sociodemographic characteristics of PFCS users reported (look for a Table 1)?

(a) Age

○ Yes

- Not reported 
- Unclear

(b) Gender

○ Yes

- Not reported

- Unclear

(c) Race and/or Ethnicity
O Yes
- Not reported
- Unclear

(d) Education

o Yes

- Not reported

- Unclear

(e) Income
o Yes
- Not reported
- Unclear

(f) Literacy or Health Literacy
o Yes
- Not reported
- Unclear

(g) Numeracy or Subjective Numeracy
o Yes
- Not reported
- Unclear

(h) Clinical Characteristics (e.g., stage of disease, some measure of health)
O Yes
- Not reported
○ Unclear

28. What kinds of disadvantaged and/or underserved populations were represented in this development process? (check all that apply, N.B. there may be overlaps in the categories; checking these boxes will trigger a second reading of this article, these will not be left as the final word.)

$\square$ People who may be disadvantaged and/or underserved due to physical characteristics (e.g., race, ethnicity, age $>65$, age $<18$, sex, gender, gender identity, sexual orientation, etc.)

- Comments

People who may be disadvantaged and/or underserved due to health characteristics (e.g., comorbidities or multimorbidity, terminal illness, visual or hearing disability, other kind of disability, etc.)

- Comments 
People who may be disadvantaged and/or underserved due to psychological characteristics (e.g., mental illness, lack of social support, etc.)

- Comments

People who may be disadvantaged and/or underserved due to cognitive characteristics (e.g., low literacy or health literacy, low numeracy, learning differences, dementia, etc.)

- Comments

People who may be disadvantaged and/or underserved due to socioeconomic characteristics (e.g., education, income, rural or remote location, recent immigrants, housing insecurity, food insecurity, less access to care, speak a different language than the local language, low Internet access, etc.)

- Comments

People who may be disadvantaged and/or underserved due to potential discrimination or stigma in the health care system (e.g., people who are obese, who have alcohol or drug dependencies, who are sex workers, etc.)

○ Comments

$\square$ Other

$\square$ Other

$\square$ Other

$\square$ None of the above

29. How were PFCS users recruited? (check all that apply)

$\square$ Convenience sample ("our clinic", "3 clinics")

$\square$ Snowball sampling (authors will use this word)

$\square$ Purposive sampling (authors may use this word, may refer to quotas)

$\square$ Community groups (e.g., support groups, community centres)

$\square$ Registries

Flyers/posters

$\square$ Online panel (includes MTurk)

$\square$ Random sample

$\square$ Not reported

$\square$ Unclear

Comments

30. Were PFCS users compensated/incentivized in any way?

Yes (check all that apply)

o cash

- gift cards/points

- parking/transportation

- drawings/lottery

- refreshments

- unclear

o other

No, no funds or equivalent exchanged hands in any way

Not reported

Comments

31. Did the research team consult with clinician users who were not researchers with a stake in the tool and who might potentially see patients who would need the decision aid/tool? (check one) 
$\square$ No

$\square$ Not reported

$\square$ Unclear

Comments

32. (Display logic: only include if 31 is yes) How many clinician users were consulted in total?

Number :

Total not clear but it was at least this many :

$\square$ Not reported

$\square$ Unclear

Comments

33. (Display logic: only include if 31 is yes) When were clinician users consulted? (check all that apply)

$\square$ Before first prototype was developed

$\square$ After first prototype was developed, but before final prototype was developed

$\square$ After final prototype was developed

$\square$ Not reported

$\square$ Unclear

Comments

34. (Display logic: only include if 31 is yes) Did the developers make any changes to tool based on clinician users' feedback? (check all that apply)

$\square$ Yes

$\square \quad$ No

$\square$ Not reported

$\square$ Unclear

Comments

35. (Display logic: only include if 31 is yes) Were clinician users compensated/incentivized in any way?

$\square$ Yes (check all that apply)

- cash

- gift cards/points

- parking/transportation

o drawings/lottery

o refreshments

o unclear

o other

No, no funds or equivalent exchanged hands in any way

Not reported

Comments

36. Was there an expert panel (panel of academics, clinicians, etc.) involved? (check one)
$\square$ Yes
$\square$ No
$\square$ Not reported
$\square$ Unclear
Not applicable

Comments 
37. Did any users have formal links with specific patient/consumer organization (ex. employee or volunteer within disease-specific patient)?

$\square$ Yes, describe:

$\square$ Yes, describe:

$\square$ Yes, describe:

$\square$ Yes, describe:

$\square$ No/Not reported

$\square$ Unclear

38. Did any users have formal links with specific clinical organization? (e.g. Royal College of Physicians, American Medical Association, American Association of Clinical Radiologists, etc.)

Yes, describe:

Yes, describe:

Yes, describe:

$\square$ Yes, describe:

$\square$ No/Not reported

$\square$ Unclear

39. What other (i.e. other than patients, family and friends, caregivers, surrogates and clinician users) kinds of relevant people were involved? (what they report in article, do not infer, but look for synonyms and flag for discussion at team meeting by adding a comment)

$\square$ Human factors. usability experts

$\square$ Designers (e.g., interaction designers, interface designers, user experience designers, human computer interaction experts, etc.)

$\square$ Graphic designers (e.g. illustrators, data display experts, photographers, videographers)

$\square$ Web/app/system developers

$\square$ Data security experts

$\square$ Plain language, literacy experts

$\square$ Decision experts, decision science experts

$\square$ Experts in counseling

$\square$ Patient education experts

$\square$ Social media experts

$\square$ Online community managers

$\square$ Managers, administrators, and organisational decision-makers

$\square$ Policymakers and planners

$\square$ Communication campaign experts

$\square$ Other

$\square$ Other

$\square$ Other

$\square$ Not reported

$\square$ Not applicable

$\square$ Comments 


\section{Quality appraisal (i.e., can we have confidence in the data?)}

40. Check all sections apply to this article, then answer the subquestions:

(automatically checked) For all studies, check whether the article describes (check all that apply):

$\circ$ Description of the context (clinical context, setting, etc.)

- Description of the purpose of the study

For development studies, check whether the article describes (check all that apply):

- Description of how development occurred (i.e., at least one step described in full, not just, "we developed a decision aid,")

- Description of how content was developed and/or refined

- Description of how format was developed and/or refined

- Description of how data were used to refine tool

Does the article report results relating to human study participants? If yes, check whether the article describes (check all that apply):

- Description of participants (age, gender, clinicial characteristics, etc.)

- Justification of sampling (why they recruited the people they recruited)

- Description of data collection and analysis (what data did they collect and what did they do with it)

- Justification of measurements (e.g., validated measures, standard measures, reasons for choices, etc.) (look for: citations, "validated measure", Cronbach alpha)

For non-experimental evaluation studies, check whether the article describes (check all that apply):

- Control of potentially confounding variables (look for: age, education, literacy, etc.)

For experimental evaluation studies (e.g., randomized controlled studies), check whether the article describes (check all that apply):

- Method of randomization and/or sequence generation

- Allocation concealment and/or blinding (i.e., study participants don't know to which arm they were assigned)

- Reported number of dropouts or complete outcome data

Comments

Quality score $=100 *$ number of checked items/number of possible checked items.

N.B. We will collect this for descriptive reasons but won't set a threshold (yet) because part of the point of this whole review is that we don't know what the best methods are, so things like, "appropriate sampling," are impossible to judge. 


\section{Appendix 3. Full details of data, analyses, and study quality}

(Text in grey and in parentheses gives the variable name in the dataset for readers who wish to further explore the provided data.)

Table S3.1 Theories, models, frameworks, or standards guiding the development process

\begin{tabular}{|l|l|l|}
\hline & $\begin{array}{l}\text { Patient decision aid projects }(\mathrm{n}=325) \\
\mathrm{n}(\%)(\mathrm{da}=1)\end{array}$ & $\begin{array}{l}\text { User-centered design projects }(\mathrm{n}=65) \\
\mathrm{n}(\%)(\mathrm{da}=0)\end{array}$ \\
\hline $\begin{array}{l}\text { No theory/model/framework/standard } \\
\text { reported (Thmofr16) }\end{array}$ & $167(51)$ & $0(0)$ \\
\hline $\begin{array}{l}\text { Other theory/model/framework/standard: } \\
\text { PtDA: social cognitive theory, CREDIBLE } \\
\text { criteria, Janis and Mann conflict model of } \\
\text { decision making; UCD: Bates' model for } \\
\text { information seeking behavior, Human } \\
\text { Factors techniques, Information theory; } \\
\text { Medical Research Council (MRC) } \\
\text { framework, Patient-Clinician-Designer } \\
\text { (PCD) Framework. }\end{array}$ & $67(21)$ & $11(17)$ \\
\hline $\begin{array}{l}\text { International Patient Decision Aids } \\
\text { Standard (IPDAS) }\end{array}$ & $63(19)$ & $0(0)$ \\
\hline $\begin{array}{l}\text { Ottawa Decision Support Framework }{ }^{n e} \\
\text { (Thmofr9) }\end{array}$ & $56(17)$ & $0(0)$ \\
\hline Stages of Change ${ }^{n e}$ (Thmofr12) & $9(3)$ & $1(2)$ \\
\hline $\begin{array}{l}\text { Theory of Planned Behaviour }{ }^{\text {ne }} \\
\text { (Thmofr14) }\end{array}$ & $9(3)$ & $2(3)$ \\
\hline Multiattribute Utility Theory ${ }^{\text {ne }}$ (Thmofr8) & $5(2)$ & $0(0)$ \\
\hline
\end{tabular}




\begin{tabular}{|c|c|c|}
\hline Analytic Hierarchy Process ${ }^{\text {ne }}$ (Thmofr2) & $3(1)$ & $1(2)$ \\
\hline 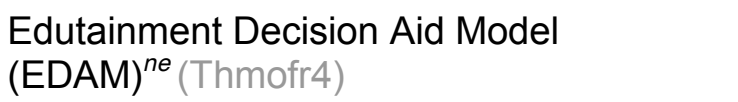 & $3(1)$ & $0(0)$ \\
\hline User-Centered Design ${ }^{\text {ne }}($ Thmofr15) & $2(1)$ & $65(100)$ \\
\hline Elaboration Likelihood Model ${ }^{n e}$ (Thmofr5) & $2(1)$ & $0(0)$ \\
\hline Expected Utility Theory ${ }^{n e}$ (Thmofr6) & $2(1)$ & $0(0)$ \\
\hline $\begin{array}{l}\text { Differentiation and Consolidation Theory }{ }^{\text {ne }} \\
\text { (Thmofr } 3 \text { ) }\end{array}$ & $1(<1)$ & $0(0)$ \\
\hline Fast and Frugal Heuristics ${ }^{n e}$ (Thmofr 7 ) & $1(<1)$ & $0(0)$ \\
\hline Precaution Adoption Model $^{n e}($ Thmofr10) & $1(<1)$ & $0(0)$ \\
\hline Preventive Health Model ${ }^{n e}$ (Thmofr11) & $0(0)$ & $0(0)$ \\
\hline
\end{tabular}

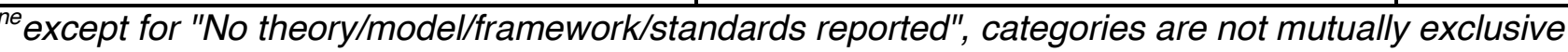

Table S3.2 Tool characteristics

\begin{tabular}{|l|l|l|l|}
\hline & & $\begin{array}{l}\text { Patient decision aid projects } \\
(\mathrm{n}=325) \\
\mathrm{n}(\%)\end{array}$ & $\begin{array}{l}\text { User-centered design projects } \\
(\mathrm{n}=65) \\
\mathrm{n}(\%)\end{array}$ \\
\hline Format of the tool $^{\text {ne }}$ & Paper (Format1) & $198(61)$ & $2(3)$ \\
\hline & Recording (Format2) & $89(27)$ & $0(0)$ \\
\hline & $\begin{array}{l}\text { Requires multiple formats } \\
\text { (Format7) }\end{array}$ & $77(24)$ & $14(22)$ \\
\hline & $\begin{array}{l}\text { Electronic application } \\
\text { (Format10) }\end{array}$ & $72(22)$ & $8(12)$ \\
\hline
\end{tabular}




\begin{tabular}{|c|c|c|c|}
\hline & $\begin{array}{l}\text { Offered in multiple formats } \\
\text { (Format6) }\end{array}$ & $71(22)$ & $6(9)$ \\
\hline & Online application (Format17) & $70(22)$ & $27(42)$ \\
\hline & Conversation (Format3) & $55(17)$ & $3(5)$ \\
\hline & $\begin{array}{l}\text { Paper delivered online } \\
\text { (Format9) }\end{array}$ & $18(6)$ & $0(0)$ \\
\hline & $\begin{array}{l}\text { Other (PtDA: self-examination } \\
\text { tutorial; UCD: virtual } \\
\text { environment, appointment } \\
\text { reminders, assistive device...) } \\
\text { (Format5) }\end{array}$ & $2(1)$ & $23(35)$ \\
\hline & Mobile App (Format11) & $1(<1)$ & $23(35)$ \\
\hline & $\begin{array}{l}\text { Unclear or Not reported } \\
\text { (Format4, Format8) }\end{array}$ & $0(0)$ & $0(0)$ \\
\hline \multirow{5}{*}{$\begin{array}{l}\text { Clinical context addessed by } \\
\text { the tool }{ }^{n e}\end{array}$} & Breast Cancer (Clincon9) & $64(20)$ & $1(2)$ \\
\hline & $\begin{array}{l}\text { Reproductive Health } \\
\text { (Clincon3) }\end{array}$ & $61(19)$ & $1(2)$ \\
\hline & Prostate Cancer (Clincon1) & $47(14)$ & $1(2)$ \\
\hline & $\begin{array}{l}\text { Other: PtDA: Benign prostatic } \\
\text { hyperplasia, smoking, } \\
\text { dementia; UCD: elderly, } \\
\text { dementia (Clincon8) }\end{array}$ & $35(11)$ & $14(22)$ \\
\hline & $\begin{array}{l}\text { Other (Chronic): PtDA: Knee } \\
\text { osteoarthritis, Multiple } \\
\text { sclerosis, osteoporosis; UCD: }\end{array}$ & $35(11)$ & $11(17)$ \\
\hline
\end{tabular}




\begin{tabular}{|l|l|l|l|}
\hline & Obesity (Clincon17) & & \\
\hline & $\begin{array}{l}\text { Cardiovascular Health (Heart } \\
\text { disease, stroke, etc...) } \\
\text { (Clincon15) }\end{array}$ & $29(9)$ & $5(8)$ \\
\hline & Colorectal Cancer (Clincon11) & $26(8)$ & 0 (0) \\
\hline & Ovarian Cancer (Clincon10) & $17(5)$ & 0 (0) \\
\hline & Mental health (Clincon18) & $11(3)$ & $7(11)$ \\
\hline & $\begin{array}{l}\text { Advance Care Planning } \\
\text { (Clincon4) }\end{array}$ & $10(3)$ & 0 (0) \\
\hline & Diabetes (Clincon2) & $8(2)$ & $7(11)$ \\
\hline & $\begin{array}{l}\text { Vaccine-Preventable Disease } \\
\text { (Clincon5) }\end{array}$ & $7(2)$ & $2(3)$ \\
\hline & Lung Cancer (Clincon12) & $7(2)$ & 0 (0) \\
\hline & $\begin{array}{l}\text { Cancer in general, not specific } \\
\text { (Clincon_anycancer) }\end{array}$ & $7(2)$ & $2(3)$ \\
\hline & Disability (Clincon16) & $6(2)$ & $16(25)$ \\
\hline & $\begin{array}{l}\text { Other Cancer: PtDA: cervical } \\
\text { cancer, Ductal carcinoma in } \\
\text { situ (DCIS), melanoma, } \\
\text { Papillary Thyroid Cancer } \\
\text { (Clincon13) }\end{array}$ & $4(1)$ & $0(0)$ \\
\hline & $\begin{array}{l}\text { Chronic Obstructive } \\
\text { Pulmonary Disorder (COPD) } \\
\text { (Clincon14) }\end{array}$ & $2(1)$ & $3(5)$ \\
\hline & & & \\
\hline
\end{tabular}




\begin{tabular}{|l|l|l|l|}
\hline & Not reported (Clincon6) & $0(0)$ & $1(2)$ \\
\hline $\begin{array}{l}\text { Type of decision or health } \\
\text { issue addressed by the tool }\end{array}$ & Treatment (Typdec5) & $184(57)$ & $7(11)$ \\
\hline & Screening (Typdec3) & $68(21)$ & $1(2)$ \\
\hline & Prevention (Typdec1) & $38(12)$ & $5(8)$ \\
\hline & Genetic Testing (Typdec2) & $20(6)$ & $0(0)$ \\
\hline & $\begin{array}{l}\text { Other: PtDA: clinical trial } \\
\text { participation, Smoking } \\
\text { cessation; UCD: monitoring, } \\
\text { self-management, self- } \\
\text { monitoring... (Typdec9) }\end{array}$ & $16(5)$ & $26(40)$ \\
\hline & Diagnostic Testing (Typdec4) & $12(4)$ & $0(0)$ \\
\hline & $\begin{array}{l}\text { Management (therapeutic, } \\
\text { risk...) (Typdec10) }\end{array}$ & $9(3)$ & $8(12)$ \\
\hline & $\begin{array}{l}\text { Dealing with barriers in one's } \\
\text { everyday life (Typdec6) }\end{array}$ & $4(1)$ & $29(45)$ \\
\hline & Unclear (Typdec8) & $2(1)$ & $0(0)$ \\
\hline Context of tool usage ${ }^{\text {ne }}$ & Not reported (Typdec7) & $1(<1)$ & $0(0)$ \\
\hline & $\begin{array}{l}\text { At home or in a private setting } \\
\text { (Contex1) }\end{array}$ & $148(46)$ & $16(25)$ \\
\hline & $\begin{array}{l}\text { During an in-person clinical } \\
\text { encounter (Contex3) }\end{array}$ & $102(31)$ & $4(6)$ \\
\hline & $\begin{array}{l}\text { In a health care setting but not } \\
\text { during a clinical encounter }\end{array}$ & $93(29)$ & $1(2)$ \\
\hline & & & \\
\hline
\end{tabular}




\begin{tabular}{|l|l|l|l|}
\hline & (Contex2) & & \\
\hline & Not reported (Contex5) & $40(12)$ & $3(5)$ \\
\hline & Unclear (Contex7) & $20(6)$ & $4(6)$ \\
\hline & $\begin{array}{l}\text { Other: PtDA: at school, } \\
\text { training } \\
\text { (Contex4) at school }\end{array}$ & $7(2)$ & $3(5)$ \\
\hline & Daily life (Contex6) & $3(1)$ & $44(68)$ \\
\hline & $\begin{array}{l}\text { During a virtual clinical } \\
\text { encounter (Contex8) }\end{array}$ & $2(1)$ & $0(0)$ \\
\hline & $\begin{array}{l}\text { Before clinical encounter } \\
\text { (Timing1) }\end{array}$ & $124(38)$ & $3(5)$ \\
\hline & $\begin{array}{l}\text { During clinical encounter } \\
\text { (Timing2) }\end{array}$ & $102(31)$ & $4(6)$ \\
\hline & $\begin{array}{l}\text { Between clinical encounters } \\
\text { (Timing4) }\end{array}$ & $75(23)$ & $1(2)$ \\
\hline & Not reported (Timing7) & $46(14)$ & $9(14)$ \\
\hline & Unclear (Timing3) & $24(7)$ & $7(11)$ \\
\hline & Other (Timing6) & $14(4)$ & $6(9)$ \\
\hline & $\begin{array}{l}\text { After clinical encounter } \\
\text { (Timing8) }\end{array}$ & $12(4)$ & $2(3)$ \\
\hline & $\begin{array}{l}\text { Not associated with clinical } \\
\text { encounter (Timing5) }\end{array}$ & $9(3)$ & $22(34)$ \\
\hline & Everyday life (Timing9) & $1(<1)$ & $16(25)$ \\
\hline
\end{tabular}




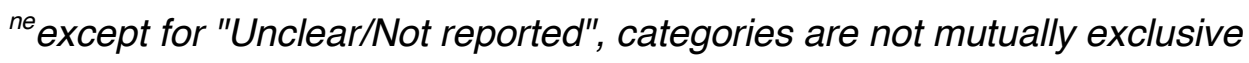

Table S3.3 Iteration

\begin{tabular}{|l|l|l|}
\hline & $\begin{array}{l}\text { Patient decision aid projects with } \\
\text { development data }(\mathrm{n}=283) \\
\mathrm{n}(\%)\end{array}$ & $\begin{array}{l}\text { User-centered design projects with } \\
\text { development data }(\mathrm{n}=65) \\
\mathrm{n}(\%)\end{array}$ \\
\hline Development was iterative (iterative) & $210(74)$ & $60(92)$ \\
\hline $\begin{array}{l}\text { Number of cycles when iterative: Median } \\
(\text { IQR) (Range) (Itcycles_nb) }\end{array}$ & $3(2-4)(1-50)$ & $3(2-3)(1-33)$ \\
\hline $\begin{array}{l}\text { Description of changes between } \\
\text { versions/prototypes (Itchnges) }\end{array}$ & $64(23)$ & $34(52)$ \\
\hline
\end{tabular}

Table S3.4 Clinician users' involvement

\begin{tabular}{|l|l|l|l|l|l|}
\hline & & $\begin{array}{l}\text { Patient decision aid } \\
\text { projects (n=325) } \\
\mathrm{n}(\%)\end{array}$ & $\begin{array}{l}\text { User-centered } \\
\text { design projects } \\
(\mathrm{n}=65) \\
\mathrm{n}(\%)\end{array}$ & $\begin{array}{l}\text { Patient decision aid } \\
\text { projects (n=325) } \\
\text { Median (IQR) } \\
\text { (Range) }\end{array}$ & $\begin{array}{l}\text { User-centered } \\
\text { design projects } \\
(\mathrm{n}=65) \\
\text { Median (IQR) } \\
(\text { Range) }\end{array}$ \\
\hline $\begin{array}{l}\text { Clinician were } \\
\text { consulted by the } \\
\text { research team }\end{array}$
\end{tabular}




\begin{tabular}{|c|c|c|c|c|c|}
\hline & Unclear (clins_un) & $4(1)$ & $0(0)$ & & \\
\hline & Total & $325(100)$ & $65(100)$ & & \\
\hline \multirow{5}{*}{$\begin{array}{l}\text { When clinicians } \\
\text { involved ( } \mathrm{n}=205, \\
\mathrm{n}=36), \text { total number } \\
\text { involved }^{e}\end{array}$} & $\begin{array}{l}\text { Total was clear } \\
\text { (Clinstot_1, } \\
\text { Clinstot_nb) }\end{array}$ & $47(23)$ & $8(22)$ & $13(5-26)(2-1280)$ & $14(7-37)(3-102)$ \\
\hline & $\begin{array}{l}\text { Total was not clear, } \\
\text { but it was at least } \\
\text { this many } \\
\text { (Clinstot_2, } \\
\text { Clinstot_nb) }\end{array}$ & $46(22)$ & $10(28)$ & $9(5-16)(1-143)$ & $7(3-15)(2-20)$ \\
\hline & $\begin{array}{l}\text { Not reported } \\
\text { (Clinstot_3) }\end{array}$ & $99(48)$ & $17(47)$ & & \\
\hline & Unclear (Clinstot_4) & $13(6)$ & $1(3)$ & & \\
\hline & Total & $205(100)$ & $36(100)$ & $10(5-22)(1-1280)$ & $9(4-20)(2-102)$ \\
\hline \multirow[t]{5}{*}{$\begin{array}{l}\text { When clinicians } \\
\text { involved ( } \mathrm{n}=205 \text {, } \\
\mathrm{n}=36 \text { ), timing of } \\
\text { consultation }^{n e}\end{array}$} & $\begin{array}{l}\text { Before initial } \\
\text { prototype } \\
\text { developed } \\
\text { (Clinsbef) }\end{array}$ & $131(64)$ & $23(64)$ & & \\
\hline & $\begin{array}{l}\text { Between initial and } \\
\text { final prototypes } \\
\text { (Clinsbtw) }\end{array}$ & $141(69)$ & $19(53)$ & & \\
\hline & $\begin{array}{l}\text { After final prototype } \\
\text { developed (Clinsaft) }\end{array}$ & $38(19)$ & $0(0)$ & & \\
\hline & Unclear (Clinsun) & $4(2)$ & $1(3)$ & & \\
\hline & Not reported & $14(7)$ & $3(8)$ & & \\
\hline
\end{tabular}




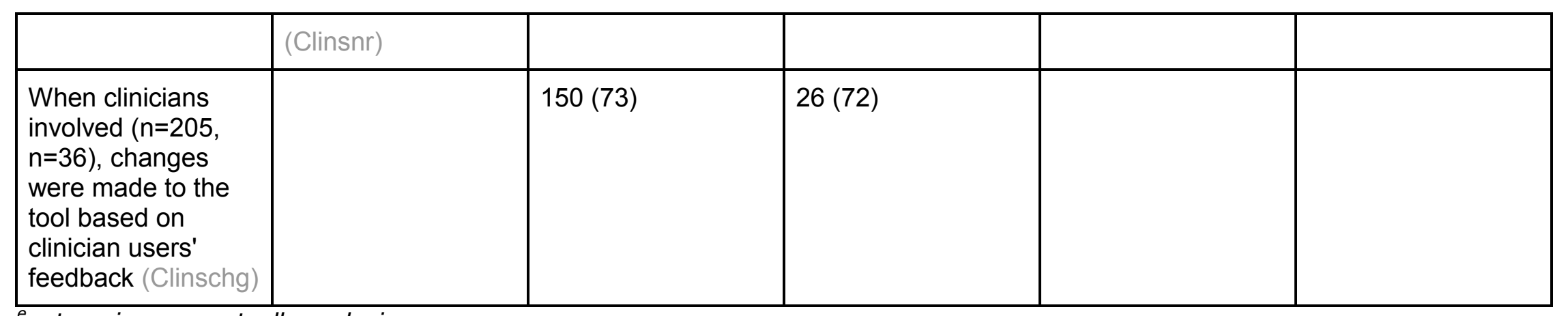

${ }^{e}$ categories are mutually exclusive

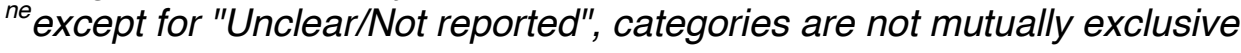

Table S3.5 User characteristics

\begin{tabular}{|l|l|l|l|}
\hline & & $\begin{array}{l}\text { Patient decision aid projects } \\
(\mathrm{n}=325) \\
\mathrm{n}(\%)\end{array}$ & $\begin{array}{l}\text { User-centered design projects } \\
(\mathrm{n}=65) \\
\mathrm{n}(\%)\end{array}$ \\
\hline $\begin{array}{l}\text { Patients, members of the } \\
\text { public were involved }\end{array}$ & $\begin{array}{l}\text { Any patients or members of } \\
\text { the public (kuinvp) }\end{array}$ & $310(95)$ & $64(98)$ \\
\hline & $\begin{array}{l}\text { Faced this situation in the past } \\
\text { (kuinvp_past) }\end{array}$ & $70(22)$ & $4(6)$ \\
\hline & $\begin{array}{l}\text { Are currently facing this } \\
\text { situation (kuinvp_now) }\end{array}$ & $275(85)$ & $61(94)$ \\
\hline & $\begin{array}{l}\text { Might face this situation in the } \\
\text { future (kuinvp_fut) }\end{array}$ & $82(25)$ & $9(14)$ \\
\hline & $\begin{array}{l}\text { Have not and will not face this } \\
\text { situation (kuinv_nev) }\end{array}$ & $0(0)$ & $3(5)$ \\
\hline & $\begin{array}{l}\text { Not reported / Unclear } \\
\text { (kuinvp_nrun) }\end{array}$ & $3(1)$ & $2(3)$ \\
\hline
\end{tabular}




\begin{tabular}{|c|c|c|c|}
\hline $\begin{array}{l}\text { Family members/Friends were } \\
\text { involved }\end{array}$ & $\begin{array}{l}\text { Any family members or friends } \\
\text { (kuinvfmf) }\end{array}$ & 35 (11) & $13(20)$ \\
\hline & $\begin{array}{l}\text { Faced this situation in the past } \\
\text { (kuinvfmf_past) }\end{array}$ & $5(2)$ & $0(0)$ \\
\hline & $\begin{array}{l}\text { Are currently facing this } \\
\text { situation (kuinvfmf_now) }\end{array}$ & $30(9)$ & $13(20)$ \\
\hline & $\begin{array}{l}\text { Might face this situation in the } \\
\text { future (kuinvfmf_fut) }\end{array}$ & $5(2)$ & $0(0)$ \\
\hline & $\begin{array}{l}\text { Have not and will not face this } \\
\text { situation (kuinvfmf_nev) }\end{array}$ & $0(0)$ & $0(0)$ \\
\hline & $\begin{array}{l}\text { Not reported / Unclear } \\
\text { (kuinvfmf_nrun) }\end{array}$ & $0(0)$ & $0(0)$ \\
\hline \multirow[t]{6}{*}{ Caregivers were involved ${ }^{\text {ne }}$} & Any caregivers (kuinvcar) & $15(5)$ & $14(22)$ \\
\hline & $\begin{array}{l}\text { Faced this situation in the past } \\
\text { (kuinvcar_past) }\end{array}$ & $1(<1)$ & $0(0)$ \\
\hline & $\begin{array}{l}\text { Are currently facing this } \\
\text { situation (kuinvcar_now) }\end{array}$ & $13(4)$ & $14(22)$ \\
\hline & $\begin{array}{l}\text { Might face this situation in the } \\
\text { future (kuinvcar_fut) }\end{array}$ & $2(1)$ & $1(2)$ \\
\hline & $\begin{array}{l}\text { Have not and will not face this } \\
\text { situation (kuinvcar_nev) }\end{array}$ & $0(0)$ & $0(0)$ \\
\hline & $\begin{array}{l}\text { Not reported / Unclear } \\
\text { (kuinvcar_nrun) }\end{array}$ & $0(0)$ & $0(0)$ \\
\hline $\begin{array}{l}\text { Surrogate decision-makers } \\
\text { were involved }\end{array}$ & $\begin{array}{l}\text { Any surrogate decision-makers } \\
\text { (kuinvsur) }\end{array}$ & $8(2)$ & $0(0)$ \\
\hline
\end{tabular}




\begin{tabular}{|l|l|l|l|}
\hline & $\begin{array}{l}\text { Faced this situation in the past } \\
\text { (kuinvsur_past) }\end{array}$ & $2(1)$ & $0(0)$ \\
\hline & $\begin{array}{l}\text { Are currently facing this } \\
\text { situation (kuinvsur_now) }\end{array}$ & $6(2)$ & $0(0)$ \\
\hline & $\begin{array}{l}\text { Might face this situation in the } \\
\text { future (kuinvsur_fut) }\end{array}$ & $2(1)$ & $0(0)$ \\
\hline & $\begin{array}{l}\text { Have not and will not face this } \\
\text { situation (kuinvsur_nev) }\end{array}$ & $0(0)$ & $0(0)$ \\
\hline & $\begin{array}{l}\text { Not reported / Unclear } \\
\text { (kuinvsur_nrun) }\end{array}$ & $0(0)$ & $0(0)$ \\
\hline
\end{tabular}

except for "Not reported/Unclear", categories are not mutually exclusive

Table S3.6 Reporting of users' sociodemographic characteristics

\begin{tabular}{|c|c|c|c|}
\hline & & $\begin{array}{l}\text { Patient decision aid projects } \\
(n=325) \\
n(\%)\end{array}$ & $\begin{array}{l}\text { User-centered design projects } \\
(n=65) \\
n(\%)\end{array}$ \\
\hline \multirow[t]{3}{*}{ Age } & Yes $^{e}$ (charage_y) & $284(87)$ & $45(69)$ \\
\hline & Not reported ${ }^{e}$ (charage_nr) & $39(12)$ & $20(31)$ \\
\hline & Unclear $^{e}$ (charage_un) & $2(1)$ & $0(0)$ \\
\hline \multirow[t]{3}{*}{ Sex/Gender } & Yes $^{e}$ (chargen_y) & $287(88)$ & $41(63)$ \\
\hline & Not reported ${ }^{e}$ (chargen_nr) & $36(11)$ & $24(37)$ \\
\hline & Unclear $^{e}$ (chargen_un) & $2(1)$ & $0(0)$ \\
\hline Race/Ethnicity & Yes $^{e}$ (charetn_y) & $144(44)$ & $11(17)$ \\
\hline
\end{tabular}




\begin{tabular}{|c|c|c|c|}
\hline & Not reported ${ }^{e}$ (charetn_nr) & $178(55)$ & $54(83)$ \\
\hline & Unclear $^{e}$ (charetn_un) & $3(1)$ & $0(0)$ \\
\hline \multirow[t]{3}{*}{ Education } & Yes $^{e}$ (charedu_y) & $227(70)$ & $19(29)$ \\
\hline & Not reported ${ }^{e}$ (charedu_nr) & $94(29)$ & $46(71)$ \\
\hline & Unclear $^{e}$ (charedu_un) & $4(1)$ & $0(0)$ \\
\hline \multirow[t]{3}{*}{ Income } & Yes $^{e}$ (charinc_y) & $58(18)$ & $5(8)$ \\
\hline & Not reported ${ }^{e}$ (charinc_nr) & $264(81)$ & $60(92)$ \\
\hline & Unclear $^{e}$ (charinc_un) & $3(1)$ & $0(0)$ \\
\hline \multirow[t]{3}{*}{ Literacy/Health literacy } & Yes $^{e}$ (charlit_y) & $21(6)$ & $4(6)$ \\
\hline & Not reported ${ }^{e}$ (charlit_nr) & $304(94)$ & $61(94)$ \\
\hline & Unclear ${ }^{e}$ (charlit_un) & $0(0)$ & $0(0)$ \\
\hline \multirow[t]{3}{*}{ Numeracy } & Yes $^{e}$ (charnum_y) & $7(2)$ & $2(3)$ \\
\hline & Not reported ${ }^{e}$ (charnum_nr) & $317(98)$ & $63(97)$ \\
\hline & Unclear $^{e}$ (charnum_un) & $1(<1)$ & $0(0)$ \\
\hline \multirow[t]{3}{*}{ Clinical characteristics } & Yes $^{e}$ (charclin_y) & $258(79)$ & $34(52)$ \\
\hline & Not reported ${ }^{e}$ (charclin_nr) & $65(20)$ & $31(48)$ \\
\hline & Unclear ${ }^{e}$ (charclin_un) & $2(1)$ & $0(0)$ \\
\hline
\end{tabular}

${ }^{e}$ categories are mutually exclusive 
Table S3.7 Type and level of user involvement

\begin{tabular}{|c|c|c|c|}
\hline & & $\begin{array}{l}\text { Patient decision aid projects } \\
\text { with development data }(n=283) \\
n(\%)\end{array}$ & $\begin{array}{l}\text { User-centered design projects } \\
\text { with development data }(\mathrm{n}=65) \\
\mathrm{n}(\%)\end{array}$ \\
\hline \multirow[t]{4}{*}{ Literature review } & \begin{tabular}{|l} 
Individuallye \\
(pfcsinvmod_lit_in)
\end{tabular} & $0(0)$ & $0(0)$ \\
\hline & In group ${ }^{e}$ (pfcsinvmod_lit_fg) & $0(0)$ & $0(0)$ \\
\hline & Both $^{e}$ (pfcsinvmod_lit_both) & $0(0)$ & $0(0)$ \\
\hline & Other ${ }^{e}$ (pfcsinvmod_lit_other) & $0(0)$ & $0(0)$ \\
\hline \multirow[t]{4}{*}{$\begin{array}{l}\text { Observation of existing } \\
\text { processes }\end{array}$} & $\begin{array}{l}\text { Individually } \\
\text { (pfcsinvmod_obs_in) }\end{array}$ & $10(4)$ & $18(28)$ \\
\hline & In group $^{e}$ (pfcsinvmod_obs_fg) & $2(1)$ & $2(3)$ \\
\hline & Both $^{e}$ (pfcsinvmod_obs_both) & $2(1)$ & $2(3)$ \\
\hline & $\begin{array}{l}\text { Othere } \\
\text { (pfcsinvmod_obs_other) }\end{array}$ & $0(0)$ & $1(2)$ \\
\hline \multirow[t]{4}{*}{ Formal needs assessment } & $\begin{array}{l}\text { Individually }{ }^{e} \\
\text { (pfcsinvmod_fna_in) }\end{array}$ & $12(4)$ & $11(17)$ \\
\hline & In group $^{e}$ (pfcsinvmod_fna_fg) & $10(4)$ & $3(5)$ \\
\hline & Both $^{e}$ (pfcsinvmod_fna_both) & $7(2)$ & $5(8)$ \\
\hline & Other ${ }^{e}$ (pfcsinvmod_fna_other) & $0(0)$ & $0(0)$ \\
\hline \multirow[t]{2}{*}{ Informal needs assessment } & $\begin{array}{l}\text { Individuallye } \\
\text { (pfcsinvmod_ina_in) }\end{array}$ & $39(14)$ & $11(17)$ \\
\hline & In group ${ }^{e}$ (pfcsinvmod_ina_fg) & $28(10)$ & $15(23)$ \\
\hline
\end{tabular}




\begin{tabular}{|c|c|c|c|}
\hline & Both $^{e}$ (pfcsinvmod_ina_both) & $25(9)$ & $11(17)$ \\
\hline & Other ${ }^{e}$ (pfcsinvmod_ina_other) & $0(0)$ & $0(0)$ \\
\hline \multirow[t]{4}{*}{$\begin{array}{l}\text { Develop and/or validate } \\
\text { underlying model }\end{array}$} & $\begin{array}{l}\text { Individuallye } \\
\text { (pfcsinvmod_mod_in) }\end{array}$ & $0(0)$ & $0(0)$ \\
\hline & \begin{tabular}{|l|} 
In group $^{e}$ \\
(pfcsinvmod_mod_fg)
\end{tabular} & $0(0)$ & $0(0)$ \\
\hline & Both ${ }^{e}$ (pfcsinvmod_mod_both) & $0(0)$ & $0(0)$ \\
\hline & $\begin{array}{l}\text { Other }{ }^{e} \\
\text { (pfcsinvmod_mod_other) }\end{array}$ & $0(0)$ & $0(0)$ \\
\hline \multirow[t]{4}{*}{ Storyboarding / wireframing } & $\begin{array}{l}\text { Individuallye } \\
\text { (pfcsinvmod_sto_in) }\end{array}$ & $4(1)$ & $2(3)$ \\
\hline & In group ${ }^{e}$ (pfcsinvmod_sto_fg) & $1(<1)$ & $4(6)$ \\
\hline & Both ${ }^{e}$ (pfcsinvmod_sto_both) & $1(<1)$ & $2(3)$ \\
\hline & Other $^{e}$ (pfcsinvmod_sto_other) & $0(0)$ & $0(0)$ \\
\hline \multirow[t]{4}{*}{ Adapt/translate tool } & \begin{tabular}{|l} 
Individually \\
(pfcsinvmod_ada_in)
\end{tabular} & $1(<1)$ & $0(0)$ \\
\hline & In group $^{e}$ (pfcsinvmod_ada_fg) & $1(<1)$ & $0(0)$ \\
\hline & Both $^{e}$ (pfcsinvmod_ada_both) & $0(0)$ & $0(0)$ \\
\hline & $\begin{array}{l}\text { Othere } \\
\text { (pfcsinvmod_ada_other) }\end{array}$ & $0(0)$ & $0(0)$ \\
\hline \multirow[t]{2}{*}{ Content/format review prior } & $\begin{array}{l}\text { Individuallye } \\
\text { (pfcsinvmod_crp_in) }\end{array}$ & $6(2)$ & $2(3)$ \\
\hline & In group ${ }^{e}$ (pfcsinvmod_crp_fg) & $16(6)$ & $8(12)$ \\
\hline
\end{tabular}




\begin{tabular}{|c|c|c|c|}
\hline & Both $^{e}$ (pfcsinvmod_crp_both) & $6(2)$ & $3(5)$ \\
\hline & Other ${ }^{e}$ (pfcsinvmod_crp_other) & $0(0)$ & $0(0)$ \\
\hline \multirow[t]{4}{*}{ Prototype development } & $\begin{array}{l}\text { Individually }{ }^{e} \\
\text { (pfcsinvmod_prot_in) }\end{array}$ & $17(6)$ & $1(2)$ \\
\hline & In group $^{e}$ (pfcsinvmod_prot_fg) & $11(4)$ & $2(3)$ \\
\hline & Both $^{e}$ (pfcsinvmod_prot_both) & $1(<1)$ & $4(6)$ \\
\hline & $\begin{array}{l}\text { Othere } \\
\text { (pfcsinvmod_prot_other) }\end{array}$ & $3(1)$ & $0(0)$ \\
\hline \multirow[t]{4}{*}{ Content/format review after } & $\begin{array}{l}\text { Individuallye } \\
\text { (pfcsinvmod_cra_in) }\end{array}$ & $27(10)$ & $10(15)$ \\
\hline & In group ${ }^{e}$ (pfcsinvmod_cra_fg) & $30(11)$ & $8(12)$ \\
\hline & Both $^{e}$ (pfcsinvmod_cra_both) & $13(5)$ & $1(2)$ \\
\hline & Other $^{e}$ (pfcsinvmod_cra_other) & $1(<1)$ & $0(0)$ \\
\hline \multirow[t]{4}{*}{ Pilot/usability testing } & $\begin{array}{l}\text { Individually }^{e} \\
\text { (pfcsinvmod_pil_in) }\end{array}$ & $141(50)$ & $43(66)$ \\
\hline & In group ${ }^{e}$ (pfcsinvmod_pil_fg) & $8(3)$ & $5(8)$ \\
\hline & Both $^{e}$ (pfcsinvmod_pil_both) & $11(4)$ & $2(3)$ \\
\hline & Other ${ }^{e}$ (pfcsinvmod_pil_other) & $0(0)$ & $0(0)$ \\
\hline \multirow[t]{2}{*}{$\begin{array}{l}\text { Second round of pilot/usability } \\
\text { testing }\end{array}$} & $\begin{array}{l}\text { Individually } \\
\text { (pfcsinvmod_pilot2_in) }\end{array}$ & $25(9)$ & $11(17)$ \\
\hline & $\begin{array}{l}\text { In group } \\
\text { (pfcsinvmod_pilot2_fg) }\end{array}$ & $0(0)$ & $0(0)$ \\
\hline
\end{tabular}




\begin{tabular}{|l|l|l|l|}
\hline & $\begin{array}{l}\text { Both }^{e} \\
\text { (pfcsinvmod_pilot2_both) }\end{array}$ & $0(0)$ & $0(0)$ \\
\hline & $\begin{array}{l}\text { Other } \\
\text { (pfcsinvmod_pilot2_other) }\end{array}$ & $0(0)$ & $0(0)$ \\
\hline
\end{tabular}

${ }^{e}$ categories are mutually exclusive

Table S3.8 Type of user involvement

\begin{tabular}{|c|c|c|}
\hline & $\begin{array}{l}\text { Patient decision aid projects with } \\
\text { development data }(n=283) \\
n(\%)\end{array}$ & $\begin{array}{l}\text { User-centered design projects with } \\
\text { development data }(n=65) \\
n(\%)\end{array}$ \\
\hline $\begin{array}{l}\text { PFCS users involved as participants in } \\
\text { study }^{\text {ne (pfcspts) }}\end{array}$ & $282(>99)$ & $63(97)$ \\
\hline $\begin{array}{l}\text { PFCS users involved in advisory } \\
\text { capacity }^{n e} \text { (pfcsadv) }\end{array}$ & $77(27)$ & $14(22)$ \\
\hline PFCS advisory panel ${ }^{n e}$ (pfcsadvpan) & $26(9)$ & $4(6)$ \\
\hline $\begin{array}{l}\text { PFCS users involved on } \\
\text { research/development team }{ }^{\text {ne }} \text { (pfcsres) }\end{array}$ & $23(8)$ & $9(14)$ \\
\hline Other $^{n e}($ pfcs23_2, pfcs23_5, pfcs23_6) & $0(0)$ & $0(0)$ \\
\hline $\begin{array}{l}\text { Not reported or unclear (pfcs23_7, } \\
\text { pfcs23_8) }\end{array}$ & $0(0)$ & $2(3)$ \\
\hline
\end{tabular}

PFCS users = Patients/public, family members/friends, caregivers, surrogate users

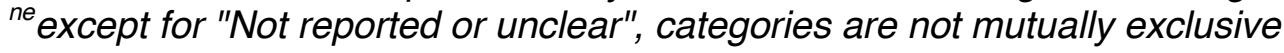

Table S3.9 Methods of eliciting users' responses to the tool

\begin{tabular}{|l|l|l|l|}
\hline & & $\begin{array}{l}\text { Patient decision aid projects } \\
\text { with development data }(\mathrm{n}=283)\end{array}$ & $\begin{array}{l}\text { User-centered design projects } \\
\text { with development data }(\mathrm{n}=65)\end{array}$ \\
\hline
\end{tabular}




\begin{tabular}{|l|l|l|l|}
\hline & & $\mathrm{n}(\%)$ & $\mathrm{n}(\%)$ \\
\hline $\begin{array}{l}\text { Asked thoughts \& opinions of } \\
\text { the tool }^{n e}\end{array}$ & PFCS users (askpfcs) & $211(75)$ & $61(94)$ \\
\hline & Clinician users (askclin) & $118(42)$ & $21(32)$ \\
\hline & Non-users (asknon) & $56(20)$ & $24(37)$ \\
\hline $\begin{array}{l}\text { Observed interacting with the } \\
\text { tool }^{\text {ee }}\end{array}$ & PFCS users (obspfcs) & $117(41)$ & $47(72)$ \\
\hline & Clinician users (obsclin) & $16(6)$ & $2(3)$ \\
\hline & Non-users (obsnon) & $3(1)$ & $3(5)$ \\
\hline Assessed impact on ${ }^{n e}$ & PFCS users (asspfcs) & $248(88)$ & $29(45)$ \\
\hline & Clinician users (assclin) & $22(8)$ & $2(3)$ \\
\hline & Non-users (assnon) & $1(<1)$ & $0(0)$ \\
\hline
\end{tabular}

categories are not mutually exclusive

\section{Table S3.10 Evaluation}

\begin{tabular}{|l|l|l|}
\hline & $\begin{array}{l}\text { Patient decision aid projects }(\mathrm{n}=325) \\
\mathrm{n}(\%)\end{array}$ & $\begin{array}{l}\text { User-centered design projects }(\mathrm{n}=65) \\
\mathrm{n}(\%)\end{array}$ \\
\hline $\begin{array}{l}\text { Evaluation of feasibility, acceptability, } \\
\text { satisfaction with tool/decision aid, } \\
\text { usability, other preliminary metric of } \\
\text { evaluation }\end{array}$ & $216(66)$ & $58(89)$ \\
\hline Evaluation of efficacy ${ }^{n e}\left(\mathrm{eval}^{\text {2) }}\right)$ & $288(89)$ & $29(45)$ \\
\hline Evaluation of implementation $^{\text {ne }}(\mathrm{eval3})$ & $28(9)$ & $8(12)$ \\
\hline
\end{tabular}


${ }^{\text {ne }}$ categories are not mutually exclusive

Table S3.11 Advisory panels and organizations' involvement

\begin{tabular}{|l|l|l|l|}
\hline & & $\begin{array}{l}\text { Patient decision aid projects } \\
(\mathrm{n=325}) \\
\mathrm{n}(\%)\end{array}$ & $\begin{array}{l}\text { User-centered design projects } \\
(\mathrm{n}=65) \\
\mathrm{n}(\%)\end{array}$ \\
\hline $\begin{array}{l}\text { Formal involved organizations } \\
(\text { at least one) }\end{array}$ & $\begin{array}{l}\text { Formal links with specific } \\
\text { patient/consumer organization } \\
\text { (linkorgapt, linkorgapt2, } \\
\text { linkorgapt3, linkorgapt4) }\end{array}$ & $38(12)$ & $9(14)$ \\
\hline $\begin{array}{l}\text { Formal links with specific } \\
\text { clinical organization } \\
\text { (linkorgaclin1, linkorgaclin2, } \\
\text { linkorgaclin3, linkorgaclin4) }\end{array}$ & $8(2)$ & $1(2)$ \\
\hline academics, clinicians, etc.) & $\begin{array}{l}\text { Yes }{ }^{\mathrm{e}} \text { (exptpan_y) } \\
\text { Nort panel (panel of }\end{array}$ & $153(47)$ & $25(38)$ \\
\hline Not reported (exptpan_nr) & $114(35)$ & $2(3)$ \\
\hline & Unclear (exptpan_un) & $8(2)$ & $35(54)$ \\
\hline Not applicable (evaluation & $42(13)$ & $3(5)$ \\
\hline
\end{tabular}

${ }^{n e}$ categories are not mutually exclusive

${ }^{e}$ categories are mutually exclusive

Table S3.12 Patients/public, family members/friends, caregivers, surrogate users' recruitment

\begin{tabular}{|l|l|l|}
\hline & $\begin{array}{l}\text { Patient decision aid projects }(n=325) \\
n(\%)\end{array}$ & $\begin{array}{l}\text { User-centered design projects }(n=65) \\
n(\%)\end{array}$ \\
\hline
\end{tabular}




\begin{tabular}{|c|c|c|}
\hline Convenience sample $^{\text {ne }}$ (recconc) & $266(82)$ & $36(55)$ \\
\hline Community groups $^{\text {ne }}$ (reccomm) & $40(12)$ & $9(14)$ \\
\hline Registries $^{\text {ne }}$ (recreg) & $37(11)$ & $0(0)$ \\
\hline Advertisement $^{\text {te }}$ (recadv) & $35(11)$ & $0(0)$ \\
\hline Flyers, posters ${ }^{\text {ne }}$ (recfly) & $31(10)$ & $4(6)$ \\
\hline $\begin{array}{l}\text { Other type of recruitment: PtDA: Letters, } \\
\text { consecutive sample, telephone, health } \\
\text { insurance; UCD: schools, Daycare } \\
\text { facitlities }^{\text {ne }} \text { (recother) }\end{array}$ & $30(9)$ & $3(5)$ \\
\hline Not reported (recnr) & $15(5)$ & $21(32)$ \\
\hline Online panel ${ }^{\text {ne }}($ recpanel $)$ & $11(3)$ & $0(0)$ \\
\hline Purposive $^{\text {ne }}$ (recpurp) & $10(3)$ & $7(11)$ \\
\hline Snowball sampling ${ }^{\text {ne }}$ (recsnow) & $9(3)$ & $5(8)$ \\
\hline Random sample $^{\text {ne }}$ (recrand) & $8(2)$ & $0(0)$ \\
\hline Unclear (recun) & $2(1)$ & $0(0)$ \\
\hline
\end{tabular}

${ }^{n e}$ except for "Not reported/Unclear", categories are not mutually exclusive

Table S3.13 Patients/public, family members/friends, caregivers, surrogate users' compensation

\begin{tabular}{|l|l|l|}
\hline & $\begin{array}{l}\text { Patient decision aid projects }(\mathrm{n}=325) \\
\mathrm{n}(\%)\end{array}$ & $\begin{array}{l}\text { User-centered design projects }(\mathrm{n}=65) \\
\mathrm{n}(\%)\end{array}$ \\
\hline Any kind of compensation ${ }^{\text {ne }}(\mathrm{comp})$ & $89(27)$ & $17(26)$ \\
\hline Cash $^{\text {ne }}($ Compcash $)$ & $61(19)$ & $8(12)$ \\
\hline
\end{tabular}




\begin{tabular}{|l|l|l|}
\hline Gift cards/points $^{\text {ne }}$ (Compcards) & $29(9)$ & $3(5)$ \\
\hline Parking/transportation ${ }^{\text {ne }}$ (Comppark) & $15(5)$ & $4(6)$ \\
\hline Refreshments $^{\text {ne }}$ (Comprefresh) & $11(3)$ & $1(2)$ \\
\hline $\begin{array}{l}\text { Other kind of compensation: PtDA: 1- } \\
\text { month access to the decision support, } \\
\begin{array}{l}\text { Gift, Small incentives (e.g. key ring } \\
\text { flashlights), Telephone-administered GC } \\
\text { and BRCA1/2 testing; UCD: } \\
\text { Complimentary registration for The } \\
\text { Cooper Institute's Active Living Every Day } \\
\text { program }\end{array}\end{array}$ & $4(1)$ & $3(5)$ \\
\hline Drawings/Lottery & & \\
\hline Unclear (Compother) & $4(1)$ & $0(0)$ \\
\hline
\end{tabular}

PFCS users = Patients/public, family members/friends, caregivers, surrogate users

${ }^{n e}$ except for "Unclear", categories are not mutually exclusive

Table S3.14 Clinician users' compensation when clinician users were involved

\begin{tabular}{|c|c|c|}
\hline & $\begin{array}{l}\text { Patient decision aid projects }(n=325) \\
n(\%)\end{array}$ & $\begin{array}{l}\text { User-centered design projects }(\mathrm{n}=65) \\
\mathrm{n}(\%)\end{array}$ \\
\hline Yes $^{\mathrm{e}}$ (clinscomp_y) & $13(4)$ & $3(5)$ \\
\hline $\operatorname{Cash}^{\text {ne }}($ Clinscomp_1) & $8(2)$ & $2(3)$ \\
\hline Gift cards/points $^{\text {ne }}$ (Clinscomp_2) & $2(1)$ & $0(0)$ \\
\hline Refreshments $^{\text {ne }}$ (Clinscomp_5) & $2(1)$ & $0(0)$ \\
\hline Parking/transportation ${ }^{\text {ne }}$ (Clinscomp_3) & $1(<1)$ & $0(0)$ \\
\hline
\end{tabular}




\begin{tabular}{|c|c|c|}
\hline Unclear (Clinscomp_7) & $1(<1)$ & $1(2)$ \\
\hline Drawings/lottery $^{\text {ne }}$ (Clinscomp_4) & $0(0)$ & $0(0)$ \\
\hline Other $^{\text {ne }}$ (Clinscomp_6) & $0(0)$ & $0(0)$ \\
\hline $\begin{array}{l}\text { No, no funds or equivalent exchanged } \\
\text { hands in any way }{ }^{\mathrm{e}} \text { (clinscomp_n) }\end{array}$ & $0(0)$ & $0(0)$ \\
\hline Not reported ${ }^{\mathrm{e}}$ (clinscomp_nr) & $191(59)$ & $31(48)$ \\
\hline Uncleare (clinscomp_un) & $1(<1)$ & $0(0)$ \\
\hline
\end{tabular}

${ }^{e}$ categories are mutually exclusive

ne except for "Unclear", categories are not mutually exclusive

Table S3.15 Quality of included articles

\begin{tabular}{|l|l|l|l|}
\hline & & $\begin{array}{l}\text { Papers describing patient } \\
\text { decision aid projects }(\mathrm{n}=490)^{*} \\
\mathrm{n}(\%)\end{array}$ & $\begin{array}{l}\text { Papers describing user- } \\
\text { centered design projects } \\
(\mathrm{n}=133)^{\star} \mathrm{n}(\%)\end{array}$ \\
\hline Ethics $^{\text {ne }}$ (ethics) & $362(74)$ & $68(51)$ \\
\hline $\begin{array}{l}\text { Description of the context } \\
\text { (descrcon) }\end{array}$ & & $489(>99)$ & $133(100)$ \\
\hline $\begin{array}{l}\text { Description of the purpose of } \\
\text { the study }\end{array}$ & & $489(>99)$ & $133(100)$ \\
\hline $\begin{array}{l}\text { Experimental evaluation } \\
\text { studies }^{\text {ne }} \text { (studexp) }\end{array}$ & & $276(56)$ & $14(11)$ \\
\hline & $\begin{array}{l}\text { Method of randomization } \\
\text { and/or sequence generation } \\
\text { (descrrand) }\end{array}$ & $214(44)$ & $12(9)$ \\
\hline
\end{tabular}




\begin{tabular}{|c|c|c|c|}
\hline & $\begin{array}{l}\text { Allocation concealment and/or } \\
\text { blinding (descrbind) }\end{array}$ & $156(32)$ & $7(5)$ \\
\hline & $\begin{array}{l}\text { Reported number of dropouts } \\
\text { or complete outcome data } \\
\text { (descrdrop) }\end{array}$ & $213(43)$ & $12(9)$ \\
\hline \multirow{2}{*}{$\begin{array}{l}\text { Non-experimental evaluation } \\
\text { studies }^{\text {ne }} \text { (studeva) }\end{array}$} & & $206(42)$ & $106(80)$ \\
\hline & $\begin{array}{l}\text { Control of potentially } \\
\text { confounding variables } \\
\text { (descrconf) }\end{array}$ & $35(7)$ & $9(7)$ \\
\hline \multirow{5}{*}{$\begin{array}{l}\text { Studies relating to human } \\
\text { participants }^{n e} \text { (studhum) }\end{array}$} & & $484(99)$ & $129(97)$ \\
\hline & $\begin{array}{l}\text { Description of participants } \\
\text { (descrpart) }\end{array}$ & $451(92)$ & $107(80)$ \\
\hline & $\begin{array}{l}\text { Justification of sampling } \\
\text { (descrsamp) }\end{array}$ & $207(42)$ & $56(42)$ \\
\hline & $\begin{array}{l}\text { Description of data collection } \\
\text { and analysis (descrcoll) }\end{array}$ & $478(98)$ & $125(94)$ \\
\hline & $\begin{array}{l}\text { Justification of measurements } \\
\text { (descrmeas) }\end{array}$ & $368(75)$ & $57(43)$ \\
\hline \multirow{3}{*}{$\begin{array}{l}\text { Development studies }{ }^{\text {ne }} \\
\text { (studdev) }\end{array}$} & & $282(58)$ & $103(77)$ \\
\hline & $\begin{array}{l}\text { Description of how } \\
\text { development occured } \\
\text { (descrdev) }\end{array}$ & $243(50)$ & $99(74)$ \\
\hline & Description of how content & $220(45)$ & $93(70)$ \\
\hline
\end{tabular}




\begin{tabular}{|c|c|c|c|}
\hline & $\begin{array}{l}\text { was developed and/or refined } \\
\text { (descrcont) }\end{array}$ & & \\
\hline & $\begin{array}{l}\text { Description of how format was } \\
\text { developed and/or refined } \\
\text { (descrform) }\end{array}$ & $132(27)$ & $78(59)$ \\
\hline & $\begin{array}{l}\text { Description of how data were } \\
\text { used to refine tool (descrref) }\end{array}$ & $158(32)$ & $83(62)$ \\
\hline
\end{tabular}

${ }^{*} n$ for this table is a descriptive overview of all included articles not combined into projects.

${ }^{n e}$ categories are not mutually exclusive. 


\section{Appendix 4. PRISMA 2009 Checklist}

\begin{tabular}{|c|c|c|c|}
\hline Section/topic & $\#$ & Checklist item & $\begin{array}{l}\text { Reported } \\
\text { on page \# }\end{array}$ \\
\hline \multicolumn{4}{|l|}{ TITLE } \\
\hline Title & 1 & Identify the report as a systematic review, meta-analysis, or both. & 1 \\
\hline \multicolumn{4}{|l|}{ ABSTRACT } \\
\hline Structured summary & 2 & $\begin{array}{l}\text { Provide a structured summary including, as applicable: background; objectives; data sources; study eligibility criteria, } \\
\text { participants, and interventions; study appraisal and synthesis methods; results; limitations; conclusions and } \\
\text { implications of key findings; systematic review registration number. }\end{array}$ & 4 \\
\hline \multicolumn{4}{|l|}{ INTRODUCTION } \\
\hline Rationale & 3 & Describe the rationale for the review in the context of what is already known. & 5,6 \\
\hline Objectives & 4 & $\begin{array}{l}\text { Provide an explicit statement of questions being addressed with reference to participants, interventions, comparisons, } \\
\text { outcomes, and study design (PICOS). }\end{array}$ & NA \\
\hline \multicolumn{4}{|l|}{ METHODS } \\
\hline Protocol and registration & 5 & $\begin{array}{l}\text { Indicate if a review protocol exists, if and where it can be accessed (e.g., Web address), and, if available, provide } \\
\text { registration information including registration number. }\end{array}$ & 7 \\
\hline Eligibility criteria & 6 & $\begin{array}{l}\text { Specify study characteristics (e.g., PICOS, length of follow-up) and report characteristics (e.g., years considered, } \\
\text { language, publication status) used as criteria for eligibility, giving rationale. }\end{array}$ & 7 \\
\hline Information sources & 7 & $\begin{array}{l}\text { Describe all information sources (e.g., databases with dates of coverage, contact with study authors to identify } \\
\text { additional studies) in the search and date last searched. }\end{array}$ & $7 \& 8$ \\
\hline Search & 8 & $\begin{array}{l}\text { Present full electronic search strategy for at least one database, including any limits used, such that it could be } \\
\text { repeated. }\end{array}$ & $\begin{array}{l}7 \& \\
\text { Appendix } \\
1\end{array}$ \\
\hline Study selection & 9 & $\begin{array}{l}\text { State the process for selecting studies (i.e., screening, eligibility, included in systematic review, and, if applicable, } \\
\text { included in the meta-analysis). }\end{array}$ & 9 \\
\hline Data collection process & 10 & $\begin{array}{l}\text { Describe method of data extraction from reports (e.g., piloted forms, independently, in duplicate) and any processes } \\
\text { for obtaining and confirming data from investigators. }\end{array}$ & $9-12$ \\
\hline Data items & 11 & $\begin{array}{l}\text { List and define all variables for which data were sought (e.g., PICOS, funding sources) and any assumptions and } \\
\text { simplifications made. }\end{array}$ & 10,11 \\
\hline $\begin{array}{l}\text { Risk of bias in individual } \\
\text { studies }\end{array}$ & 12 & $\begin{array}{l}\text { Describe methods used for assessing risk of bias of individual studies (including specification of whether this was } \\
\text { done at the study or outcome level), and how this information is to be used in any data synthesis. }\end{array}$ & 11 \\
\hline Summary measures & 13 & State the principal summary measures (e.g., risk ratio, difference in means). & 13 \\
\hline Synthesis of results & 14 & $\begin{array}{l}\text { Describe the methods of handling data and combining results of studies, if done, including measures of consistency } \\
\left(e . g ., I^{2}\right) \text { for each meta-analysis. }\end{array}$ & 12 \\
\hline
\end{tabular}




\section{Appendix 4. PRISMA 2009 Checklist}

Page 1 of 2

\begin{tabular}{|c|c|c|c|}
\hline Section/topic & $\#$ & Checklist item & $\begin{array}{l}\text { Reported } \\
\text { on page \# }\end{array}$ \\
\hline Risk of bias across studies & 15 & $\begin{array}{l}\text { Specify any assessment of risk of bias that may affect the cumulative evidence (e.g., publication bias, selective } \\
\text { reporting within studies). }\end{array}$ & NA \\
\hline Additional analyses & 16 & $\begin{array}{l}\text { Describe methods of additional analyses (e.g., sensitivity or subgroup analyses, meta-regression), if done, indicating } \\
\text { which were pre-specified. }\end{array}$ & NA \\
\hline \multicolumn{4}{|l|}{ RESULTS } \\
\hline Study selection & 17 & $\begin{array}{l}\text { Give numbers of studies screened, assessed for eligibility, and included in the review, with reasons for exclusions at } \\
\text { each stage, ideally with a flow diagram. }\end{array}$ & $\begin{array}{l}14, \\
\text { Figure } 2\end{array}$ \\
\hline Study characteristics & 18 & $\begin{array}{l}\text { For each study, present characteristics for which data were extracted (e.g., study size, PICOS, follow-up period) and } \\
\text { provide the citations. }\end{array}$ & NA \\
\hline Risk of bias within studies & 19 & Present data on risk of bias of each study and, if available, any outcome level assessment (see item 12). & NA \\
\hline Results of individual studies & 20 & $\begin{array}{l}\text { For all outcomes considered (benefits or harms), present, for each study: (a) simple summary data for each } \\
\text { intervention group (b) effect estimates and confidence intervals, ideally with a forest plot. }\end{array}$ & $\begin{array}{l}\text { Tables } 3 \\
\& 4\end{array}$ \\
\hline Synthesis of results & 21 & Present results of each meta-analysis done, including confidence intervals and measures of consistency. & NA \\
\hline Risk of bias across studies & 22 & Present results of any assessment of risk of bias across studies (see Item 15). & NA \\
\hline Additional analysis & 23 & Give results of additional analyses, if done (e.g., sensitivity or subgroup analyses, meta-regression [see Item 16]). & NA \\
\hline \multicolumn{4}{|l|}{ DISCUSSION } \\
\hline Summary of evidence & 24 & $\begin{array}{l}\text { Summarize the main findings including the strength of evidence for each main outcome; consider their relevance to } \\
\text { key groups (e.g., healthcare providers, users, and policy makers). }\end{array}$ & $24-27$ \\
\hline Limitations & 25 & $\begin{array}{l}\text { Discuss limitations at study and outcome level (e.g., risk of bias), and at review-level (e.g., incomplete retrieval of } \\
\text { identified research, reporting bias). }\end{array}$ & 27,28 \\
\hline Conclusions & 26 & Provide a general interpretation of the results in the context of other evidence, and implications for future research. & 29 \\
\hline \multicolumn{4}{|l|}{ FUNDING } \\
\hline Funding & 27 & $\begin{array}{l}\text { Describe sources of funding for the systematic review and other support (e.g., supply of data); role of funders for the } \\
\text { systematic review. }\end{array}$ & 30 \\
\hline
\end{tabular}

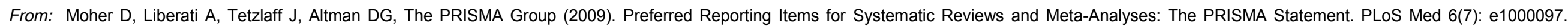
doi:10.1371/journal.pmed1000097 